\title{
Bureaucracy, Democracy and Westminster: The Quest for Political Control
}

\author{
by \\ Jean-Christopher Somers
}

\begin{abstract}
A thesis
submitted to the Victoria University of Wellington in fulfilment of the requirements for the degree of Master of Commerce and Administration in Public Policy
\end{abstract}

School of Government Victoria University of Wellington

2008 


\section{Acknowledgements}

I would like to thank my supervisor, Dr Robert Gregory, without whom this thesis would not have been possible.

I would also like to thank my friends, Dr Stevan Eldred-Grigg and Mr Karl Beckert, for their kind support. 


\begin{abstract}
This thesis argues that a Weberian process of bureaucratisation poses a serious threat in itself to the central values and ideals of liberal democracy. Such a threat arises not only from the bureaucratic pathology of 'goal displacement' of substantive ends by instrumental means, but also, because of this pathology, its tendency to mask and embed ideological challenges to liberal democracy. An effective liberal political constitution is therefore necessary to maintain the democratic control of bureaucracy while exploiting the efficiency benefits of bureaucratic administration. Such a political constitution is in fact contained in the Westminster tradition of liberal constitutionalism, based on the principles of parliamentary sovereignty, ministerial responsibility and political neutrality. Through this theoretical lens, the thesis proceeds to examine the trajectory of public sector reforms against the changing political contexts in New Zealand over the past 20 years and its constitutional implications. The NPM reforms in New Zealand, whether intended or unintended, displaced the political and constitutional safeguards implicit in the traditional model of public service with managerial norms which simultaneously serve to embed the neoliberal ideology. Despite the claim of NPM reformers to control bureaucracy, the paradoxical effects of the reform have been to accelerate the process of bureaucratisation and attenuate democratic control. Recent initiatives aimed to address some apparent weaknesses of NPM, have not changed the fundamentals of the managerial system, and thus fail to reverse this trend of declining democratic control of bureaucratic power. A reassertion of the fundamental norms of the Westminster system is recommended to arrest this decline of liberal democracy.
\end{abstract}




\section{Table of Contents}

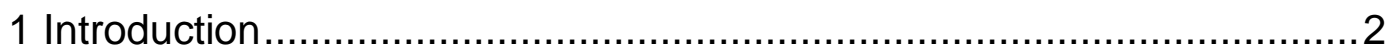

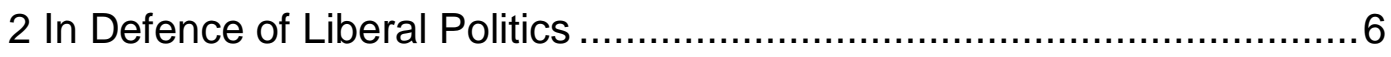

3 Liberal democracy and bureaucracy: Dialogue between Mill and Weber

4 The Political Constitution of Westminster ...........................................31

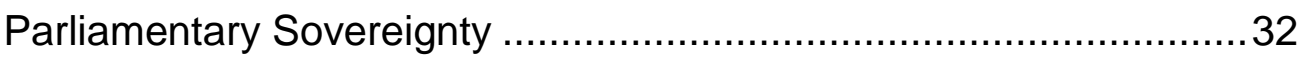

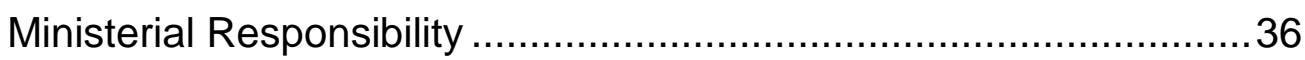

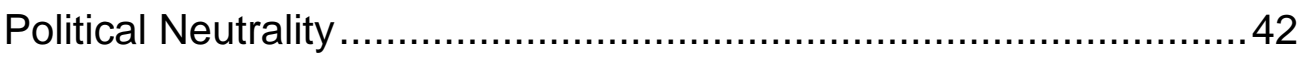

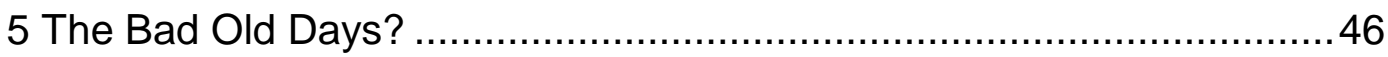

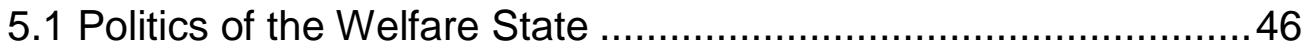

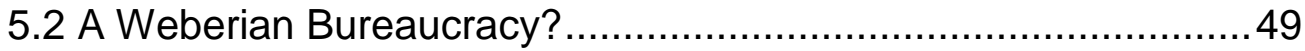

5.3 More Westminster than Westminster?.......................................63

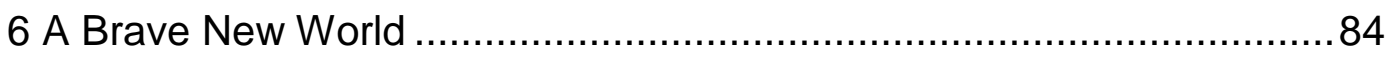

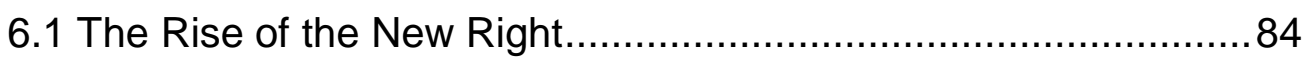

6.2 The New Public Management Model......................................... 88

6.3 From Westminster to Where?..............................................112

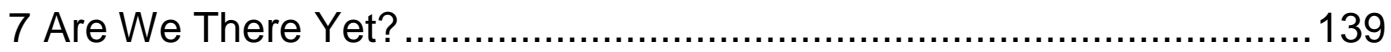

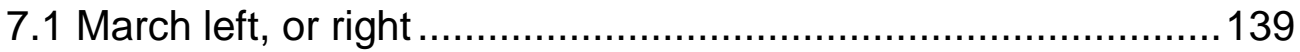

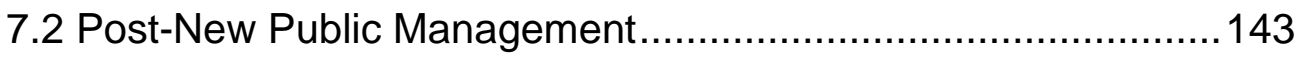

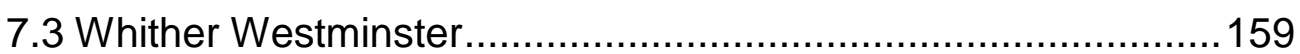

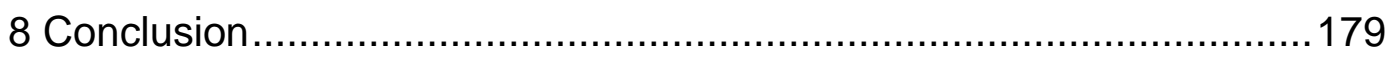

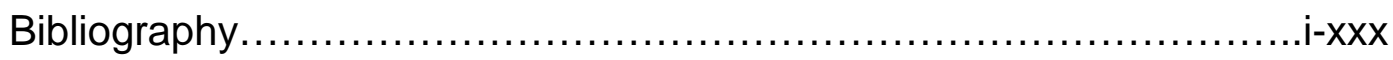




\section{Introduction}

The Public Service in New Zealand has undergone radical reforms during the past few decades. Reforms promise new things: new theories, new technologies, and ultimately new hopes of finding a new solution to the old problem of democratic control over the bureaucracy. Westminster, by contrast, inspires a very different kind of imagination. It is a legacy, which New Zealand inherited more than a century ago. It symbolises continuity and tradition. It seems old.

It is not surprising then that the discontent of public management theorists with Westminster is rising. Some have argued that the commitment to Westminster is the problem (Chapman 2000). Others have questioned whether Westminster is dead in Westminster, or indeed in Wellington (Eichbaum and Shaw 2005b; Rhodes 2005). In 2004, the tension evolved into a minor scandal when the Clerk of the House of Representatives labelled the Public Finance (State Sector Management) Bill ${ }^{1}$, which had been presented as "setting the benchmark of public management" by the Government, a "trojan horse" and "virus-like" (Newberry and Pallot 2004). And yet, a year later, a parliamentary inquiry into New Zealand's existing constitutional arrangements concluded that New Zealand's constitution is "not in crisis" (Constitutional Arrangements Committee 2005).

Crisis or not, it may be time to set aside the "it isn't broke" mentality and look carefully at the tension between public service reforms and the constitutional framework. The aim of this thesis is to try to explore this issue, using an eclectic probing approach, through a broader political perspective. The main questions that this essay seeks to answer are in two parts. Firstly, what is the nature of the relationship between bureaucracy and liberal democracy within a liberal political order, and how does the Westminster system fit into this picture? Secondly, what has

\footnotetext{
${ }^{1}$ The Bill was eventually passed with significant amendments in response to the Clerk's submission, in December 2004.
} 
changed in the bureaucracy as a result of the reforms in the past twenty or so years and what are the implications for New Zealand's Westminster constitutional system?

Politics is key to answering these questions. Public management reforms, as Pollitt and Bouckaert (2004:143) point out, "cannot be adequately comprehended without reference to the crucial relationships between administration and politics, and between administrators and politicians". There is clearly an increasing awareness of the political dimension of public management reform amongst commentators. However, the attempts so far are mainly from the perspective of the public management itself. Politics is still regarded as something beyond "the frontier" (ibid.). Such an approach can yield valuable insights but it also has its limitations. This essay, by contrast, takes politics as a starting point.

In a sense, this thesis is also about "relearning old lessons". As Olsen (2006) argues, it might be time to "rediscover" bureaucracy and its implications for democratic governance. Olsen is referring to Weber's analysis of bureaucracy. This thesis will argue that there is also a need to rediscover the wisdom of political liberalism, J S Mill's theory of bureaucracy and the Westminster system of constitution. Having established this theoretical model, the thesis will turn to the practices of public management and the effects of the reforms on the constitutional framework.

It must be stated that while this thesis draws together a broad range of perspectives, it is not an attempt at a comprehensive theory of liberalism, or bureaucracy, or the Westminster constitution. Rather the objective here is to explore possible arguments about public management from a liberal political perspective. And bearing in mind the challenges of evaluating systemic changes (Boston 2000), neither does it try to evaluate all aspects of the Public Sector reforms over the last twenty years. This thesis is a starting point. 
The thesis is in two parts, organised as follows:

Part I deals with theoretical issues. Chapter 2 outlines a defence of political liberalism, in contrast with communitarianism and libertarianism. It discusses liberalism's fundamental values, its conception of the relationship between the society and the individual, and the centrality of politics within liberalism.

Chapter 3 lays out an analytical model by combining the theories of Max Weber and J S Mill on bureaucracy and seeks to explore the interdependent, yet contradictory, relations between bureaucracy and liberal democracy, against the political-philosophical background outlined in the previous Chapter.

Chapter 4 sets out the Westminster styled political constitution. It discusses the doctrines of parliamentary sovereignty, ministerial responsibility and public service neutrality. It demonstrates that, despite its critics, the political constitution of Westminster is an integral part of the liberal-democratic order and still offers the best constitutional safeguard of democratic control over bureaucracy.

Part II discusses the New Zealand public services reforms and their interactions with and impacts on the constitutional framework. Chapter 5 examines the New Zealand Public Service prior to the reform. It argues that the bureaucratic attributes of the traditional Public Service are paradoxically constrained by the complex and contradictory politics of the Welfare State that underpinned it. Constitutional constraints also played an important role, although their effectiveness was severely limited by a strong majoritarian electoral system.

Chapter 6 looks at the New Public Management reforms in the 1980s and 1990s. It surveys the radical changes made to the traditional New Zealand public service and explains the paradoxical results of "debureaucratisation". It contends that the NPM reforms have made the public 
service more, rather than less, bureaucratic. It is further argued that the NPM reforms, intentionally or unintentionally, had undermined the constitutional constraints on bureaucratic power in crucial areas.

Chapter 7 turns to the incremental changes made to the public services after 1999. While it shows certain changes of the NPM reforms have been reversed, the essential core of the NPM models, and the institutional and political commitment to certain ideas underpinning the NPM model, remains unchanged. This may actually compound the risk of further bureaucratisation, which might get in the way of repairing the damages done to the Westminster system in the past decade.

Chapter 8 provides the concluding arguments. 


\section{In Defence of Liberal Politics}

The relationship between bureaucracy and democracy is doubtlessly political. Indeed, the managerial reforms over the last twenty years are as much a result of changing political ideologies in Western liberal countries as a consequence of different administrative or managerial paradigms. It is necessary therefore to find a firm political foundation on which the discussion can be based.

Liberalism in recent years has come under pressure for some time, firstly from the advent of neoliberalism, and more recently, from the Third Way/Communitarian critiques. But the argument here is that liberalism and liberal politics must be defended, especially given the need for democratic control over bureaucracy.

Central to the liberal ideology is the supreme value of human autonomy the Kantian idea of treating all persons as ends in themselves, not means to some one else's ends, and therefore the demand for equal respect and concern (Kelly 2005; Freeman 2002). In other words, liberals believe that individuals should be free to pursue their own conception of the good life, that is, to make free choices over substantive values, within the limits of justice that ensures the same freedom for others.

Autonomy and equality can be spelled out in more concrete terms as the equality of basic liberties. Liberals differ on what these liberties might be, but for all of them several things are often centrally important, such as, freedom of conscience, speech, movement, and association. These basic rights and liberties often overlap with "civil rights" or what Isaiah Berlin (1969) calls "negative liberty" i.e. freedom from interference of others. Negative liberty has no doubt obtained a special place in contemporary liberal democratic polities. But this does not mean that liberty can be taken for granted, even in its narrow "negative" sense, let alone fully realised. For example, the passing of the Patriot Act in America in response to the September 11 terrorist attacks reminds one that even when these liberties 
are constitutionally enshrined and supposedly sacrosanct, they can still be truncated, rightly or wrongly, for something else (Brown 2003; Dworkin 2006; Haque 2002; Waldron 2003).

Indeed, the "post-September-11" world has brought clearly into focus what has made liberalism attractive in the first place, that is, the reality that there are fundamentally different and potentially conflicting conceptions of what constitutes a good life, as well as what the basic rights are. Liberalism was, after all, born out of religious conflicts and social upheavals. For liberals, this "endemic disagreement" over ends represents a challenge. But it also opens up endless possibilities. For this reason, liberals must embrace plurality of values, which cannot, and should not, be reduced to a single presupposed truth. This is not because, as some alleged, that liberals place the right to choose above every other possible ends. Quite the contrary, it is precisely because these ends are so important intrinsically that, given the context of diversity, it is paramount that one cannot settle on any one version of a good life simply by assumption, and thus preclude or demean many other possibilities. In other words, freedom to choose requires ability to exercise judgments. The priority of autonomy for liberals entails that no goals or ends, whether selfchosen or inherited, should be exempt from critical evaluation by the people themselves (Kymlicka 1989). Thus liberalism does not end with negative liberties. It must also provide for development of individual capacity for critical reflection so that freedom of choice can be meaningfully exercised.

This logic can be extended one step further. The freedom and ability to make choices, as critics of liberalism often point out, are vacuous in themselves because they say nothing about whether these diverse ends of individuals can be achieved in reality (Taylor 1985). Liberalism is empty without "positive liberties". But liberals from Mill to Rawls have never denied the importance of fair distribution of power and resources in order to create basic conditions for human flourishing and in fact have endorsed radical proposals of redistribution (Kymlicka 2001). Liberalism is meant to 
be impartial about the ends that people choose, not indifferent or uncaring. They only point out that the pursuit of positive liberty has inherent risks, because it requires far more complex and ambiguous judgments about both substantive ends and means, which will always be open to debate. Yet, just because of that the stakes are high, there is no reason to shirk responsibility by putting positive liberty in the "too hard" basket. Rather it simply means that caution and vigilance are necessary, so that one is capable of "defending freedom from interference when it ought to be defended" (Gutmann 1996:70).

So instead of a shopping list of pre-determined values, liberalism is better conceptualised as an attempt to construct some common ground on what it means to be human. Liberals aspire to do this without suppressing disagreements through a framework anchored by a shared commitment to autonomy and equality (Kelly 2005; Dagger 2004). This indeterminacy or vagueness does not make liberal values any less "basic" in a sense that they are "fundamental" and "inalienable", which cannot be bargained away for something else (Freeman 2002:109). It is simply a reflection of that fact that they are constitutive parts of the humanity that is itself fluid and diverse.

Despite the superficial connection through the emphasis on negative liberties, libertarians embrace a very different scheme of values. For libertarians, the fundamental value flows from the autonomy of property ownership rather than the autonomy of persons. Indeed, libertarians often construct humanity as "self ownership". Libertarian values thus are not so much about liberty as such, as it is about "protecting and reinforcing absolute property and contract rights", "whatever consequences for individuals' freedom, independence, or interests" (Freeman 2001:133). It is to this value that everything else, and ultimately the moral worth of human beings themselves, can be measured against and therefore inevitably instrumentalised. As a consequence, libertarianism circumvents the liberal commitment to value pluralism and quietly replaces it with a distinctive morality and ethics of entrepreneurialism and "self-care" (Brown 2003; 
2006). In this way, libertarianism has implicitly assumed a particular truth about the good life while depriving other "truths" of their intrinsic worth and recognition. This might help explain why for instance Margaret Thatcher or Ronald Reagan was able to preach both "Victorian" values and individual choices. It is not because they are inherently compatible, but rather the hegemony of the latter over other values, as Wendy Brown (2006) argues, prepares the ground for the authoritarian features of the former.

Communitarianism provides another alternative. While liberal emphasis on autonomy, which leaves open the question of what constitutes the good life, the communitarian value order is explicitly based on certain preconceptions of the good life, consisted of certain "higher, strongly evaluated moral goods", often with an appeal to tradition (Taylor 1989, quoted in Bell 2005). This suggests a strong instrumental vision, which is primarily concerned with the means to achieve pre-given ends. It says nothing about how these ends - the communities worth preserving - are chosen in the first place, on what standards and by whom?

Secondly, because of its emphasis on individual freedom, liberalism is often mistaken for abstract methodological individualism. However, as Kelly (2005) points out, no liberal is required to claim that there is no such thing as society but individuals. Nor must they deny the existence of "public interest" or "the common good". Quite the contrary, liberals have circumvented methodological individualism "by allowing or even insisting that conceptions of individual rights, liberty, and autonomy are of necessity socially constituted" (Beiner 1988:40).

There has always been a recognition of the dialectical nature of concepts such as "society" or "community" or "culture" in liberal philosophy. While these concepts cannot be reduced to their individual parts, they are nonetheless outcomes created by the individuals through their complex 
relations with each other over time, and not reified "things in themselves"2. They may well embody traditions and customs that are "presumptive evidence" of valuable lessons taught by experience, and "as such have a claim to [one's] deference", as Mill has argued (Mill 1962:116). But, to Mill, "intelligent following of custom, or even occasional intelligent deviation from custom, is better than a blind and simple mechanical adhesion to it".

Thus the concept of "society" is actually critical to the liberal ideology, because it constitutes a public realm where autonomy and equal respect among individuals can be realised. The question here is not about the priority of individuals or society, but what sort of society is most compatible with liberal values. And the answer to that is implicit in the parameters governing people's relations with each other. To put it in another way, liberals are concerned about the preservation of autonomy and equality of individuals as social beings.

Implicit in this understanding of the social is an important point: the construction of concepts such as societies and communities are inevitably value-laden. There is an inherent risk when employing such concepts that one forgets the "endemic disagreements" that characterise human relations. To use them as the start and end point of analysis thus runs counter to liberal commitment of value pluralism, because their implicit values too often become the presumed or imposed "truth" under the guise of their "objective" or "organic" existences independent of human beings.

By contrast, libertarianism and communitarianism are both prone to the problem of reification. Libertarian philosophers such as Hayek often criticise liberals for making a category mistake to think of society as a thing in itself. Yet libertarians simply replace one form of reification, which arguably was never endorsed by liberals, with others. The reified universe of libertarianism ultimately boils down to the absolute priority of property

\footnotetext{
${ }^{2}$ The concept of reification is used here to refer to 'the apprehension of human phenomena as if they were things, that is, in non-human and possibly supra human terms' (Berger and Luckmann 1984).
} 
rights, buttressed by the imagery of self-regulating economy or market. For libertarians, property rights is simply a given, the justification of which, as Kelly (2005) argues, invariably falls back on some contestable metaphysical claims about natural law. Against this presumption, liberty becomes formal and secondary. As Narveson (1987:66) claims, "liberty is property...the libertarian thesis is really the thesis that a right to our persons as our property is the sole fundamental right there is". This in turn implies what amounts to the reification of human beings themselves "namely that a person has the moral capacity to make of himself a fungible thing" (Freeman 2001:131). There is no room for human persons as such. This of course is consistent with the dogmatic assumption of singularly "rational self interests" - one might see this as the reification of market rationality - as substitutes for the diversity and complexity of human nature, which underpins a range of technocratic and political theories, such as Public Choice theory. The danger is that such seemingly innocent assumptions become normalised "self-fulfilled prophecies" which may serve to change human beings themselves.

By contrast, liberals recognise that the system of property is socially constructed and therefore must be shaped by its institutional context of the kind of rights, powers, duties and liabilities people have in relation with each other (Freeman 2001). This inevitably entails value choices that cannot be presumed by taking a particular property system for granted. This is why liberals refuse to give property rights absolute priority over other constitutive parts of liberty. Mill notably excludes property rights from his scheme of basic rights and liberties. "There is no place within the liberal conceptual order", Freeman (2001:113) argues, "for the political or legal recognition of people as property or as anything less than persons with basic rights".

In this regard, the rise of communitarianism could be seen as a consequence of, rather than a departure from, libertarianism. The appeal to "the community" as a reified thing in the former serves as a gap-filler for the vacuum created by methodological individualism of the latter. As 
William Outhwaites (2006) observes, there is an underlying connection, a "dialectic", "in which individualism produces its opposite to complement it". Communitarians often talk of "the community", or its traditions and customs, as a given, unquestionably good thing. In comparison, the liberal conception of community is captured by the novelist James Baldwin that it "simply means our endless connection with, and responsibilities for each other" (Baldwin 1986:122). So there are inevitably many different communities, corresponding with many possible values that individuals may share, for whatever reason, with each other and as such have a claim to equal respect. The reification of community then represents a danger that the claims of one particular community might undermine a wider sense of communities and a deeper feeling of belonging. There is a risk that the often conservative and exclusive vocabulary of values offered by communitarians simply becomes a roundabout way to assert the presumptive truth of deeply contestable values (Weeks 1995; 2000). Advocacy for spirit of neighbourhood or traditional family might sound more like apology for gated communities and heterosexual patriarchy - a sort of "white picket fence" nostalgia - rather than genuine attempt at a dialogue, in the eyes of others who have struggled for the recognition of their own communities. This is the crux of the liberalism-communitarianism debate.

Such difficulties have particular resonance for the current popularity of social capital. For Putnam, one of the leading advocates, social capital is equated with reciprocity, trustworthiness and ultimately "civic virtue" (Putnam 2000: 19). Such an assumption of the inherent goodness of social capital typically glosses over not only the complicated sets of social, political, cultural and economic relations of trust and distrusts between people themselves, but also the value judgments that sustain and shape those relationships, which could be either good or bad (Bryson and Mowbray 2005; DeFilippis 2001; Harriss 2001; Mowbray 2005). It says nothing about power, politics and history (Szreter 2002). Indeed for some critics on the left, the concept of social capital is not so much about the "social" as it is about the depoliticised and reified "capital", which serves to 
mask the unequal power relations between the rich and the poor, and the rich communities and the poor communities (Fitzsimons 2000; Fine 2001; Roberts 2004). It does not necessarily mean that social capital theories are simply a variant of capitalism, but clearly one must be wary of the tendency of social capital theories to avoid, rather than confront, old political struggles and conflicts, and their inability to provide any guarantee of freedom and equality for those less privileged.

Finally, the liberal commitment to a value-puralistic society gives rise to the perennial question, namely

How is it possible for there to exist over time a just and stable society of free and equal citizens who still remain profoundly divided by reasonable religious, philosophical and moral doctrines? (Rawls 2005:4)

If people were to live together, clearly there must be some way to resolve the conflicts between their values. Yet this entails "radical choices between rival goods and rival evils" which inevitably involve "loss and sometimes tragedy" for some (Gray 1996 quoted in Spicer 2007). In other words, actually making the choice - as opposed to having the capability and context to do so - necessarily involves the exercise of power. This becomes particularly problematic given the structural inequalities of private power amongst individuals and communities in contemporary societies. There is an inherent risk that the interactions between individuals within unequal power-relations might descend into domination by force. This in turn increases the likelihood of resistance through violence, which further undermines both social justice and stability ${ }^{3}$. Hence there is a need to

\footnotetext{
${ }^{3}$ This is related to the concept of freedom as non-domination. While this idea is often attributed to republican thinkers, it is not exclusively a republican idea. It can be derived directly from liberal values. Clearly liberalism would be practically irrelevant if a large section of society are vulnerable to coercion by others. Liberals, like republicans, recognise power imbalance itself as a threat to liberty. J S Mill, for instance, argues that the state should keep a vigilant control over one's exercise of power over others, and accordingly argues for state intervention in family, prima facie, given the power imbalance between parents and children (Mill 1974).
} 
control the exercise of power and to secure its legitimacy, especially for the disadvantaged ${ }^{4}$.

For liberals the solution to this problem lies in "the primacy of politics". The concept of politics, in its liberal democratic sense, is simply the commitment to make collective decisions through compromise and conciliation, without resorting to outright coercion or undue violence (Crick 2005; Stoker 2006). It implies, Crick (2005:4) argues, "at least some tolerance of differing truths". This is somewhat an understatement of what makes politics particularly attractive from a liberal perspective. "Politics does not settle things", as Elizabeth Frazer (2007:256) argues. Instead of dismissing opposition by appeal to a final authoritative truth, it offers full acknowledgement of the loss and disadvantage while insisting on the "openness" of political process so that whatever decisions reached "are always revisitable and always will be revisited" (ibid.). In this way a pluralistic society is reconciled by the need for collective decisions or desires for the common good.

This does not mean that anything goes in liberal politics. While liberal politics does not require people to make particular judgements or decisions, it does require constraints on how such decisions are made. In other words, liberal politics is concerned with controlling, as Frazer (2007:255) puts it, "the power to decide how we are going to decide". This is where democracy comes in. It makes the exercise of power public, and subjects it to public authority. Here liberal democracy can be seen as an institutional safeguard of fundamental liberal values. It takes as its starting point the liberal values of autonomy and equality between citizens as decision makers, and institutionalises this principle in the form of formal equality of votes. This in turn ensures that all citizens have a voice in political discussion and decision-making, and hence a share of political

\footnotetext{
${ }^{4}$ Legitimacy is of course a slippery term. There are different kinds of legitimacy. Max Weber for instance, argues that there are three forms of legitimacy, based on different types of authority: charismatic, traditional and legal rational. But for liberals such as $\mathrm{J} \mathrm{S}$ Mill, legitimacy in a liberal society means far more than merely allowed by law; it depends on 'the consent and authorization of the people' themselves (Baum 2000:96)
} 
power. Democracy, as Stoker (2006:9) points out, delivers at a very basic level: "it cannot guarantee you a happy life, but it makes government and power-holders in society inclined to look after your basic necessities". Influence in turn provides scope for action. On one hand, the formal political equality between citizens as decision makers makes it possible for those disadvantaged to challenge the deeply entrenched social and economic inequalities, rather than being forced to accept the definition of "equality" or "equity" of those already privileged. Of course, this implies that social or economic privileges should not automatically translate into political inequality and dictate political deliberation. On the other hand, liberals such as Mill and Rawls put a high premium on the educative role of democracy (Wolff 1998; Zakaras 2007). They believe that political participation through voting and other political activities will help people become better, more critical citizens. In doing so citizens can empower themselves. Thus, although democracy does not always lead to good decisions, over time people will learn to be good judges of ends of their own and of others themselves. Therefore liberal democratic politics is "what makes us free" (Tomkins 2002), both in relation to others and to people themselves ${ }^{5}$.

Politics provides no easy solution to settle conflicts of values. But if the society is serious about respecting people as moral equals and about the values they hold, the resolution of conflicts between them must be done the hard way, by people themselves.

It is not surprising then that both libertarianism and communitarianism exhibit certain aversion of politics - that is not to say that they are not themselves political - as a way to legitimise the exercise of power. They both begin by denying the diversity and conflicts of values. And there can be no politics without conflict. Libertarians do this by reducing complex social and political relations between individuals to presumably voluntary

\footnotetext{
${ }^{5}$ It must be pointed out that Tomkins specifically links this view to republicanism of Philip Pettit and Hannah Arendt. But it is not difficult to derive the essential values of democratic politics from a liberal point of view.
} 
economic transactions between economically rational and self-interested agents. As Freeman (2001) argues, the liberal conception of political power bears a striking resemblance to feudalism where political power is exercised privately for private ends. Freeman, however, overlooks an additional connection between feudalism and libertarianism, that is, both seek to legitimise the exercise of power by referring to taken-for-granted regimes of truth, rather than political reason. Divine authority and the invisible hand of the market serve a similar function to justify inequalities and dominance, which cannot be justified amongst human beings themselves.

The absence of politics and struggle is also evident in communitarianism and its social capital variant in community (Navarro 2002). The communitarian rhetoric of the "natural" or the "organic" characteristics of the communities promotes, in Brent (2004:218)'s words, "a depoliticizing myth by which social inequality becomes natural difference" because such rhetoric obscures the fact that the supposedly "natural" facets of humanity are always "riddled with and constituted through power". Unsurprisingly, orthodox communitarian thinkers, as Adrian Little (2002:154) observers, see politics as "something to be overcome to the greatest possible extent". For them the decision-making process ought to be driven by an apolitical morality rather than representative democracy.

The argument here is that liberalism provides the best guarantee that individuals in a value-pluralistic society can nevertheless live together and resolve their conflicts through participation in politics, without sacrificing their claims to autonomy and equal respect to the false gods of the market, or the community, or something else.

Of course, liberalism is more than a philosophical idea. It is also a system of social and political institutions, such as democracy, Parliament, free press and many others. These two concepts of liberalism are interdependent: liberal values and beliefs shape the liberal institutions. Conversely how these institutions are designed and run determines 
whether the promise of liberalism can be delivered. So what then is the place of bureaucracy within the liberal democratic institutional order? 


\section{Liberal democracy and bureaucracy: Dialogue between Mill and Weber}

There is no easy fit between bureaucracy and liberal democracy. But as Paul du Gay $(2000 ; 2004)$ argues, an abstract celebration or denunciation of "bureaucracy" would make little sense, as there are many different kinds of bureaucratic organisations. Nonetheless, it is possible to identify certain characteristics that make organisations "bureaucratic" and possibly problematic, based on which one can then conceptualise different bureaucratic organisations and differing degrees of compatibility with liberal democracy. Weber's theory of bureaucracy as an "ideal type" thus provides an important tool to understand bureaucracy.

As Warner (2001) argues, the Weberian account can be usefully supplemented by that of J S Mill, which is clearest in his essay, Consideration on Representative Government. One reason for the utility of Mill's theory is that Mill explicitly posits bureaucracy within representative government. This enables Mill to connect his account directly with liberal political philosophy, while Weber's account is mainly analytical and descriptive. Mill's theory is fundamentally concerned with how the relationship between democracy and bureaucracy can be configured to reduce the danger of bureaucratisation, while Weber, as Campbell and Peters (1988:80) comment, might be seen as "attempting to protect the State from the excess of politicians".

A useful starting point would be the meaning of bureaucracy. Here the Weberian theory becomes slightly fuzzy, as Weber never explicitly defined bureaucracy, at least in its general sense (Albrow 1970). Nonetheless, Weber's specific concept of modern bureaucracy can be understood by reference to his idea of "legal-rational" authority. Here modern bureaucracy is characterised by its increasingly "rational" orientation, that is, it derives political authority from adherence to law or other explicit formal rules, which in turn is based on formal knowledge (Weber 1978). Weber's conception of bureaucracy is highly legalistic, which reflects the 
Rechtstaat tradition of continental Europe (Lynn 2006). This partly explains the differences between Mill's and Weber's theory of bureaucracy. Rather than taking the abstract concept of law and enlightened knowledge as a starting point, Mill goes directly after those who control them. Thus, "the essence and meaning of bureaucracy" for Mill is that "the work of government has been in the hands of governors by profession" (1962: 245). In doing so Mill circumvents the reified myth of legal authority: after all, law is not a thing in itself. Nonetheless Mill shares Weber's emphasis on knowledge. It is the claim to professional knowledge, rather than adherence to rules as such, that underlines professional and bureaucratic power. The relationship between bureaucracy and democracy therefore can be understood as a balance between technical competence and political participation.

In this light it is easy to see why, despite their contradictions, bureaucracy and liberal democracy need each other, a point which is often lost in the single-minded attacks on the alleged bureaucratic inefficiency. Bureaucratic knowledge provides the instrumental means for whatever the substantive ends chosen through the political process. In Weber's word, "the fully developed bureaucratic mechanism compares with other organisations exactly as does the machine with the non-mechanical modes of production. Precision, speed, unambiguity, knowledge of the files, continuity, discretion, unity, strict subordination, reduction of friction and of material and personal costs - these are raised to the optimum point in a strictly bureaucratic administration" (Weber 1978:214). While bureaucratic organisations may not necessarily possess the "technical superiority" or "efficiency" as Weber envisages - a point which will be discussed further below - without bureaucracy of one form or another, modernity would have been impossible because of the enormous demand on society, economy and the state. However bureaucracy also serves an important substantive purpose within the liberal democratic order. As du Gay (2000:76) argues, the formal rationality of bureaucracy is "not consequent with the development of an attitude of amoral instrumentalism, but on the cultivation of a liberal-pluralist ethics of responsibility which 
does take into account the consequences of attempting to realize the essentially contextable values that frequently come into conflict with other values". In other words, the bureaucratic ethos of impersonality without "regard to persons" can be regarded as an expression of liberal impartiality between values. Thus Weber has good reason to insist that "the choice is only that between bureaucracy and dilettantism" (1978:223).

Mill is certainly not blind to the benefits of bureaucracy. In Mill's view, bureaucracy and democracy can and must be complementary. "Government by trained officials cannot do, for a country, the things which can be done by a free government; but it might be supposed capable of doing some things which free government cannot do" (Mill 1962:247). However a subtle but nonetheless important difference that sets Mill and Weber apart, is that Mill is clear that the benefits of bureaucracy must be measured against the fundamental value of freedom. Without bureaucratic means, Mill argues, "freedom cannot produce its best effects and often breaks down together". It is because the fundamental importance of freedom that bureaucracy is essential. Yet, it is a matter of principle that "there cannot be a moment's hesitation between representative government... and the most perfect imaginable bureaucracy" (ibid.). For bureaucracy, as Mill sees it, poses fundamental challenges to liberal values.

Firstly, there are potential conflicts between bureaucratic and liberal values. But first of all one must be clear about what exactly the values of bureaucracy are. One potential candidate is "efficiency". Yet, the notion that bureaucratic organisations are "efficient", which had been mistakenly attributed to Weber (Gregory 2007a), seems almost incomprehensible, especially against the popular image of bureaucratic inertia and red tape. This does not mean that one must abandon Weber's account, however. The problem, some argue, is that something has been lost in translation (Gajdunshek 2003). As Albrow (1970) argues, the Weberian concept of bureaucracy is based more on the idea of rationality, rather than efficiency. Arguments over whether or not bureaucracy is efficient, or whether it could 
be made more efficient, are no doubt important, but they miss the point. Efficiency, after all, is in the eye of the beholder. In its basic sense as employment of means to achieve a given ends, it simply evokes the uncertainty and complexity of defining the ends in the first place ${ }^{6}$.

So that bureaucracy is "inefficient" does not make bureaucracy less attractive or less bureaucratic. (Conversely making bureaucracy more efficient does not make it less bureaucratic.) It simply means there are disagreements over the bureaucratic definition of efficiency. Yet this is precisely where the central value of bureaucracy lies. What it offers is not "efficiency" as such, but rather, as an alternative to democracy, fewer disagreements. Bureaucracy is in one sense "simply the way of transforming social actions into rational actions" (Gregory 2007a:226). Appeals to reason, or rationality, are supposed to settle argument and thus reduce uncertainty. It is in this sense that Weber links rationality with efficiency (Gajduschek 2003; Hummel 1994).

This concept of bureaucracy can be understood through the lens of instrumental and substantive rationality (or Zweckrationalitat and Wertrationalitat). The former is primarily concerned with the "objective" selection of best means towards given ends, whatever those ends might be. The latter by contrast relates to substantive choices between values, which are ends in themselves and not means to some other ends (Brubaker 1984). For Weber, instrumental rationality defines bureaucratic expertise, while substantive rationality characterises democratic politics.

This conception makes plain the tension between the bureaucratic virtue of uncertainty reduction and the democratic freedom of plurality of values.

\footnotetext{
${ }^{6}$ The libertarian thinker, Murray Rothbard, has argued that 'social efficiency is a meaningless concept because efficiency is how effectively one employs means to reach given ends. But with more than one individual, who determines the ends toward which the means are to be employed? The ends of different individuals are bound to conflict, making any added or weighted concept of social efficiency absurd' (Rothbard 1982: n.8). Yet, as a libertarian, he would have denied that individuals' ends are in fact socially chosen and that efficiency is inevitably social. Another interpretation would be to recognise that all these different possibilities of 'efficiency' are equally valid.
} 
The instrumentally rational bureaucracy is vulnerable to the problem of "goal displacement" (Blau 1955; Bohte and Meier 2000; Merton 1968). In bureaucratic organisations, means have a tendency to become ends in themselves, which, as Gregory (2007a: 226) argues, is "not so much a form of bureaucratic irrationality as a paradox inherent in all large organisations". That paradox, in Weberian terms, is the domination of instrumental rationality over substantive rationality. But the real danger of "goal domination" is not that bureaucratic instrumentality creates a moral or ethical vacuum, or that it displaces certain valuable ends (there would inevitably be disagreements over what those ends actually are, at any rate). Rather, it provides no robust public process for debates or deliberation about the chosen ends.

In other words, the outcome of "goal displacement" - there might be legitimate reason for reconstructing some means as ends, or vice versa and in any case the means/ends dichotomy is a false one - is less important than the process by which this happens. Goal displacement is not so much a result of intentional capture, or "corruption" by political interests, but rather it arises out of the separation between bureaucratic and political processes of decision-making, or the politics/administration dichotomy. There is a risk that the instrumentality becomes an easy excuse for arriving at value judgements that would not stand the scrutiny of the democratic process (Turner 1994). Philip Selznick similarly highlights the risk that political purposes could be subverted by pragmatic organisational responses to local political imperatives, in his work on Tennessee Valley Authority (TVA) (Selznick 1949; Gregory 2007a). J Q Wilson (1989:73), by contrast, argues that what happens to TVA is a result of "law, experience and professional norms" rather than "sinister private interest". There is no necessary conflict between these two explanations ${ }^{7}$. The point is that, when decisions are made purely on instrumental considerations, some substantive ends must be presumed to be true or

\footnotetext{
${ }^{7}$ It could be argued that Wilson's explanation is predicated on a false dichotomy. After all law, experience and professional norms are themselves shaped by different interests, not limited to professions' own.
} 
worthwhile of pursuing, whatever they are. Wilson does make the point that focusing solely on particular "sinister" interests will not solve the problem of goal displacement. Even if it succeeds in eliminating one interest, there are many others.

The emphasis on uncertainty reduction through instrumental reason is related to the second problem. That is, the dehumanising effects of bureaucracy. The subjectivity and caprice of human beings, and the complexity of their social interaction with each other, obviously run counter to this desire. Weber explains that

[Bureaucracy] develops the more perfectly, the more it is 'dehumanised', the more it succeeds in eliminating from official business love, hatred, and all purely personal, irrational and emotional elements which escape calculation. This is the specific nature of bureaucracy and it is appraised as its special virtue (Weber 1947:216).

Interestingly, both Weber and later Hummel note that this dehumanising effect is consistent with the need of a capitalist market economy in which the predictability of potential customers is a prerequisite of modern mass production (Weber 1947: 215; Hummel 1994).

The conventional charge of dehumanisation against bureaucracy is that it reifies the relations between human beings (between bureaucrats and citizens, and amongst citizens themselves) as if "things in themselves". If bureaucracy is conceived as a legal rational authority (rather than, say, "governors by profession"), then reification seems unavoidable. "In administering the law, how can a bureaucrat avoid reifying the law", asks Farmer (1995:35). The bureaucracy as an embodiment of the law and reason, stands as foreign objects towards human beings and demands their obedience, while the human architects of these social structures those who control the bureaucracy and those who make law - remain hidden in the background. Bureaucracy, in Hannah Arendt's words, is the 
"rule of nobody" (Arendt 1963). This "unavoidable" reification in turn fragments the full personhood of individuals and reduces them to impersonal "cases" to be administered "without regard to persons", and simultaneously transforms bureaucrats themselves into "cogs in a machine" supposedly without their own moral agency. Of course reified things are, in the end, myths. But they are powerful myths that act on human consciousness and thus can have very real consequences, as exemplified by the actions of bureaucrats in the Nazi regime.

This conventional view has been challenged by Paul du Gay (2000), who attempts to justify the bureaucratic capacity to treat individuals as cases on the basis of the liberal-pluralist ethics of equality. But du Gay appears to have overlooked the qualitative differences between the impartiality of bureaucracies within a liberal democracy and the impersonality of a Weberian legal-rational bureaucracy. These two are superficially similar, just as the "equality" between customers is superficially similar to equality between citizens. It is simply not necessary to truncate one's humanity in order to gain equality. And indeed "to treat individuals as cases, apart from status and ascription", as du Gay (2000:42) prescribes, by definition fails to treat all individuals as equals with inherent rights to challenge their unequal status and ascriptions. It says nothing about how these "cases" are to be treated by bureaucrats and by other individuals.

However, this side issue does allude to the central fact that, as Russell and Gregory (2007:343) argue, that "legal rational authority... is always conditional and not absolute". However, the problem is precisely that the reification of bureaucratic relations tends to disguise its conditionality that limits on how far one can really treat people as "cases".

Finally, Weber is clearly concerned about the displacement of democratic politics as a result of bureaucratisation. The very nature of a Weberian bureaucracy makes it inimical to the democratic process. Weber stresses the fact 'that 'democracy' as such is opposed to the 'rule' of bureaucracy, 
in spite and perhaps because of its unavoidable yet unintended promotion of bureaucratisation" (1947:231).

Weber is pessimistic about the prospect of democracy in the struggle for power and control. He believes that

the power position of a fully developed bureaucracy is always overtowering. The 'political master' finds himself in the position of the 'dilettante' who stands opposite the 'expert', facing the trained officials who stand within the management of administration (Weber 1947:232).

The appeal to "objective" expertise of law (or economics) is hard to resist, compared to the messy, "irrational" and inconclusive process of political compromise and conciliation. Indeed, the very need for political compromise is marginalised by the imperative of control. Control demands mastery of all things by calculation, including taking control of other human beings. Such inherent tension underlines the two folded dangers of bureaucracy vis-à-vis politics, according to Hummel (1994:227). On one hand, "bureaucracy creates the illusion that all problems, including political ones, can be translated into administrative and technical ones". On the other, "bureaucracy produces a truncated politics that itself rests on bureaucratic assumptions, thereby obscuring the possibility of a full human politics". What has been lost in translation however is something fundamental to democratic legitimacy, that is, people should have at least a voice and a share of power in making decisions about their own ends.

For Weber, the threat of bureaucratic domination, especially for democracy, also comes from a particular source. For Weber, "the concept of 'official secret' is the specific invention of bureaucracy, and nothing is so fanatically defended by the bureaucracy as this attitude" (Weber 1947:233234). Despite a gradually spreading culture of openness, today's society in fact makes the construction of "secrecy" much easier, rather than harder, than ever before. It is the increasing amount, and complexity of formal 
knowledge, rather than the crude and untenable insistence on official confidentiality, that constitutes a barrier to knowledge. It does not mean that confidentiality has necessarily declined in importance: it still persists in the name of legal and commercial privilege, intellectual property, and even old-fashioned national interest. This deals a fatal blow to democratic politics. Without information to talk about, political discourse is bound to be constrained. Moreover, ignorance of citizens and their representatives naturally increases the prestige of experts and reinforces their grip of power.

Weber refers to bureaucratic domination as the "stahlhartes Gehause". As Peter Baehr (2001) argues, this is more accurately translated as "shell as hard as steel", rather than "iron cage". The former better reflects Weber's concern that modernity may have come to produce a new kind of human being, who is not merely constrained in their otherwise intact power, but actually disempowered. Hannah Arendt voices similar concerns that bureaucratic organisations can socialise people to see themselves "not as actors but as those acted upon" (May 1996:70). Yet, if one were to believe that where there is power there is resistance, the more complete the domination might appear, the higher risk that it might lead to catastrophic collapse.

Mill's diagnosis of the danger of bureaucracy bears striking similarity to Weber's. He is aware of the tension between bureaucratic rationality and value pluralism. Bureaucracy tends to become routines, but "whatever becomes of routines loses its vital principle" (Mill 1962: 167). Equally Mill understands perfectly the dehumanising tendency of bureaucracy, when he argues that "the more perfect that organisation is in itself...the more complete is the bondage of all" (1962: 167). And finally, Mill is similarly concerned that the rise of bureaucratic power might mean that "nothing to which the bureaucracy is really adverse to can be done at all" (1962: 246). However Mill and Weber differ significantly on the solutions. Unlike Weber, Mill is optimistic about the ability of "a popular government to enable conceptions of man of original genius to prevail over the obstructive spirit 
of trained mediocrity". Perhaps what makes it easier, or more natural, for Mill is that his conception of bureaucracy is embedded in his construction of liberalism, which enables him to fold the problem of bureaucracy into a general political perspective. From this vantage point, the tensions between bureaucracy and democracy mirror the paradoxes inherent in liberal political philosophy itself, namely between value pluralism and particular "truths", between individuals and society, and between politics of compromise and control by expertise. Thus paradoxically the antidote to bureaucratic ills lies in the vitality of the democratic polity itself.

Perhaps the most ingenious aspect of Mill's scheme of balancing bureaucracy and democracy is that Mill does not seek to "control" bureaucracy, but rather to reassert the primacy of politics over it. This point holds key to understanding how Mill's approach will work.

At the heart of Mill's scheme is that the final decision making power should remain in the hands of the people. The people must be "masters, whenever they please, over all operations of government". There is a need, Mill acknowledges, "to secure to the representative body the control over everything in the last resort" (Mill 1962: 228-229). In other words, political sovereignty must reside with the representative body, which makes it clear that bureaucracy cannot be a power in its own right. Thus while Mill distinguishes between functions of "government by trained officials" and "free government", he does not envisage a demarcation between politics and administration. It follows then while the representative body needs to delegate its power, it must nonetheless have "the final seal of national assent", which gives it the necessary leverage of actual power.

But perhaps more importantly Mill envisages the representative body as a political constraint on bureaucracy

to throw the light of publicity on its acts: to compel a full exposition and justification of all of them which any one considers questionable; to censure them if found condemnable, and, if the men who compose 
the government abuse their trust, or fulfil it in a manner which conflicts with the deliberate sense of the nation, to expel them from office, and either expressly or virtually appoint their successors (1962:239).

This is not simply the cliché that "sunlight is the best disinfectant". Rather the emphasis on publicity is to secure "unlimited latitude of suggestion and criticism", which may well confuse rather than clarify, and yet is intrinsically valuable because it brings the diversity of values to bear on bureaucratic acts. The point is not to increase "transparency" as such, but rather to problematise the certainty and predictability and to expose expert opinions to non-expert value judgements. Here Mill appeals to "the ideal of liberalism to defuse the claims of the knowledgeable" (Currie and Musgrave 1985:93). Mill requires the less knowledgeable should be "led with their eyes open and give the best assent they can, unforcedly, freely and on the basis of such information and argument as they can be given". But it is precisely because people are not experts, and without a presumed frame of mind, that there is a range of choice which enables one to recognise the wise and noble amongst us (Ryan 1974). Here representativeness provides a countervailing influence against bureaucratic norms.

Implicitly, in this notion is also an affirmation of the essentially human nature of the relations between bureaucrats, and the people and their representatives. The authority of bureaucrats to lead ultimately depends not on their claim to the impersonal authority of superior knowledge, but rather on them being able to obtain the interpersonal trust from the people, which can be removed by people themselves. Power held on trust is not given unconditionally. It depends critically on those who are in positions of power to exercise such trust responsibly. Such responsibility is thus broad rather than specific. It does not require, and indeed is not dependent on knowledge of the technical details. Instead it requires the experts to justify their actions to those who do not have such knowledge and to satisfy 
whatever questions they might have. This helps to correct the inherent imbalance of power between experts and non-experts.

Finally, Mill emphasises the most important role for the representative body is not to do, but to talk, and to ensure as diverse and wide a range of voices as possible. Mill urges his readers to value the deliberative capacity of the representative body and criticises those who dismiss it as mere talks:

A place where every interest and shade of opinion in the country can have its cause even passionately pleaded, in the face of the government and of all other interests and opinions, can compel them to listen, and either comply, or state clearly why they do not, is in itself, if it answered no other purpose, one of the most important political institutions that can exist any where, and one of the foremost benefits of free government (1962:107).

And in doing so, he highlights the centrality of politics in testing competing versions of "truths" through "reconciling and combining oppositions... by a rough process of struggle between combatants fighting under hostile banners" (ibid.). The emphasis on talk reflects the priority on democratic legitimacy. For Mill it is essential talk must precede doing, for it is necessary to convince the people first through dialogue in order to secure their trust. Here lies the power of talking, even if talking will not directly stop "doing". There are intrinsic values in dialogue, as Mill argues, and by insisting on it one resists the bureaucratisation of politics. Moreover, Mill believes that dialogue might bring more fundamental changes, as "it is what men think determines how they act". Changing hearts and minds is the unique ability of politics, one which the representative body actually has a leverage over bureaucracy.

The brilliance of Mill's scheme is that it brings out the essential features of humanity: the ability to talk, to listen, to judge, to deliberate and to trust and makes it the final word on bureaucratic action. The logic is simple: it is 
futile to control the bureaucracy by inventing ever more sophisticated controls, which will only make it even more "bureaucratic". Rather it is by actually practising humanity - that is by actively engaging in politics - that it can be saved from bureaucratisation. 


\section{The Political Constitution of Westminster}

Mill's idea of balancing bureaucracy within democracy sets out the guiding principle for a liberal democratic institutional order. Constitutions in turn give concrete shape and practical expression to this institutional order. Conversely, the justification for certain constitutional principles or norms can be found in the political argument as laid out above. Here constitutions are, like "bureaucracy", Weberian "ideal-types". Constitutions in reality never neatly fit with whatever political theorists might expect of them. But it nonetheless tells one how well the fit is, and why certain things, however they come into being, must be defended and strengthened if one is to uphold the ideals of liberal democracy.

Unsurprisingly, there are different approaches to constitutions. A conventional view is that constitutions are attempts to limit government by law and based the legitimacy of government action on that law. Such a concept, which can loosely be called legal constitutionalism, is familiar to continental Europeans and Americans, as well as constitutional lawyers. However, the Westminster constitutional system, which is most relevant to New Zealand, belongs to a quite different tradition. It seeks to ground constitutions in the supremacy of politics rather than law (Bellamy 2007; Griffith 1979, 2000; Tomkins 2002, 2005). This as will be shown below is the rationale underpinning the characteristics of Westminster norms of parliamentary sovereignty, ministerial responsibility and civil service neutrality ${ }^{8}$. And it explains why the Westminster constitution is liberal in character and why these essential principles should not be undermined.

Particular attention will be paid to its implication for democratic control of bureaucracy. This is not difficult. While the debates are often framed in legal terms, it can easily be seen as a particular example of the struggle for supremacy between what is essentially a legal-rational authority

\footnotetext{
${ }^{8}$ This is, of course, a simplified description of the Westminster system, to which one can add numerous others (Rhodes and Weller 2005). Nonetheless, these three are amongst the core components of the Westminster constitution, and are the most directly relevant for the purpose here.
} 
composed of legal experts - Weber and Mill's conception of bureaucracy on one hand, and the politicians and people on the other.

\section{Parliamentary Sovereignty}

At the heart of the Westminster system is the doctrine of parliamentary sovereignty. The doctrine, according to Albert Dicey, simply means the ability of Parliament "to make or unmake any law whatsoever", and no person or body has the right to override or set aside legislation of Parliament (Dicey 1915:34-35). But this textbook definition, by stressing legal supremacy, is actually misleading, because the legal process where disputes are brought to definitive settlements by an ultimate judicial authority is very different from a political one (Gordon 1999:52). Perhaps the most critical difference is that the legal doctrine of sovereignty requires assuming "the law" as the authoritative source of truth - hence the possibility of definitive settlements and the need for an ultimate authority while the political process is contingent on the rejection of such a notion and the reification that almost inevitably comes with it. Indeed, there is very little one can say to justify parliamentary sovereignty in this sense. Parliament is not particularly good at doing what lawyers are trained to do, and as Mill would have argued, should not have tried in the first place.

Rather, the definition and justification for the doctrine is and must be a political one. In fact, this is evident in the historical origin of the doctrine, which evolved out of the bitter and sometimes bloody struggle between Parliament and the Crown in 17th Century Britain (Goldsworthy 1999; Tomkins $2001 ;$ 2005). What is at stake is not the control of legislation as such, but the control of political power. And the achievement of the $17^{\text {th }}$ Century constitutional settlement is that Parliament's political authority prevails over the divine authority of the Crown.

This means the debates can be reframed. The charge against parliamentary sovereignty often claims that it provides insufficient safeguards for certain values such as basic human rights. The implicit 
assumption is that there is an "objective order of values", whatever that might be, the denial of which is by definition tyranny. No doubt, an argument can be made that good government, or efficient administration, is part of this indisputable, or rather undebatable, objective order of values, and therefore should be insulated from parliamentary power. This might seem simple to lawyers, but it will not do in a liberal pluralist polity. For the interpretations and enforcement of such fundamental values, and indeed the construction of values in the first place, are themselves acts of power, given the possibility of many other alternative conflicting interpretations.

In this context "sovereignty" means the final say on the conflicts between rival values. And the reason Parliament must be politically sovereign is not because it is the most effective way to realise certain fundamental values, but rather it "best gives effects to the principle of popular sovereignty, whereby people in a self-governing community are empowered" (Ewing quoted in Bradley 2004:57). This in turn flows from the fact that, as Mulgan (1997b:99) puts it, Parliament is still

the only institution of the central state whose members are chosen by the people. It is the only forum in which the members of the political executive are regularly obliged to answer for their actions.

One might add that it is the only place where bureaucratic organisations are subject to scrutiny and compelled to obtain assent from the people for its powers. Moreover, no other institutions give the formal acknowledgement of citizens as equals, as parliamentary democracy does, through fair and regular elections and through open access to its process. Of course, such a process is far from perfect. The quality of elective process necessarily determines the degree of representativeness of Parliament and its claim to power. But it is still far better to live with an "elective dictatorship", as Lord Halisham calls it, than an unelected dictatorship. 
The political doctrine of parliamentary sovereignty eschews the difficulties with the legal doctrine. Rather than creating a Hobbesian "sovereign" power, it ensures that political power is ultimately subjected to political constraints through the parliamentary and democratic process in which all citizens have an equal right to participate. It makes certain that whatever decisions made will always be open to challenges and that the society is not stuck with a particular version of basic values or fundamental rights passed down by those already powerful. In doing so, it acknowledges that no value judgements are free of mistakes and caveats, and preserves the possibility and scope for political actions and redresses. Certainty is not a virtue in this process, however desirable it may seem. And the lack of it underlines the reason why legal administrative or economic bureaucracies are absolutely necessary. However, to quote Griffith (2000:165), "if we are to create a more just and a more free society, we must do it the hard way - without Moses".

How then can Parliament fulfil its constitutional role? Legislative power is important. So is the control of public finance. Both affirm that the ultimate control remain with Parliament and provide means through which it can be exercised. And both have a symbolic importance in Westminster constitutional history. But, for all the arguments that Parliament should be more "assertive" in its legislative or financial functions, it would be useful to be reminded that, to quote Mill, these are "instruments of political warfare, which no one desires to see used but no one likes to part with" (1962:239). They are more useful in crises than in a healthy polity. Thus the dilemma for Parliament is that it seems to have few usable and effective powers.

This does not have to be the case, as Tomkins argues. Rather than adhering to the late Victorian invention of Parliament's function as a legislator, one should instead focus on its more enduring and, in the long term, more promising role as a scrutiniser of government (Tomkins 2003a; 2003b). In fact, everything that Parliament does potentially gives it the opportunity to probe and criticise the action of Government (McGee 2005:4). The question, therefore, is how to make scrutiny more effective, 
which as a deliberative forum Parliament is actually good at, rather than competing for direct control with the Executive. Here lies Parliament's real power over the Executive, as Bernard Crick (1964: 80-81) once remarks, in "influence not direct power; advice not command; intrusion, not obstruction; scrutiny, not initiation; and publicity not secrecy". And it is the role consistent with what Mill envisaged for this representative forum.

Parliament's legislative and financial control functions are actually important parts of this scrutiny role (Tomkins 2003a). The provide windows of opportunities for Parliament to scrutinise government policies and operation beyond the particular bill or estimate. Parliament has other opportunities available, particularly through the select committee systems which have become increasingly important in Westminster countries such as New Zealand and elsewhere. It is also supported by parliamentary officers such as the Auditor-General and others. All of these enable Parliament to reach into the executive and bureaucracy and scrutinise their actions and inactions.

The key to effective scrutiny is information. Without informed understanding scrutiny will be meaningless. As Max Weber observed

In facing a parliament, the bureaucracy, out of a sure power instinct, the bureaucracy naturally welcomes a poorly informed and hence a powerless parliament (1947:234)

It is absolutely essential therefore to ensure that Parliament has unfettered access to information. But the use of information is not simply to shed light on plain truth. Parliament scrutiny is not simply about checking the facts or verifying the information presented to it. Rather it must be an interactive and interpretive process through the political and substantive meanings and implications of administrative actions are distilled and contested, so that their legitimacy can be ensured. In such a process, the willingness to engage in dialogue itself is just as valuable as the availability of information. As is often said by the Speaker during Question Time, the 
answer may not have been to the satisfaction of members, but the Minister did address the question. The fact that there is an expectation to answer at all is in itself a check on those who are expected to answer, and an insurance for those who ask searching questions on behalf of the people, for there is inevitably a political price to pay for poor answers in a deliberative forum.

\section{Ministerial Responsibility}

The doctrine of ministerial responsibility is a necessary complement of parliamentary sovereignty. As Smith (2005:104) puts it, "ministerial responsibility is the hinge of the constitution" with Ministers, collectively and individually as "the conduit between the people's representatives and the Crown in whose name government is conducted". The discussion here will focus on individual ministerial responsibility, as it is directly relevant to the issues discussed in this thesis.

Ministerial responsibility has always had its critics. Recently such criticisms have been more intense. For its critics, the doctrine is confusing - it has been variously called "the enveloping haze", "the procreation of eels" and "the hoariest chestnuts of the constitution" (Marshall 1986; Palmer and Palmer 2004; Rhodes 2005). - and ineffective, in need of clarification or even replacement by something altogether more clear and more enforceable. Yet despite numerous obituaries, recent events in the UK appear to show that ministerial responsibility is much more resilient than it has been given credit for (Polidano 2000; Woodhouse 2004). Interestingly, in the UK, the reassertion of ministerial responsibility occurred after the managerial reforms that, according to Savoie (2003:254) "had reduced accountability more than any shortcomings of ministerial responsibility".

So it is quite possible, as Savoie (2003: 257) suggests, that "many commentators who are calling for the doctrine to be jettisoned may not fully understand its application". And consequently this is often confused with, and by, managerial accountability" (Woodhouse 2002:73). The 
difference is fundamental and it points to the basis of ministerial responsibility in parliamentary democracy, namely that "Parliament is entitled to know how the power of the state, which it has assigned, is being used" (d'Ombrain quoted in Savoie 2003:257). In other words, the essence of the doctrine is the political responsibility for power. Thus conceived, ministerial responsibility serves as a bridge between bureaucracy and representative government: it facilitates parliamentary scrutiny by securing and providing information upwards and, in turn, helps to ensure political legitimacy of bureaucratic actions through delegation. Moreover the logic of having a politician taking responsibility for bureaucratic acts is that the political/power dimension of bureaucratic actions themselves cannot be easily avoided. This holds the key to understanding the doctrine of ministerial responsibility.

A focus on power help explain why the Minister is the focus of the responsibility, rather than bureaucrats or managers who actually deliver the goods, and why it is the Minister who must be responsible for the conduct of their officials even if he/she does not have direct control over. The latter is known as "vicarious" responsibility (Mulgan 2002; Scott 1962). This concept often creates confusion, however, partly because the contrast between "vicarious" and personal/primary responsibility easily lends itself unfortunately to all sorts of dichotomies that were probably not intended originally. Such a distinction is based on a distinctive causal notion of responsibility. The problem with such a conception is that it inevitably falters in political reality when causality is often ambiguous, and when individual shares of collective actions are difficult to determine. Adherence to the causal notion of ministerial responsibility therefore tends to paralyse the doctrine, and renders it ineffective. Moreover, it often seems to leave little choice but to either invent an artificial boundary between Ministers and Officials can be made responsible for, directly and causally, that inevitably leave a large gap over the grey areas, or to blame the fictitious "system". And yet, as Smith (2005:109) observes, "if public servants were given more direct authority and...more direct accountability, then this would undercut the authority and responsibility of Ministers". This 
in turn is likely to increase the risk of blame shifting for collective failures. The problem is well understood by $\mathrm{J} S$ Mill, in fact, as he cautions that

responsibility is null when nobody knows who is responsible. Nor even when real, can it be divided without being weakened. To maintain it at its highest there must be one person who receives the whole praise of what is well done, the whole blame of what is ill (1962: 332).

Yet a more "traditional" reading of the doctrine easily dissolves such difficulties. For the doctrine allows Ministers to take the whole credit and requires them to take the full blame, simple because of who they are. This is the role notion of responsibility, which, explains Woodhouse (2002:77) following H L Hart, "arises from the minister's 'distinctive place or office'”. It implies that, Woodhouse adds, "Ministers are constitutionally responsible for their department not because of their detailed involvement in departmental affairs, but because of the positions of public trust they held" (ibid.). It is therefore the role of the Ministers to ensure that the power of the state, which keeps the "system" running, is used consistently with public expectation, no matter who exercises it on their behalf. In this way, the doctrine of ministerial responsibility ensures that personal responsibility for collective, bureaucratic, actions will not be lost, because responsibility can always be traced up the hierarchical line to the Ministers and the Prime Minister.

There are a number of well-established ways that Ministers can give effects to the doctrine. The minimum of responsibility is answerability for personal and departmental actions. In addition there is a requirement for rectification. And finally Ministers may be asked to resign (Joseph 2001; Mulgan 2002; Smith 2005; Woodhouse 1994). Critics of ministerial responsibility often point to its inadequacies in terms of these components, particularly the lack of resignation. 
But there is a risk that focusing solely on these means might obscure the point that ministerial responsibility is political, and not legal. It "begins and ends in exercises of political judgment" (Uhr 2005a: 6). Political judgment goes two ways; it includes not only that of the Ministers and other politicians involved, but also, and perhaps more importantly, that of Parliament and the public on the roles of Ministers. The implication is that ministerial responsibility cannot guarantee either the distribution of blame or enforcement of sanction. As everything political, ministerial responsibility provides much less certainty than legal requirements. Understandably, this may be a source of frustration for some who believe that Ministers are clearly culpable and deserve punishment. And opposition will always ask for heads to roll. But in politics causal relations are rarely as clear-cut and there will inevitably be disagreements over the existence and degree of responsibility for collective actions, which are themselves political. Therefore, one danger with "clarifying" ministerial responsibility is that it may restrict the scope of political responsibility and bind it to a causal notion of responsibility. Moreover, raising the bar higher might actually make it difficult for the public to hold Ministers responsible for lesser offences. This is why that attempts to codify ministerial responsibility in Australia and the UK "may have done more to sabotage the convention than to preserve it", as one commentator puts it in the Australian case (Raffin 2008; Tomkins 1996; 1998). To increase legal responsibility may well reduce political responsibility.

A political conception of the ministerial responsibility also means a reappraisal of the relative importance of the different elements of responsibility. In this light, the "minimum" requirement of answerability is arguably the most important component of responsibility. Responsibility as answerability to Parliament is not to be confused with (managerial) accountability as distinct from responsibility. Given a role notion of responsibility, such a distinction between accountability and responsibility is less appropriate (Woodhouse 2002). As Woodhouse explains, the role notion of responsibility entails a shift in focus to: 
first, whether the minister has been negligent or incompetent in the overall supervision of his department, a conclusion that may be reached when there has been a succession of errors or when, after a major incident, there are found to be systematic failures within the department. Secondly, whether the minister responds adequately, in terms of explanation and amendatory action, when things go wrong. The emphasis is therefore on giving information and satisfying Parliament and the public that mistakes have been rectified and mechanisms established to prevent a reoccurrence on similar errors (2002:78-79).

So responsibility as answerability may be "a matter of political and organisational house-keeping" (Gregory 2003a: 558). But it also provides for political accountability, and therefore political responsibility, for in deliberative politics, speech is action.

Neither should one undervalue the significance of amendatory actions. For one thing, it often shows the strength of political accountability in compelling the Ministers to act. For another, it forces politicians to assume more responsibilities and even direct control of the bureaucracy to make things happen, taking into account of the opinions expressed by Parliament and the public through the debates on responsibility. This is significant in itself, particularly with a role notion of responsibility where "rectification" is often not simply a matter of righting wrongs, but responsiveness to the changing political judgments of Parliament and the public.

With regard to resignation, it is generally acknowledged by constitutional commentators that resignation is not necessarily required as part of the doctrine (Mulgan 2002; Palmer and Palmer 2004; Woodhouse 2002), although sometimes not without a note of acquiescence. A focus on political responsibility illustrates why the obsession with ministerial resignation, or the apparent lack of it, misses the constitutional point. The problem is that resignation is often demanded as if an alternative to 
requirements of answerability and rectification. The need for answerability, as argued above, acknowledges that, in most cases, there will be different opinions about the extent of political responsibility. It follows therefore there will often be different views as to whether mistakes are indeed so grave that Ministers have to resign. And it would be naïve to pretend that these disagreements do not exist. The doctrine, of course, never says that Ministers should not resign for departmental failures. It simply requires such decisions to be made by Parliament and ultimately the public themselves at the ballot box. If Ministers have so clearly failed to satisfy the public, then they should resign, and most likely they will be forced to, sooner or later. And if their defence or excuses have been accepted by Parliament, then they are perfectly entitled to hold on to their offices, for the time being. It must be up to the people themselves, and not some presumed moral or ethical standards, to choose their representatives, or to dismiss them. As the UK cases show, it does not even matter whether a conclusive causal case can be established: Ministers have resigned for much less (Woodhouse 2004). Thus a requirement of resignation will not add any value to the doctrine of ministerial responsibility.

Finally, one can proceed to examine the question of what exactly Ministers are responsible for. The answer, in short, is that Ministers are responsible for the exercises of their political power, as their roles required, and nothing more. This role may include their personal conducts, or their actions and inactions, or departmental policies and administration. It is impossible and indeed undesirable to specify a laundry list of what they should be responsible for (and what they are not). It does not, and should not, matter whether the consequences are actually or primarily caused by the Ministers. Ministers can be held responsible, or even forced to resign, for something which they have only a tenuous involvement, as in the case of resignation of Lord Carrington when the Falkland Islands were invaded (Woodhouse 2002:74). All that is required is that the public must be satisfied that the Ministers have done at least what the public expect them to do with the power granted to them. Of course, it may still be true that Ministers cannot be sensibly held responsible for everything that goes on 
in his or her department. The point of the vagueness and ambiguity of ministerial responsibility, however, is that ultimately people themselves must be convinced of what Ministers, or bureaucrats, are or are not responsible for, rather than having to accept some predetermined separation which increases the chance of blame shifting and often conveniently reduces responsibilities of both. As John Uhr (2005a) argues, ministerial responsibility can take on "as rich and sparse a meaning as parliamentary antagonists want them to mean". This is as it should be.

\section{Political Neutrality}

Another building block of the Westminster system is a non-partisan and expert civil service (Rhodes and Weller 2005). Its constitutional status certainly illustrates the intimate relationship between bureaucracy and liberal democracy. However, it does not necessarily follow from this constitutional importance that the role of public servants in a Westminster system is, as some commentators argue, to serve as the "platonic guardian of public interests", independent from the political sphere of government (Sossin 2005; Rhodes 2005). In fact, such a notion fits perhaps more easily into the German model of civil service than the Westminster system. The difference is partly historical. The Prussian bureaucracy that Weber described had evolved as an administrative institution above underdeveloped politics and eventually became properly the guardian of the constitution. In Britain, by contrast, the emergence of modern bureaucracy was predated by the constitutional settlement, as a part of which the control of bureaucracy was transferred from the Crown to the Parliament as a result of the struggle for power (Woodhouse 1997). The point here is that taking a longer historical view suggests that the purpose of the convention is not to insulate bureaucracy from politics, quite the contrary, it is all about political control, by Parliament, over the bureaucracy. Moreover, it posits the convention of political neutrality within the relationship between Parliament and the public service, rather than solely between the government and the latter. 
This is an important step towards a proper understanding of the convention of political neutrality and it helps frame debates around political neutrality. In this regard the "government centred" view has certain shortcomings. Take, for example, the New Zealand State Services Commission's definition of the doctrine that:

public servants should serve the government of the day professionally and impartially, and do nothing that will limit their ability to serve, with equal professionalism, future governments of a different political persuasion (SSC 2008),.

There is nothing intrinsically wrong with this statement, which is fairly conventional. Yet, on its own, it provides no answer to the old criticism that,

Neutrality in public office tends in the end to moral corruption. If all governments are to be served with equal impartiality and loyalty there are no grounds at all for criticizing the German official who served Hitler to the best of his ability. In any profession other than government such people would be regarded as dangerous cynics or weaklings (Chapman 1963:275).

This does not mean one must abandon the convention of neutrality however. It simply points to the risk of looking at the convention in isolation of the historical and political contexts. For it overlooks the fact that the convention of political neutrality in the Westminster tradition is constrained by the doctrine of parliamentary sovereignty. This in turns means that neutrality and loyalty is grounded in the democratic process. Neutrality and loyalty in this context do not mean public servants, as political actors, can ever be apolitical, let alone amoral. Quite the contrary, they have a political and moral duty to respect institutions of democracy, including whatever government that has been democratically elected by the people, and because of this reason they must be non-partisan. Thus, the public service is not, and cannot be, neutral between the government and the opposition 
(Mulgan 2006:4, Weller 2003:83). Rather, public servants are required to be "political chameleons and there are strict rules to prevent them becoming political animals: the logic of the convention is that a political chameleon can never be a political animal" (Shepherd 1986:69). And what distinguishes these two kinds of animals is that the latter can exercise their political power independently while the former cannot. The point of the convention therefore is not to protect the instrumentality or objectivity of the public service: it is to ensure that public officials are "politicised" in a way that is consistent with the political decisions legitimately made through the democratic process, rather than the private morality or ethics of their own, or the partisan values of those who had not been legitimised by the democratic process. The convention of neutrality takes away the independent political power of bureaucrats and gives it to politicians, who are in turn politically responsible to, and removable by, Parliament. In this sense, the justification of political neutrality lies at the very heart of liberal democracy.

In this light, Chapman's objection to the principle of neutrality actually confirms the political necessity of neutrality and shows the danger of elevating certain values above democratic politics. Hitler's bureaucrats were clearly not "politically neutral" by Westminster standards, for they had no commitment to liberal democracy and this alone is enough for condemnation. "Constitutional guardians" could easily turn into the enemy of democracy. Here lies the conundrum: Quis custodiet ipsos custodes?

While there is no place in the Westminster system for the "platonic guardians of public interest", the convention of neutrality does provide a powerful check on both political and bureaucratic powers. This is achieved firstly through the "bargain" implicit in the requirement of neutrality itself (this forms a part of the traditional Schafferian bargain common in Westminster countries, see Hood and Lodge 2006 and chapter 5). While bureaucrats, as argued above, must give up their political independence, politicians, in return, are required to take political responsibility. In this sense neutrality is also a necessary complement of ministerial 
responsibility. In order for such a relationship to work, trust between bureaucrats and politicians is essential, not the least because what is at stake here is political power and therefore political legitimacy. Secondly, the corollary of responsibility in the Westminster system is loyalty. It does require officials to respect the authority of politicians when disagreements arise and not abuse the terms of trust in such circumstances, through for instance, strategic leaking. But loyalty does not mean blind obedience and passive deference. As Weller (2003:87) argues, "assisting the minister in his [sic] objectives by the best possible means occasionally requires challenging the objectives and the approach". Arguably ministers are best served by "positive scepticism" of officials, guided by a 'no surprise' principle ${ }^{9}$, than a false sense of security. It is where bureaucratic expertise can complement, rather than undermine politics.

So here is the political constitution of Westminster. It makes no grand promises. What it provides often seems simply a long and uphill struggle. But nonetheless the political constitution is worthwhile because amongst other things, it provides a framework for exercising democratic control over bureaucracy. Politics still offers the best hope to make liberal democracy work. That is the theory at least. The next part of the essay will examine the practice of the public services reform in New Zealand against this theoretical lens.

\footnotetext{
${ }^{9}$ Officials in the Westminster world are familiar with the requirements of 'no surprise'. As the New Zealand Cabinet Manual state: "In their relationship with Ministers, officials should be guided by a 'no surprises' principle. They should inform Ministers promptly of matters of significance within their portfolio responsibilities, particularly where these matters may be controversial or may become the subject of public debate" (Cabinet Office 2008: 3.16a).
} 


\section{The Bad Old Days?}

\subsection{Politics of the Welfare State}

The history of New Zealand's modern public service can be traced back to 1912. It is not simply a coincidence also marked the end of the Liberal experiments, which herald the latter Welfare State. The development of the bureaucracy was, as argued above, an integral part of politics and in this case the politics of the Welfare State.

It has been argued that New Zealanders have generally an ingrained weariness of grand political theories and are instead inclined towards pragmatic responses to local issues. This has been described as "Socialism without Doctrine" (Metin 1977). And yet to burrow a little deeper beneath the mish-mash of ideas that fed into the legacy of the Liberal and Labour experiments, one could easily discover translations, varied as they are, of liberal ideas of liberty and equality. Liberal's heritage, as Sinclair (2000:173-4) points out, had come directly from Mill and George and from the harsh life lessons that taught the settlers such as Seddon genuine liberty can only be secured through equality.

Labour picked up where Liberal had left off. Not only did it give concrete shape to the pursuit of these radical ideas though the progressive expansion of the Welfare State, more importantly, it also affirmed them as social and citizenship rights, thereby entrenched them deeply in New Zealand's political culture (McClure 2004). As Sinclair puts it, Labour's social welfare state was "shaped by the ideal of equality: it makes men [sic] more free" (2000:273). This is encapsulated in the aim of the Social Security Act, to quote Michael Joseph Savage, "to make an end to poverty", to safeguard the orphans and invalids "against want and neglect", and to free dependent individuals from being "an economic burden to relatives or friends" (Gustafson 1986 quoted in Boston 1999). But the Welfare State was also a contradictory construct as many historians carefully pointed out. The ideals were never fully realised. And 
some of its values were limited by the bias and prejudice of its time and at times downright discriminatory and oppressive towards women, Maori, gays and other minorities. And there are plenty of setbacks and revisions. The liberal ideals provided powerful political energy and inspiration, but the ideas of Welfare State evolved only slowly.

Discourse of the social, and its relationship with the individual, is central to the Welfare State. The concept of social security, as McClures (2004) points out, embodies a reciprocal relationship: on one hand, it placed on the state the collective responsibility for satisfying private needs of the individual, on the other it confirms the latter's citizenship and the sense of belonging. It was, in Zygmunt Bauman's terms, the two-way translation between the private and public. The most far reaching innovations of the Welfare State - social security, free public health and education systems, old age pensions - are not just about public solutions for private problems. Rather their significance lay in the attempts to deconstruct what had been taken for granted as "private business" into public and political issues, and conversely "public interest" into private rights, through the democratic process instead of economic transaction. Thus in this light the Welfare State entailed negotiating between the private and public spheres and asserting publicly the primacy of individual autonomy and equality. This might make it easier to discern the humanitarian and liberal vision encapsulated in Savage's creed that "social justice must be the guiding principle and economic organisation must be subjected to social need" (quoted in Sinclair 2000). Again such an approach was not always followed. History of New Zealand's social policy in areas such as mental health and child abuse shows that there could be a dangerous swing: on one hand, the translation into the public could become alienating, paternalistic and intrusive for some, whilst others were left to their own in the face of collective denial (Dalley and Tennant 2004).

There is a deeply rooted popular notion that the politics of the Welfare State was dominated by consensus, or conformity, founded as it was on a "classless society". Whether one finds in this nostalgia or dullness 
depends often on one's ideological stand. However such a claim can scarcely be sustained. For most of its life the Welfare State had faced formidable challenges, first from hostility against state intervention at its inception, and then against the rise of individualism during the 60s and 70 s. Even the 1950s, although relatively calm, was never free of conflicts the 1951 Waterfront Strike ${ }^{10}$ is one example of the conflicts underneath driven perhaps more by a desire for normalcy than anything else with the help of favourable economic environment (Dalley 2005; Gustafuson 1996; Rudd 2001). But the politics of consensus has another meaning, which is sometimes unfortunately confused with imposed consensus and then becomes justification for the dismantling of the welfare state. According to Mulgan, the politics of consensus or consensus politics may refer to:

not so much to the absence of political conflict in society as to a method by which such conflict is handled by political elites. Consensus politics implies that political opponents, particularly politicians from rival political parties, seek to reach agreement by accommodating each others' differences. It is a politics of compromise and conciliation in which opponents share ultimate responsibility for decisions reached through negotiation (1997b:325).

This is a more appropriate description of the politics of the Welfare State. The Industrial Conciliation and Arbitration system is one example of such an approach to politics and it is also an excellent illustration of how imagined or imposed consensus can, paradoxically, become the worst enemy of consensus politics. Yet there is no doubt that the political institutions of the Welfare did not fit comfortably with consensus politics. The first-past-the-post electoral system coupled with unicameralism, which Mulgan (1992a) labelled "elective dictatorship", constrained perhaps only by a strong political culture, is inimical to consensus building.

\footnotetext{
${ }^{10}$ The 1951 Waterfront Strike, sometimes referred to as the Waterfront Disputes or Lockout, is the largest industrial conflicts in New Zealand history. It was the result of the unwillingness of the employer to apply the decision of the Arbitration Court to increase wages by 15 percent (waterside workers were not covered by the Arbitration system). It lasted 151 days and at its peak mobilised 22000 workers, which accounted for more than 10 percent of population then.
} 
There are two points underlying the account above. First is that the Welfare State itself can be regarded as an application, however imperfect it is in retrospect, of liberal ideas: the centrality of liberty and equality, the importance of society, and the primacy of politics. Second, the actually realised Welfare State, is also full of paradoxes and contradictions. This sets one important theme for the next section.

\subsection{A Weberian Bureaucracy?}

The new responsibility for the state prompted a search for new ways to organise and deliver. Private provision for public welfare, or public-private partnership as it is now fashionably called, continued to play a critical role in the new welfare state, for instance, in the provision of state housing, under both Liberal and Labour. But an increasing demand clearly increased the pressure to "modernise" the public service.

Perhaps out of habit New Zealanders looked to Britain for inspiration, more specifically, to the Northcote-Trevelyan reform. The result was a unified non-partisan merit-based career public service. With hindsight, it seems easy to blame the reformers then for ignoring the obvious dangers of bureaucratisation in this "modernising" agenda" 11 . But to what extent does the Welfare State actually resemble the ideal type of Weberian bureaucracy?

Of course, the reformers of 1912 did not set out intentionally to create a bureaucracy in Weber's image. For them, the "modernisation" agenda of the public service of the conservative Reform government was perhaps more accurately described as a reaction to, rather than a consequence of, the proto-type Welfare State built by its Liberal predecessor. It is with this intention that the 1912 Hunt Commission sought to emulate the best

\footnotetext{
${ }^{11}$ Indeed the Liberal's reluctance to adopt the Northcote-Trevelyan model was partly a result of their fear of bureaucratisation and its potential to undermine democracy (Henderson 1990).
} 
contemporary "business method" of the private sector - unsurprisingly perhaps, since the commissioners were all prominent businessmen, for whom the use of business methods to constrain government had long been an important political cause (Henderson 1990). History was to repeat itself in 1984 when making the Public Service more "business-like" once again became popular as a panacea for bureaucratic ills.

\section{$\underline{\text { Scientific management in Government }}$}

But if bureaucratisation of the Welfare State is an "unintended" consequence of borrowing from the private sector, it is nevertheless an inevitable one. A narrative of bureaucratisation can start with the rise of "scientific management" or Fordism. In New Zealand the idea had already taken its root in the private sector for some time, particularly in large meat works, where "bureaucratisation" - rationalisation, specialisation and consolidation - was welcomed with open arms, as it did increase markedly efficiency and profitability (Olssen 1992). Unsurprisingly the reformers sought to transplant its success to the public service, and not the least because the "apolitical" appearance of "scientific management" sounded far more positive and fashionable than overt political advocacy of business method.

The influences of scientific management cannot be underestimated, partly because it laid down the fundamentals of a bureaucratic model. Amongst its chief legacies was the primacy of "efficiency" in the dual sense of procedural compliance and economic productivity. Ostensibly fighting against political patronage, the reformers themselves clearly saw "efficiency" - cutting "waste" in government - as the primary objective of the new public service (Henderson 1990; Scott 2001). Moreover it was understood that, in more specific and less political terms, the concept translated to maximising the ratio of outputs to inputs (economic efficiency), and as a corollary, more economic use of inputs (economy) (see Johns 1979). Correct application of scientific management rule - the notion of efficiency as procedural compliance - was the necessary means 
to achieve it. Hence the 1912 Act and later the 1962 Act were both centred on the objective of "efficiency and economy". The history of the public service, therefore, is synonymous with "the quest for efficiency". So the problem with bureaucracy is not that it is intentionally "inefficient". Rather, as Gregory argues, it was because an overriding purpose with "procedural efficiency" was pursued at the expense of the "higher forms" of efficiency, particularly efficiency in its broader sense of effectiveness (Gregory 1982). That is to say that the bureaucracy is "efficient" in its own terms: efficient production of what might be simply "red tape" to others is efficient nonetheless.

The quest for (bureaucratic) efficiency was closely associated with the metaphoric image of mechanistic production, or the production organisation in Wilson (1989)'s terminology. The central message of "scientific management" after all, and one which was explicitly adopted by the Hunt Commission, was that efficiency can only be achieved if organisations were to function like a "well-oiled machine" run by "scientific administrators" (Henderson 1990). Although this mechanistic vision as an ideal had gone out of fashion as early as the 60s - the McCarthy Commission had argued for a more "organic" alternative albeit in rather vague terms - it nevertheless has a strong and lasting impact in practices.

Accompanying this mechanistic process was an insatiable urge towards greater "rationalisation" in the Weberian sense of active search for greater calculability and therefore potential efficiency. Contrary to the popular conception, the bureaucracy, in New Zealand at least, was perhaps only too ready to embrace the latest managerial techniques that facilitate better measurement and planning of efficiency. Adoption of contemporary accounting practices was part of the modernising agenda of the 1920s (McKinnon 2003). This was followed by "operational research", developed during the war as a scientific method of providing a quantitative basis for decision making in the 1940s and 50s (Henderson 1990). The 1960s and 70s saw a litany of acronyms - CBA, PPBS, ZBO, MBO, TQM - made their appearance in New Zealand's Public Sector (Gregory 2004c). 
Despite their diverging messages, these fashions or fads were all unified by their promises of better methods, and usually quantitative methods, to render complex social and economic systems more calculable and predictable.

But if these processes disempowered bureaucrats as human beings, they also empower them as technical experts or specialists with exclusive access to "objective" knowledge on the running of the machine (and consequently disempower other political actors). The merit principle already prepared the ground for the officials' claim to power by virtue of their expertise. And the dominance of legal and commercial professions in New Zealand's traditional public service - lawyers, accountants, economists, and to lesser extents management consultants - indicated a preference for a particular kind of expertise i.e. instrumental knowledge about the application of rules and calculation of means. This power of expertise is greatly enhanced by the "cloak of secrecy" - the Official Secrets Act - that surrounded its exercise.

Technocratic expertise is one source of power in a Weberian bureaucracy; exercise of discretion is another. This point is often lost in the misconception that focuses entirely on the rigidity of bureaucratic administration (hence the needs to "free the managers") - strangely perhaps - in contrast with the more nuanced and perhaps mature perspective of earlier commentators who had to do without the benefit of hindsight. R S Milne for instance is notable not only for maintaining strongly the "inevitability" of administrative discretion but also for explicitly linking the existence of discretion to the exercise of power rather than simply the growth of the welfare state (Milne 1957).

The discussion above is the conventional stock of a Weberian perspective. And it demonstrates that certain parts of the New Zealand Public Service before the 1984 reform are characteristics of a Weberian ideal type. But this account needs to be supplemented by the so-called welfare professionalism (Clarke and Newman 1997; Clarke 2003). 
This term implies, via "professionalism", important similarities in the way power is organised and exercised. The bureaucratisation thesis could be reframed in terms of professionalisation, for instance, the rise of accountancy as a profession under the Welfare State where professionalisation became very much a short cut to political power ${ }^{12}$. There are, however, important differences that put the focus instead on "welfare".

Firstly, the term welfare, unlike economic growth, had come to embrace a diverse and often contradictory collection of meanings and values under the Welfare State. It could not be easily reduced to a singular ratio between outputs and inputs, or indeed to any other simple measures. In some cases, such as health, the conflicts were clear between the need for efficiency and a commitment to professional ethics, which in rhetoric at least, explicitly overriding. So it is more appropriate to describe welfare professionalism as a pursuit of "effectiveness", rather than efficiency. Apart from these wider purposes which each State activities is intended to achieve, the McCarthy Committee argues, efficiency has little meaning (McCarthy Commission 1962). Moreover, the Commission adds, effectiveness depends on responsiveness to changing social needs and acceptability to the public, which in turn merges with political desirability. This does not resolve the issue of gauging effectiveness as much as problematise it. It casts the focus back onto the politics of value conflicts and the political process. These disparate and conflicting values are held together paradoxically by the vague ideals of the Welfare State that

\footnotetext{
${ }^{12}$ The first professional association of accountants was established in 1894. Professional examination soon followed, conducted by universities. In 1904 the first professional journal was published However, it was not until 1960s that accountancy was actually taught in universities as a degree subject, which marked the high point of an increasing demand for formal training and education. The 1908 legislation recognised the authority of the association in regulating its own members and its monopoly over the title of chartered accountants, thus helped achieve the necessary 'occupational disclosure'. All these were traits of professionalisation. Commerce was ostensibly the drive. Yet this could not be possible without the clearly visible hand of the state. Interestingly, Peter Barr, a member of the Hunt Commission, and an accountant himself, was instrumental in the process of professionalization. Power flows the other way too. Treasury, through the rise of accountants, and later economics, transformed itself from relative unimportance to possibly the most powerful government department (McKinnon 2003).
} 
produced them. For whatever the differences are, the power of professionals as officials, or bureaucrats, ultimately owes to the existence of the Welfare State and its legitimising value.

This is particularly true for those so-called "helping" professions teachers, nurses, social workers - who had a strong affiliation historically with the New Zealand Welfare State. It is telling that the founding principles of New Zealand's public education system appealed not only to professional values of teachers, or to the power of knowledge, but more explicitly to egalitarianism ${ }^{13}$. Such a spirit is deeply ingrained, so much so that the New Zealand bureaucracy became itself an epitome of the egalitarian spirit (Smith 1974:15, 65; Mascarenhas 1984:18). Of course, one must always be cautious not to "romanticise" the values of professionalism. It was not immune to the problem of goal displacement. It is an ever-present temptation to reduce the politics of the welfare professionalism to something simpler and more coherent, such as the Hippocratic Oath. And this can be just as troubling as the single-minded pursuit of efficiency. But the existence of the Welfare State, at once diversifying and unifying, set down an inherent limit of how far the goals can be reduced. It is not surprising then that the managerial reforms were perceived to be a challenge to the Welfare State, bureaucracy and professionalism at once (see Easton 1999).

Secondly, the relation between professionals and citizens could be at times just as "dehumanising" as the relations between bureaucrats and citizens. Lake Alice Hospital provided New Zealand's own and probably extreme experience with the danger of the dehumanising power of professionals. The Welfare State's anxiety with social problems could easily obscure its humanitarian roots, as the provision of welfare became increasingly divided into separate realms of "problem solving" and

\footnotetext{
${ }^{13}$ In a statement prepared by Clarence Beeby, then Assistant director of Education, Peter Fraser, the Labour Prime Minister declared in 1939: "The Government's objective, broadly expressed, is that all persons, whatever their ability, rich or poor, whether they live in town or country, have a right as citizens to a free education of the kind for which they are best fitted and to the fullest extent of their powers. So far is this from being a mere pious platitude that the full acceptance of the principle will involve the reorientation of the education system."
} 
entrusted to professionals with specialist knowledge. The clients themselves often became the problem in the eyes of the professionals. In the instance of social work, it was found in a 1982 study that skills such as problem-solving, client and resource status assessment, case and workload management which were manipulative - or one might say dehumanising - of clients were given much higher priority than solutions that involved social change (Simpson 1984:186-187). The expectation was for clients to fit into "the society", rather than for the society to adjust to human beings. But this does not change the fact that in reality the work of professionals, particularly the helping professionals are immensely personal. Labrum (2004) for instance emphasises the importance of discretionary welfare under the Welfare State, and the particular personalised relationship it engenders. It reinforced, Labrum argues, a "very localised, intimate relation of the 'state'". Professionals, in a sense, were the human faces of the machine-like state.

Moreover, the State itself provides an important counter-balance to the dehumanising tendency of professionalism, for it affirms the rights of citizens. Ironically perhaps the "bureaucratic" rules and standards were crucial to ensure some basic respect for the patients' dignity were maintained, even though the reality may often fall short of bureaucratic inspirations, particularly given fiscal constraints (Brunton 2004). The New Zealand Public Service was, as Mitchell (1969:181) puts it, "a friendly neighbourhood bureaucracy" which served as "the collective embodiment of the people". The culture of equality is by definition anathema to the hierarchical structure of welfare professionalism. Smith (1974:103-110) had found that the culture in departments were much less impersonal and more relaxed, with a high degree of trust between superiors and subordinates in contrast to the Weberian bureaucratic model. A singular emphasis on dehumanisation or the reification in narrating welfare professionalism is therefore clearly inadequate.

Thirdly, like bureaucrats, professionals draw their power from the possession of specialist knowledge. And they share with the bureaucrats 
the "aversion to politics" resulting from "a built-in animosity between the professional and bureaucrats". (Mosher 1982:118). Welfare professionalism in New Zealand was not exception to this discourse of professional power. The established professions, doctors and lawyers, easily laid claim to new territories in the Welfare Bureaucracy as the expertise was revered and taken for granted by legislators as a principle for designing the bureaucracy. Occasional complaints - one commentator lamented that the Department of Health was "doctor ridden" - simply confirms the extent of such power and control. New professions - the emerging and helping professions - had a harder time to lay their own claims to power and ended with varying degree of success. These technocratic ideas often become inseparable from the politics of the Welfare State.

However, it would be simplistic and wrong to reduce one into another, for example, in the joining of Keynesianism with the Welfare State. The Labour Party did use a few vague Keynesian slogans before its election because Keynes appeared "almost Fabian" - but there was no evidence of any plan to put it into practice (Easton 1981; Sinclair 2000:265). It was the young economists at the Treasury who were enthusiastic to mould their advice according to the new orthodoxy to improve economic management. Labour by contrast wanted only to make economic organisations work for their wider social goals, in which their humanitarian vision was really grounded. And they, in a sense, simply expanded on what Liberal did and what the Vogel ministry did earlier. It is the "pragmatic" tradition of New Zealand politics, rather than the orthodox application of economic management, that stood out here. This difference, in a sense, reflects the divide between technocratic and political mentality. And it appeared that senior officials have understood this well. Whether the advice was informed by neoclassical or Keynesian thinking, McKinnon (2003:162-163) comments, "it was always usable". It was not until the 1950s Keynesianism has been recognised as the orthodoxy, when the Labour Party has already lost its "socialist" reform zeal perhaps not purely by coincidence (McKinnon 2003). The point here is that the Welfare State is not a 
monolithic monument of professional or bureaucratic power. Rather it was the site of conflict and contradiction.

Put these two models together, a different picture emerges than the standard Weberian image. Indeed, there was a strong tendency of bureaucratisation, reinforced by professionalisation, but the degree of bureaucratisation was limited by the values, norms and politics of the Welfare State.

\section{Command and Control}

The term "machinery of government" is often used to describe the interorganisation relationships of the traditional service. Such a metaphor inevitably provokes a pejorative mechanistic and bureaucratic image, which was probably not entirely inaccurate. Like a Weberian bureaucracy, the public service was run, or was supposed to run anyway, under a hierarchical structure tightly controlled from the top down through a long chain of command, which connects the departmental officials with control departments such as Treasury and SSC and ultimately with politicians within a single unified pyramid-like structure. In this way the machine bureaucracies could be integrated into a larger piece of machinery and made to operate efficiently to certain inner logic as those on the top see it.

But again this simplicity can be deceiving. The actual institutional design, although undoubtedly hierarchical, was anything but simple and rational. By 1958 It was composed of "forty one departments of the state and almost one thousand local authorities, government sponsored companies and public or semi-public corporations" in a country with a few million people: the picture is no less complex today (Polaschek 1958:3; Gill 2008). This points to the so-called "sectoral" approach under which these public organisations were created in the first place (Boston et al 1991, 1996; Savoie 2003). The sectoral approach groups organisations based on their political raison d'etre. It was simple: define an area of responsibility, label it say social security, and allocate all responsibilities for that purpose. The 
hierarchical order, by contrast, is a "functional" approach in a sense that it lends itself easily to schemes of rationalisation through regrouping and amalgamation aimed to increase bureaucratic efficiency ${ }^{14}$ (Polashek 1958; McCarthy Commission 1962). The institutional design, therefore, inevitably embodies the contradictions between these two approaches.

On its own, the hierarchical order tended to project an instrumental and bureaucratic view of coordination, directed towards a presumed higher value or perhaps an objective order of values. And the instrumental emphasis inevitably gravitates towards efficiency and economy. By contrast, in practice, "most machinery of government changes were the result of new policy initiatives or changing social needs or political manoeuvring; they were not the product of efficiency drives or the application of grand bureaucratic design" (Boston et al 1996:77). These policy initiatives and social needs in turn defined the sectoral bases for individual organisations and inevitably brought with them distinctive political values and objectives. The combination of these two approaches, if only by accident rather than design, was essential. As Boston et al (1996:71) argues, "institutional design poses important normative, political and symbolic issues; it is thus centrally about values, and their relative importance". And the sectoral approach provided a richer normative, political and symbolic content while the hierarchical order supplied an overriding common purpose. These two parts formed a basis for coordination of substantive conflicts among sectoral objectives.

What was needed was a formal coordinating mechanism. And this was provided by the hierarchical chain of command through which the agencies were connected to other units within the organisation and upwards, via the control agencies e.g. Treasury and SSC, to the Cabinet and its committees (McCarthy Commission 1962). While this was highly

\footnotetext{
${ }^{14}$ Some might argue that the functional approach is also purpose-driven since they must contribute to the same purpose of the Government as a whole (see Polashek 1958). This however ignores the fact that not all goals can be reconciled easily and meaningfully with a higher end, particularly if they are filtered through the democratic politics. This actually confirms the instrumental nature, in the Weberian sense, of a functional approach,
} 
effective, it might also be cumbersome and costly, since "coordination" could only be achieved through vertically imposed impersonal authority. This was what Gregory (2003c:52) called a "strong mechanistic system which produces net benefits for members and the wider community". But coordination also takes place through other more "organic" and relational means, for example, through the informal "old boys networks" among officials, which was reputedly a feature of the old New Zealand system (Gregory 2003c). While it is difficult to assess the exact extent of these and other informal networks, especially given the cloak of bureaucratic secrecy over them, but it seems reasonable to assume that these had considerable influence, amongst others, over policymaking (Goldfinch 2002). By contrast, the institutionalised consultative forums, which not only include bureaucratic players but also external interest groups, provided a more open and transparent means of coordination. Many of these however did not survive long after 1984.

Finally, one comes to the issue of power and control. The existence, and inevitability, of informal networks alongside formal networks where political legitimacy resided in a sense complicated the problem with bureaucratic power. It is more likely to invoke concerns that too much "intimacy", or "particularised trust" in Rothstein and Uslander (2005)'s terms, might depreciate long term "generalised" trust ${ }^{15}$. This poses a risk, especially given the real or perceived oft-elitist undertone of these networks, for ordinary New Zealanders (Goldfinch 2002; Harris 1995). While the bureaucratic hierarchy may appear strongly mechanistic, it serves crucially to push the issue up to those in the real position of power who must exercise their value judgement to adjudicate value conflicts. It shows "coordination" as what it really is i.e. the alignment of powers and thus an act of power itself and highlights the concerns in its exercise for impartiality, probity and legitimacy - the substantive values embodies in bureaucratic

\footnotetext{
${ }^{15}$ Particularised trust refers to situations where people only trust those who already belong to similar social, economic or political groups as them, for instance, those who share the same religious beliefs or are of the same ethnicity/race. Generalised trust by contrast means that people are able to trust others who do not belong to their communities. The latter is clearly essential in a pluralistic society where there are many communities (Rothstein and Uslander 2005).
} 
administration itself. This political perspective seems implicit in the McCarthy Commission's approach, which eschewed the administrative layers of coordination and opted to align the hierarchical chain with the Cabinet system.

\section{Economic Constitution and Welfare Politics}

Finally one must briefly consider the macro issue and this concerns the demise of the Economic Constitution - the tripod of gold standard, balanced budget and free trade - which was marked by the "nationalisation" of the Reserve Bank in 1933 (McKinnon 2003). In one sense, this is the real beginning of the Westminster system in New Zealand, unshackled from the implicit "constitutional" constraints of laissez-faire capitalism.

For some commentators, the rejection of an independent central bank reflected a shift towards the Keynesian theory (Dalziel 1993). But while the control of the central bank is a central plank in Keynesianism, the economic interpretation tends to underemphasize the wider theories about the state and economy than different ways of managing the economy. In fact, as Hawke (1973) argues, the first Labour Government's reform did not in fact change how the Bank operated in practice. The impacts of the reform was not so much economic as political.

In the first place it is not only about difference of means but also about difference of ends. This choice in 1936 on whether or not to nationalise the Reserve Bank was not a simple one between full employment and price stability - that was to come later in the 1950s and 1960s - but between social welfare and economic welfare. Even the term "economic welfare" in the 1933 Act was "a significant step in the State's paternalism towards its citizens", as Bassett (1998, p.176-7) points out. The objective in 1930 has been to maintain the stability in the value of money, which was more true to the economic constitution and the Treasury line. If Bassett's claim was exaggerating, the addition of "social welfare", despite receiving no debate 
in the nationalisation debate thanks to the post-Depression political consensus, was clearly a step further in the tug between paternalism and laissez faire capitalism.

Such fundamental differences can be illustrated from other angles. The Reserve Bank created in 1933 was meant to be, in the words of its governor, "a useful part of financial machine", "to coordinate, consolidate and control the banking system", for the gold standard that was in its place had crumbled (McKinnon 2003:153). This was necessary to cure a "sick" economy and to restore "good sound conservative finance" (op.cit.:132). "The economy" in a sense was the beginning and the end, almost a thing in itself. To the Coalition, the crisis could be phrased in entirely impersonal, even inhuman, terms, as an "economic problem". No excessive tinkering was necessary: the malfunctioning was to be resolved in economic terms, according to its own laws, assisted by economic "doctors" while the harsh lived experiences of people seemed irrelevant. Indeed to conquer the adverse conditions, more sacrifice and hardship were necessary.

Labour had a different outlook. It was equally obsessed with the monetary system and the economy. But to Labour the problem was precisely the impacts of the Depression on people, made worse by the Coalition's attempt to save the economy through a balanced budget. Michael Joseph Savage, for example, had stressed the importance to "control the monetary system" - not for the sake of the economy - but "by doing so to guarantee prices to the producers in the first place and incomes to those whom they employ in the second". It was the living standards of the people, rather than the "health" of "the economy", and therefore the distribution of pains and gains amongst people, that were its primary concerns.

Finally, the change can be discerned in terms of the relationship between politics and expertise. To insulate monetary policy from politics was an important design principle behind the 1933 Act. It was the central Treasury 
faith, as one contemporary recalls, that the elaborate set up were necessary safeguards to assure the Bank of its independence against "dangerous, wild men" that the future might bring (McKinnon 2003). It did not succeed. The future did bring "possible wild men" that the architects of the 1933 Act had feared with the election of a Labour Government. But the political economy changed. The 1936 Act (and the 1939 amendment) made clear the Government's desire to assert political control over the Bank and monetary policy. It was consistent with Labour's philosophy that establishes the primacy of politics over expertise, and democratic legitimacy over elite authority. This approach was clearly at odds with the logic of an independent Reserve Bank. And it was illustrated by a brief exchange between the Reserve Bank Governor and the Labour Prime Minister in 1938 over the issue of exchange control recorded by Hawke (1973). The Governor had argued strongly against exchange control, for it would inevitably require complex and no doubt inefficient, regulations and would do nothing to balance the budget. To this the Prime Minister replied that "our difficulty is that, up to now, no alternative, excepting one which would not be tolerated by the people, has been suggested".

There is a lot of truth in the Governor's assessment, of course. But for Savage, it was what the people desire that ultimately counted. Economic efficiency was not unimportant but it was secondary when the choice had to be made. This was the end of the old economic constitution, for the laissez-faire economic imperatives that underpinned the constitution had lost the control over political imagination and practices to welfare politics.

The New Zealand Public Service prior to the reform did possess certain characteristics of a Weberian bureaucracy, in both its quest for 'scientific' principles of management and its hierarchical structure. But what is equally, if not more important, is the values, norms and politics of the Welfare State that puts a limit on the "rational" authority of bureaucracy. This counter balance, although important, is indirect. And it relies perhaps too much on mutual trust and confidence. The more direct checks and 
balances lie, supposedly, with the political constitution. How then did it perform?

\subsection{More Westminster than Westminster?}

Although recent studies have shown that the pattern of transplant was not as straightforward as it was once thought to be (Wanna 2005), few would dispute that New Zealand's constitutional tradition could be traced to the Westminster Parliament. And, prior to MMP, the unitary, unicameral parliamentary democracy dominated by a strong executive elected by a majoritarian (first-past-the-post) system certainly magnified certain characteristics of a Westminster system to its extreme (McLeay 1995; Levine 1979; Mulgan 1997b). For this reason, New Zealand was once regarded as "more Westminster than Westminster" (Lijphart 1984; 1999). But such assertions are directed not so much towards Westminster as such, as they are at majoritarianism. In order to understand how the Westminster system worked, or failed to work, emphasis on purity or perfection are less useful than paradoxes and contradictions.

\section{Hollow Crown of Sovereignty}

The first paradox is the doctrine of parliamentary sovereignty. If one were to look only at a Diceyan definition of parliamentary sovereignty, as Scott (1962) did, then New Zealand certainly appeared doctrinaire. There were few legal constitutional constraints on parliamentary power. The period in question might easily lend to the impression of a golden age of parliamentary sovereignty, where the doctrine was simply taken for granted. And there were very few explicit challenges to Parliament's power. The Treaty of Waitangi had not yet become a political issue. The courts did not seriously challenge Parliament's ultimate authority. And the use of referenda did very little to abridge Parliament's power. However, as 
Mitchell (1969) points out, there had always been vocal complaints in New Zealand about the weakness of Parliament.

Such complaints must be examined critically, particularly as they often come with talk of the decline of Parliament' by comparing the practices of the day with an earlier "Golden Age". This, he argues, was "a picture so moving and colourful" that is also "completely inaccurate". Indeed, what was often overlooked then - and it is still neglected now - was that some changes in the twentieth century could equally be argued as the "rise" of Parliament and the corresponding decline of private powers. The lack of separation of powers meant that the "expansion" of the state and politics necessarily enlarged the role of Parliament. Keith Jackson raised an important point when he remarked in passing that "it is scarcely more than 40 years ago, for example, when matters of the economy were left largely to the Bank, being hardly fit concerns for governments" (Jackson 1978:16). The fact remains that New Zealand Parliament of the twentieth century had a role - however ineffective and symbolic a role in the face of an all powerful executive and bureaucracy - in many areas of economic management and social welfare where it had not previously.

Nonetheless the critics were right to point out that the highly disciplined party organizations - in a way, party bureaucracies - did pose a problem for Parliament. However, as argued before, the problem was not so much the prominence of parties, nor the strength of executive power, since neither necessarily conflicts with the idea of parliamentary democracy, but majoritarianism, which eroded the legitimacy of Parliament as a representative political institution. New Zealand's own electoral system, which had produced a stable two-party system and a bias against sizeable minority parties, brought out its own illogicality in stark terms when the Labour opposition lost both the 1978 and 1981 elections despite winning more seats. Thus it is not surprising that New Zealand had suffered particularly badly from the "unbridled power" of executive dominance, as Palmer (1987) complains. And this places a severe constraint on Parliament's ability to control the executive and the bureaucracy. 
The traditional perception of Parliament has been summed up by Jackson (1987:37):

the House, as we have suggested, has important deficiencies as a representative chamber; equally it can be misleading to call it a legislature when it actually 'makes' few laws itself'; financial control of the executive is a myth; and the most important political activities take place off the floor in the majority party's caucus where, all too often, what the caucus says goes.

Palmer (1987) described the New Zealand legal system in the 1980s as having the "fastest law in the West", which highlighted the growing quantity and complexity of law, driven by the executive expediency - and in turn enhanced the power and status of bureaucracy as the legal-rational authority - at the expense of parliamentary legislative control. Yet, the multiplication of law, as Palmer himself points out, "in part a response to political demands" driven by the belief that "the government must be seen to be reacting" (op.cit::78). And it showed that Parliament still remained central to this political process. However irritating this may have been for lawyers, politics is itself an antidote against bureaucratization. Indeed, it is more problematic when the exercise of power is not filtered through Parliament at all, for example, in the extensive use of delegated regulations in New Zealand. It was once said that under the Economic Stablisation Act that "you can do anything provided that you can hang your hat on economic stablisation" (Muldoon quoted in Jackson 1978:21). In these cases, parliamentary control of the bureaucracy was virtually nonexistent. Here it is not politics, but rather the lack of it, that was the problem.

The inadequacies of parliamentary control over finance appear equally obvious. With the benefits of hindsight it is easier to see the primitiveness of the control mechanisms. These deficiencies by no means escaped the notice of commentators and were in fact subjects of several attempts at 
reform, including the 1962 McCarthy Commission (Boston et al 1994; Polasheck 1958; McCarthy Commission 1962; McRae 1994). Yet financial control remained focused on the annual cash cost of inputs such as personnel, travel, maintenance and materials without much information on the results and the longer term. In 1978 the Auditor-General concluded that parliamentary financial control was "inadequate", pointing to the problem that "the estimates do not contain sufficient information on objectives and functions of departmental programmes, achievement of goals, or the full costs involved" (Auditor-General 1978).

Parliamentary control was also constrained by its process, which was said to be a copy of "the House of Common's highly complex, ornate and mostly meaningless form" which had little relation to the exigencies of modern financial management (Jackson 1987:148).

To some extent, these problems are ameliorated by the work of the Auditor-General and the Public Expenditure Committee (the Public Accounts Committee before 1962) which maintained a more focused watching brief over the Estimates (Skene 1990). Nonetheless, it is difficult to avoid the conclusion that parliamentary control over finance is "rudimentary at best" (Jackson 1987:148-160). However, one might risk putting too much emphasis on financial management rather than parliamentary control. Indeed, what might be regarded as the weakness of one function may well be the strength of the other. This could be seen in the role of the Public Accounts Committee. On the one hand, its effectiveness in financial control was unquestionably limited, not the least because it "failed" to focus on administrative or financial details, rather than broad policy (Jackson 1987:153). On the other, as Polaschek (1958) observes, its primary value actually lies in the information it gathered which could be used during the atmosphere it created that "helps to keep administration in line with public opinion". This is acknowledged by Jackson himself as well as other commentators (Jackson 1987; McRobie 1978; Palmer 1979). In other words, the financial process provided another channel for parliamentary scrutiny of and influence over the 
bureaucracy, which is particularly valuable in the face of executive dominance $^{16}$.

Yet the effectiveness of parliamentary scrutiny as a whole must be questioned. Central to the issue was the traditional culture of secrecy. Under the Official Secrets Act 1951, public servants were required to sign a declaration and gave an undertaking that they would not disclose official secrets. And the duty to be free and frank, alongside the supposed need for anonymity, reinforced the tendency to withhold information. Ministers too were bound by the convention of cabinet confidentiality, which added to the cloud of secrecy. It is also true that the adversarial nature of a Westminster system put a premium on information, which acted as a further disincentive to openness. (It could equally be argued, however, that it is a positive incentive for opposition members to seek information.) It is important to note that the origin of official secrecy lies not in Parliament but in the prerogative of the Crown that predates it (Eagles et al 1992). Yet whatever its origin is, the culture of secrecy and the (Weberian) bureaucratic power were mutually reinforcing ${ }^{17}$. And in New Zealand there had been official attempts that chipped away at the culture of secrecy prior to the Official Information Act ${ }^{18}$ (Keith 2005). Nonetheless the assumptions of official secrecy - that information is secret unless made publicly available - gave the bureaucracy an automatic claim to power and put politicians at an instant disadvantage.

\footnotetext{
${ }^{16}$ It must be pointed out that the Public Accounts Committee and Public Expenditure Committee were themselves dominated by the Executive.

${ }^{17}$ For Weber, of course, the concept of official secrets is "the specific invention of the bureaucracy". This could be regarded as a reflection of different political histories.

Whereas in Germany the bureaucracy became almost synonymous with the state since Fredrick the Great and intimately connected to the Monarch, the question of secrecy was raised earlier in Parliament's attempt to control the Monarch, which predates the rise of modern bureaucracy. Nonetheless, this does not change the fundamental relation between secrecy and power.

${ }^{18}$ Keith (2005) writes that "notwithstanding the strictures of the Official Secrets Act, or really by way of recommending a relaxation of them, the Royal Commission on the State Services declared that "Government administration is the public's business, and the people are entitled to know more than they do of what is being done and why". That declaration led to the newly established State Services Commission directing in 1964 that the rule should now be that information should be withheld only if there is good reason for doing so.' The administrative directive was not successful however.
} 
The passage of the Official Information Act 1982 (OIA) through this lens is to be regarded as a confirmation of the spirit of the Westminster system rather than an attack on it. It is true that the legislation required "an overturning of the traditional way of doing things", but it does not necessarily conflict with the other parts of the Westminster system, such as the doctrine of ministerial responsibility or the requirements of free and frank advice, and therefore "move by backdoor towards the American system of government", as John Martin feared (1988:45). Indeed the problem of the Official Secrets Act is precisely that it reinforced bureaucratic autonomy by insulating its claim to power against Parliament. The passage of the Official Information Act therefore simply confirmed to the correct constitutional principle, that such powers should be exercised only with Parliament's consent and that Parliament should have unfettered right to information if it so wishes. Parliament, of course, can still choose to protect the confidentiality of official advice, as it did in the OIA, but the point is that secrecy is no longer solely a prerogative of the Executive. It is not surprising then that the OIA had been used extensively by opposition politicians and the media. Information is a powerful political weapon. And this inherently political nature might also explain why a recent evaluation has found mixed views on the effectiveness of the legislative framework ${ }^{19}$ (White 2007). Because it is political, as Gregory (1984:15) predicted in the early years of the OIA, the OIA was "neither panacea nor placebo".

The Ombudsman is another innovation under the traditional model, which altered the balance between Parliament and the bureaucracy. Although its adaptation in New Zealand had required adjustment (Gilling 1998), it did not pose significant constitutional difficulty. After all, the creation of the office in Sweden sprang from the Swedish Parliament's struggle with the Crown. A similar struggle had laid the foundation of the Westminster system. The working of the Ombudsman reflects its status as a parliamentary officer and indirectly the way Parliament exercises its

\footnotetext{
${ }^{19}$ White's research had found that much of the dissatisfaction with the OIA stemmed from the perception that the operation of OIA has been too 'political', instead of merely shining a light on official actions (White 2007).
} 
authority in a Westminster framework. Information again was the key and the Ombudsman was given almost unfettered access to official papers, despite the stricture of the Official Secrets Act. It has the power of persuasion and advocacy on behalf of citizens but no direct control over the bureaucracy. Yet, in spite of this lack of control, the Ombudsman today is recognised as almost universally a success, even in comparison with the Courts (Palmer and Palmer 2004; Keith 2005).

The Official Information Act and Ombudsman had strengthened Parliament and compensated for the effects of majoritarianism. However these two innovations alone could not, and did not, address the problems at its root. Despite its promise and potentials, parliamentary sovereignty remained very much an illusion.

\section{Accountable but not Responsible?}

Under the traditional model, the convention of ministerial responsibility was the central means to ensure accountability, and responsibility, for bureaucratic actions. The traditional notion of ministerial responsibility means, according Scott (1962:124):

A minister has not only primary responsibility for his own actions but also vicarious responsibility for the actions of his [sic] subordinates...Where the actions of departmental officers have been done on the minister's bidding, the minister's responsibility is vicarious only. In practice a minister always admits that he is responsible for the actions of his subordinates in the sense of being accountable for them.

A brief look at the operation of ministerial responsibility under the traditional model might easily give an impression that ministerial responsibility, though a central constitutional doctrine, was more honoured in the breach than the observance. In 1980 Keith Ovenden argued that the 
correct interpretation of the doctrine had already been "lost" and "largely in response to this loss the convention has been allowed to die" (Ovenden 1980:95).

To make a case for the death of ministerial responsibility - assuming that there was a time when the doctrine was "alive and kicking" - one cannot escape referring to Bob Semple's famous, and often misunderstood, dictum that "I am responsible but not to blame". The Semple case has been widely cited in New Zealand literature. It is appropriate therefore to discuss the doctrine against this practical example.

The first thing to note about the traditional doctrine is that while who to blame is usually a difficult question, who is responsible is not, because the ultimately responsible persons can always be traced through the chain of command to the Ministers and ultimately to the Prime Minister and the government. Admittedly, the classical interpretation of the doctrine, such as Scott's version above, which distinguishes between the personal and the vicarious, could easily lend itself to a "causal" rather than "role" notion of responsibility along Woodhouse's typology. However, unlike the policy/administration divide, such a distinction was not made with any presumed precision. What counts as reasonable and what could have been done differently are after all speculative questions for which Scott provided no answers. The doctrine therefore, could be understood as a "backward mapping" strategy (Boven and t'Hart 1996; 62-3): it requires Ministers to fulfil their role and take responsibility first and from there the exact extent of the responsibility is worked out through the political process.

This understanding of what Ministers are responsible for is illustrated by Bob Semple when he states very clearly that

Of course, we are responsible; of course I am responsible for the administration of my department; I am responsible for the administration of my department; I am responsible for the conduct of 
the servants too; but I am not to blame for things they do that are wicked and contemptible (NZPD 18 October 1944).

Here Semple did not seek to blame the permanent head, nor "the system", by distinguishing between the responsibilities of the minister and the department. His defence instead rest on the matter of trust between the Ministers and individuals whom he alleged had betrayed his trust. To him and the opposition, it was clear that Ministers have a role to play in the administration of the department, and consequently a duty to inform Parliament and public of the potential problems that he should have known and could have rectified earlier, whether or not the actions or inactions of politicians actually caused such problems. The question is whether he had failed in such a role, not whether such a role exists. Thus, had the traditional notion of ministerial responsibility really meant a causal notion that separates between administration and policy, it would be very difficult to explain why Semple would have chosen such an awkward way, if he intended to shift blame to officials, instead of appealing to the separation from the beginning. The fact that this route was not taken demonstrates the strength of doctrine as a powerful political symbol, which could not be easily set aside.

Secondly, the Semple case also illustrates how the doctrine was supposed to work. Most commentaries focused on the debate which took place in October. The issue had actually already surfaced in March. At that time, the Leader of the Opposition, refuting accusations against Semple from his own colleagues, commented that

I and the honourable member of Stratford here had lengthy discussions with the Minister of Works [Semple] on this question. I asked that files be made available and the Minister has said that I can have any file at any time. I spent a considerable time with him and I have read the report and I would be failing in my duty if I did not say that I do not think the Minister is personally responsible (NZPD 25 March 1944) 
This shows, in a sense, the constitutional minimum: Parliament, especially the Opposition, with the assistance of the Minister, was able to reach into bureaucracy, investigate the errors and arrive at its own conclusions. This requirement was met without much fanfare. While the fact exonerated Semple - a Commission of Inquiry had confirmed that - the debate did not stop there, which made the degree of openness on the part of the Minister even more remarkable. Rather it marked the beginning of a more difficult and less certain political process through which the political questions around responsibility in its broader sense could be examined in more depth, even if a simple clear-cut answer can never be reached. If one were to focus on facts alone, the Semple case would probably not have received as much notoriety and concepts such as "systemic failures" might have to be invented to explain the failures in the construction of the tunnels.

The use and misuse of the Semple case usually impinge upon the proportion of blame. Even if one were to view Semple's claim as a cynical attempt at blame shifting, and even if one were to discount completely the cost of accountability and remedial requirements which he did fulfil, Semple did not exactly go "scot-free". In the first place, Semple's statement did not conclude the political debate of where blame lies. Indeed the fact that Semple did not resort to any argument on the point of principle, such as the politics/administration dichotomy, but rather a "weaker" case of trust, exposed his defence to political judgment. As a result Semple had to withstand the sustained scrutiny from the Opposition and the negative publicity that ensued, not to mention that for some he still carries the can for supposedly undermining the constitutional doctrine. On top of that by coming to Semple's defence the cabinet and the Prime Minister, in effect, took the responsibility (McLeay 1995). These political costs are by no means negligible.

The problem is that blame is often confused with responsibility. Such confusion tends to lead one to overlook the political cost and focus on 
symbolic punishment, such as resignation. In the Semple case, the Minister did not resign. For one thing, who should bear the blame was hardly straightforward in the Semple case. For another, forcing resignation was never impossible, since Semple had accepted the responsibility for administration, so long as the opposition could argue convincingly that the minister had failed in his administrative duties, and had not simply been "betrayed". And the willingness of Ministers to take full responsibility for departmental actions actually paved the way to such demands for resignation. It would have been much harder to argue for resignation, if the Ministers were allowed to flatly reject responsibility simply because the causal evidence was weak. Moreover, it could be argued a swift resignation of the minister might well be counterproductive even for the Opposition since it would enable the Government to escape its share of criticism, as it did in the 1934 case, which saw the resignation of Sir Apirana Ngata for departmental maladministration and alleged corruption (Scott 1962:121).

Finally, the traditional model is often linked to accountability in its procedural and mechanic sense i.e. accountability for following rules. It would be difficult however to identify such a link in the Semple case. While whether correct procedures had been followed was inevitably part of it, the focus was with what could be best called, with an unavoidable ambiguity, departmental administration. Moreover, for Semple, his defence rests heavily on the issue of trust, which lent to the accountability debate a personal and relational dimension. This would have been quite unnecessary with a mechanical and procedural conception of responsibility.

More broadly, the doctrine of ministerial responsibility simply does not seek to prescribe the "what" of accountability, and certainly does not require a fixation on inputs. Rather, as Scott (1962:132) points out,

The category of the duties of Ministers is not closed. Ministers are defensively responsible whenever the opposition criticises them, and 
the government party is responsible in its own interests for answering any criticisms.

This would probably appear very odd for commentators today who are obsessed with tying accountability to specific concepts such as inputs, outputs and outcomes, or individual and collective causes, which are necessarily partial and incomplete snapshots of bureaucratic actions. Neither does the formulation of ministerial responsibility depend on the existence of causal linkages. Rather, it seeks to capture something more fundamental, that is, the exercise of power that underpins everything that the bureaucracy does and which ultimately emanates from the Ministers themselves.

The exact form of ministerial responsibility "can take on as rich or as spare a meaning as parliamentary antagonists want them to mean" (Uhr 2005a:12). This flexibility is important because it reaffirms the constitutional relations between Parliament and the executive. As Scott (1962:121) puts it, "the concept of responsible government entails the existence of an unfettered discretion in Parliament, not only as to the actions for which a minister or Ministers may be held responsible, but also as to whether responsibility is to be attributed to a single minister or to the ministry collectively". The decision as to what could be properly asked of ministers is one for Parliament itself to make, rather than relying on any external criteria.

The supposedly worst-case scenario of ministerial responsibility in the Semple case thus was not as bad as it might appear at first sight. The Semple case was not an isolated example of course. In 1955, the justice minister of a National Government also faced the same dilemma in a prisoner escape scandal (Mcleay 1995:195; Robson 1987). The minister also accepted full responsibility in the first instance ${ }^{20}$. Politicians were

\footnotetext{
${ }^{20}$ The Minister, John Marshall's press statement at the time presents a classical interpretation of ministerial responsibility. He stated that 'I have no wish to evade responsibility or a single aspect of this inexcusable happening, for which, as Minister now
} 
generally prepared to take responsibility for their own actions and their departments' actions and, even though resignation is not required, face the political consequences for doing so.

However, the problem is that the working of ministerial responsibility presumes a vigorous democratic political scrutiny, which was as argued above, critically undermined by the culture of secrecy and majoritarianism. In a way the chief strength of the doctrine of ministerial responsibility - its link with politics - is also its major weakness. This makes it easier to depart from constitutional norms. This happened in 1984 when the Ministers of the National Government openly blamed their departments for the failures of the Maniototo irrigation scheme (Roberts 1987:48-49). The correct interpretation of the doctrine would require them firstly to take the responsibility for the administration of the departments themselves, presumably also to defend their departments, and to identify individual officials who they believe were to blame. These differences are subtle but nonetheless important. As Roberts points out, this case alone does not change the constitutional rule. The constitutional shift however was not very far away, as the Cave Creek tragedy discussed below will show.

in charge of the administration of prisons I bear responsibility. I have sought to discharge this responsibility by giving a full account of the case and by indicating as clearly as possible the steps which have been taken to avoid such cases.' Marshall did not resign, nevertheless. 


\section{$\underline{\text { A different kind of servants }}$}

To understand the role of public servants in the old public service, it would be useful to remember that there was a time in the history of New Zealand's public service when officials were servants and such a notion of officials as servants never entirely vanished (McKinnon 2003:51). Indeed, this notion of ministerial-official as a private employment relationship was to be revived in the 1980s. The reform in 1912, by abolishing patronage, changed all that, however. The bargain between Ministers and officials was no longer a private transaction. Officials were still called servants, but they are now public servants. And this "public" orientation puts a wholly different complexion upon the relationship between Ministers and officials.

This relationship is often described as a "Schafferian" bargain (Hood and Lodge 2006). In New Zealand Lipson (1948:479) expresses a similar idea that:

By guaranteeing to public servants a life's career and a pension, parties have foresworn the use of patronage and have guaranteed to the state's employees their tenure of their jobs. In return the parties expect, and the public servants owe, equal loyalty to any government, which the people have placed in place.

Political neutrality was clearly central to this bargain. But what exactly did neutrality mean in the traditional bargain? One view was that it implied the discredited separation between politics and administration (Mallard 2003). This is certainly a simple explanation but not a very convincing one. For one thing the idea of a functional divide, which had its origin in America, was more compatible with a separation-of-power constitution - at any rate it has long been rejected by American commentators themselves (Lynn 2001) - than Westminster norms. It would not fit easily with the idea of parliamentary sovereignty and ministerial responsibility, both of which 
imply the prerogative of politicians to reach into bureaucracy itself, if they wish, rather than steering from the outside. It is doubtful whether such an idea had ever taken root in New Zealand, beyond perhaps a few confused references (the report of a 1934 Commission of Inquiry on Native Affairs was one example). Although some officials had been fond of laying down such principles, Leicester Webb observed as early as 1940, a separation 'between policy and administration, between the functions of the minister and his [sic] high officials' would be "unreal" (1940:88). In any case, as Smith (1974:111) argues, it had already become commonplace to dismiss the dichotomy as a myth.

The reality was certainly very different, and this could be easily seen in the early commentaries on public administration. Whether it is because of the small size of New Zealand or other reasons, the principle of anonymity was never quite as strong or practical as in countries such as UK. This helped to highlight the prominent roles that public servants such as Tregear $^{21}$ or Beeby played in policies of the emerging Welfare State. Their relationships with politicians were more close to a partnership devoted to similar goals than that between a superior and the subordinate. More often, the traditional role of senior public servants was a fusion between politics and administration: "as advisers to elected Ministers and as senior executives of the department or bureau" (Martin 1988:26). The provision of policy advice was inevitable, which often had a direct impact, and such advice was inevitably, as one seasoned public servant noted in 1957, "political in the best sense of the word" (Marshall 1957:128). The policy/administration line was not only blurred at the top, it was also challenged from the bottom by a general awareness of the inevitability of administrative discretion and the discretionary powers exercised by officials (Milne 1957; Polaschek 1958). Public servants themselves were acutely aware of not only the political environment in which they worked,

\footnotetext{
${ }^{21}$ Edward Tregear (1846-1931), Secretary of Labour from 1891 to 1910 , was responsible for the progressive industrial legislation passed under the Liberal Government. Clarence Beeby (1902-1998) was the Director of Education from 1940 to 1959 who was instrumental in founding New Zealand's modern education system (Dictionary of New Zealand Biography at http://www.dnzb.govt.nz).
} 
but also the dual roles of implementing as well as formulating the policy, as Smith (1974:113) found in his survey. Smith quotes one administrator that "Anyone who thinks that the government is not influenced by politics is naïve in the first degree". All these point to an awareness of "the political nature of administration" that transcends the artificial politics/administration divide despite such nature being "particularly well hidden" (Wilenski 1980:23). "Politicisation" was already there. The logic of the bargain was not separation between politics and administration, nor to trade the two off, but rather the subjugation of administrative power to political power.

But this does not mean that New Zealand's public servants were not neutral. Rather, it simply suggests that they did not mistake neutrality for being "apolitical". Smith (1974:111-112) for instance emphasizes the distinction between politicisation and partisanship. He also found that, while New Zealand bureaucrats were aware of the political aspect of administration, "there is a clear indication that the administrators are nonpartisan in their relationship". There was no question that political neutrality was central.

To define neutrality is a slightly more difficult task. Broadly and vaguely it meant the timeless terms that public servants should serve whoever the people put in government "with the same loyalty and professional services as its predecessors" (Probine 1963:22). Absence of political patronage was the bottomline and was generally respected. And it is interesting to point out that this had never been intended to mean that Ministers' views on candidates should be entirely ignored (Scott 1962: 138-9). Beyond this however the view of neutrality differed. James (2002) believes that the traditional doctrine required public servants "not to carry out instructions to promote the minister's party or engage in party political activity". Scott (1962: 140), by contrast, preferred an emphasis on the "serial loyalty" - a view which is shared by John Martin (1988). He argued that the Ministers' intention should be left to the electorate to judge and public servants were to serve the Government loyally even when they suspect the policy had been adopted only for electoral reasons. Such disagreements are 
unavoidable. What "partisan" politics is, ultimately, must be a matter for political judgement, rather than the personal judgement of public servants themselves. In this sense the disagreements simply reflect the political nature of neutrality. But Scott had gone too far in that he overlooked his interpretation, which he had admitted as being "extreme", relies on the presumption of an almost ideal democratic process, which simply was not the case in New Zealand's "elective dictatorship".

Despite difficulties of precise definition and prescriptions, public servants nevertheless managed under the traditional model with a pragmatic attitude. This gave the principle of neutrality another interpretation, which conceived neutrality as an essential ingredient of sustained trust between Ministers and officials, rather than an injunction against "politics" (Probine 1963:24). A high degree of trust, Probine argues, is in the interest of individual public servants as well as the interest of Government, the Opposition parties and the country as a whole.

Trust was gained, rather than assumed. It was, as Roberts (1987:83) puts it, "battle honour won in a stern campaign... preserved only by correct behaviour". Indeed a number of commentators have found in New Zealand a culture of mutual suspicion between public servants and politicians both left and right - which often came to the spotlight when there was a change of government (Polaschek 1958: 224, 286; Martin 1988:15). Nonetheless there is very little evidence that the initial reservation actually led to persistent problem or crisis. According to Martin (1988), in two significant moments - election of the 1936 Labour Government and the 1949 National Government - transitions were made without much friction. Neither was there any hard evidence, one must add, that adherence to neutrality has actually eliminated the tension. Nonetheless, what one could draw from these experiences is a compelling argument that the principle of neutrality had stood strong against the odds.

The principle of neutrality was reinforced by a strong sense of loyalty. Deference to politics was still the accepted norm. Open conflicts between 
officials and politicians were rare. The majority of public servants, Smith (1974) found, rejected more authority for them in policy making and instead preferred to see the politicians running the show. This is not to suggest that tensions did not exist. The McCarthy Comission (1962) for instance was compelled to state "the obvious", while commenting on Treasury's power, that "it is Cabinet or the Minister, not Treasury, that makes the decisions. Treasury is merely an advisor". Nonetheless, as Polasheck (1958:210) concluded, while political control was never a perfect safeguard, "politicians touch the key points and are remarkably successful in bending the Service to the wishes of the people".

Deference to politics does not mean subservience. Rather the convention of free and frank advice was equally valued as part of the loyalty bargain. Scott (1962:142) demands that

where a permanent head thinks the minister is wrong about the merits of a policy, or wrong in allowing himself to be influenced by considerations of political principle or of political interest, he owes to his minister to say so. He owes the duty of offering disinterested and fearless advice, and should argue as strongly as he feels is justified. But he should not necessarily argue the matter repeatedly.

Smith (1974) similarly found that officials valued the ability to "stand up to politicians". While this may have been a strong norm, it is difficult to assess how it is applied in practice, because of the confidential nature of official advice. Perhaps the most clear example was decision of the 1948 National Government to abandon its policies of abolishing price control based on official advice, despite the fact that those policies had been part of its election platform (Scott 1962:143). Yet one could also discover the darker side of the art of "speaking truth to power", for instance, in the advice tendered by Treasury to the Labour Government on the 1958 
"Black Budget", which had been politically disastrous for the Government (McKinnon 2003). ${ }^{22}$

But confidentiality was not simply a symptom of the culture of secrecy. Rather it was a necessary part of the bargain. It required Ministers to take political responsibilities for their decisions and refrain from attacking the officials in return for the latter's public commitment to the final decision.

In return for their public silence the Ministers are to take responsibility for their decisions and refrain from attacking their officials. This as argued previously did not always happen. Apart from the Maniototo scheme mentioned above, an earlier instance occurred in the early 1950s when the Minister of Maori Affairs in 1954 openly criticised his department for failing to carry out the government's policies (Scott 1962:132). ${ }^{23}$ It is not necessary to recount the detail of the case. But nonetheless it is worthwhile to emphasize the interconnected nature of constitutional conventions, if ministerial responsibility has failed, then the traditional bargain is likely to remain weak too.

Similarly from the politicians' point of view, officials sometimes broke the bargain too, for example, by leaking or "whistling blowing", notably regarding debates on issues such as indigenous forestry policy in the 1970s because of differences in political views. It led the State Services Commission to reiterate the duty of loyalty (Boston et al 1996; Martin 1988). As James (2002) points out, quite correctly, there were probably no fewer leaks in the days of the old public service than in the 1980s or 90s. But there are qualitative differences, as a result of a different context. The writing of contemporary commentators clearly reflects a prevailing

\footnotetext{
${ }^{22}$ As one economist recalled, Treasury's strategy was to deliver a "fiscally responsible" budget, but "framed" around the policies that the Labour Government had promised. As a result it left the Government little choice but to "put up indirect taxes - [but] on things that were politically disastrous for Labour" (Holmes quoted in McKinnon 2003:220).

${ }^{23}$ Scott points out that the Minister "had made no complaints either generally or specifically on which disciplinary or remedial actions could be based", and even if he "had conveyed his complaints through the proper channels, he was at fault of not ensuring that remedial action was taken" (1962:132).
} 
aversion against breaking the bargain except in extreme cases. While it could be assumed that such opinion was shaped by its time, the argument itself is not necessarily outdated. For the justification of leaking/whistleblowing inevitably falls back on the issue of "public interest" versus obligation as a public employee. The heart of the argument, as Scott puts it, is that

it is a matter of opinion where the public interest lies...the case for giving political power to Ministers in a parliamentary democracy is not that they can be always guaranteed to know with a mechanical perfection where the public interest lies, but that they are responsible' so our constitutional system is not subverted by the errors of judgement that Ministers, being human, are bound to make, but is subverted by the obstruction of ministerial wishes by politically irresponsible public servants (1962:141).

Polaschek's argument (1958: 223) was not entirely dissimilar. He was concerned that this practice might allow public servants to acquire their own source of influence from pressure groups, which "strikes at the very basis of the democratic control of the public service". As Polasheck points out, officials cannot be "divorced from the power and authority of his [sic] official position". In other words, the issue for Scott and Polasheck is not simply about loyalty to politicians but rather the need to maintain democratic control over bureaucratic power through such a bargain. However again the force of such arguments depends critically on the quality of democratic control. With hindsight, they might have been too restrictive, given the dysfunctional democratic process and the lack of alternative means of internal disclosure. Yet these may actually provide some useful insights into today's problems, as well be discussed later.

The traditional bargain between Ministers and officials, therefore, produces similar dilemmas as the other two elements of the constitutional system. On one hand, there was a strong culture of political neutrality and loyalty within the public service. On the other hand, the bargain itself was again 
stretched to the limits directly and indirectly by the dysfunctions of the oppressively secretive majoritarian political system.

Constitutional control of the public service, while effective in theory, was limited in reality. And this adds to the problem of the public service itself, torn between the hazardous forces of classical Weberian bureaucracy and welfare professionalism. Reforms were necessary. But did the reformers of the 1980 s make all the right steps? 


\section{A Brave New World}

\subsection{The Rise of the New Right}

As Wendy Larner (2000) points out, there are "different versions of neoliberalism". Nonetheless, at the risk of simplification, the radical changes to New Zealand's political landscape during the 1980s and 90s brought about by the New Right still are recognisably neo-liberal, in spite their differences and apparent contradictions.

Indeed, what is peculiar about the New Right is its ability to hold together different, and potentially contradictory, values while suppressing precisely these contradictions. Classically the New Right was seen as an expression of libertarian values such as negative liberties, sanctity of contracts and property rights. This does not mean that the New Right presumes the validity of the market, or privileges economic profit above everything else. Rather, it is better understood as an ethics or ethos that constructs and construes values in rational market terms (Brown 2003; 2006). Thus it is not surprising that equally central to New Zealand's New Right agenda was an emphasis on "moral rectification", with its own variant of Thatcherite "Victorian" values: "core family", private charity, thrift, and decency, the evil of dependency, the importance of self-help, the appropriateness of incentives, and the moral imperatives of entrepreneurship. Not only are consumers free to choose, it was made certain that they could not do otherwise. They "should attend to their own needs" and are "expected to meet the cost of their social services themselves" (Richardson 1990:20). The individual freed from Fortress New Zealand was in fact heavily disciplined by her or his own freedom. In a sense, the abortive Code of Social Responsibility introduced by the National Government in 1998, which attempts to prescribe the responsibilities rather than rights of citizens, represents the high point of the New Right project. That is a project "of extending and bolstering market logics, socialising individualised subjects and disciplining the 
noncompliant", if only to bear out its contradictions (Peck and Tickell 2002:42).

The complexity of New Right values certainly demonstrates Larner's point. What holds these values together, however tenuously, is above all their rather fevered - and one may argue deeply irrational - desire for value certainty in an age of uncertainty. Perhaps nowhere is this mentality more pronounced than the idealisation of the colonial past in such influential works as that of David Green. For New Zealanders in the 1990s, as Thomson (1990:165) puts it, colonial society was not only "what lies behind but also ahead". It was not so much that the values themselves fitted together, but that they both fitted into this notional past in one way or another. The notional past, with its powerful suggestion of stability and harmony, seemed to provide a way out of present contradictions and away from politics. The economic fundamentalism of the New Right was not so much economic as fundamentalist.

Accompanying the changes in values was a reconceptualisation of the idea of social relations, which under the welfare state manifested itself in the concept of citizenship with a right to welfare. Under the New Right, such a concept gave way to the images of "consumers" and "competitors" (Janiewski and Morris 2005). The implications of such a shift for politics seemed clearly borne out in practice. To quote Helen Clark, then Minister of Health in 1989, "I have tried very hard to think of words other than consumers, but I can't ... in the end I come to the conclusion that we can probably only all be described generically as consumers of the health system" (James 1992:139). These words from an unlikely ally of the New Right ideology demonstrate its penetration into politics.

This partly explains the preoccupation of the reformers in the 1980s and 1990s with economic policy while social policies "suffered from prevarication if not simple neglect" (Holland and Boston 1990; Rice 1992:485). There was an apparent disjunction, but not a real one: after all both are policies made for and affecting people in society. "Economic" 
reforms, such as the flattening of tax scales, struck right at the heart of the social compromise embodied by the welfare state. It would be more accurate to talk of the dominance of economic priorities over social ones and the reframing of social issues in terms of "what we can afford", measured by the rate of spending against GDP, rather than what matters most to the public (Boston et al 1999b).

Framing the debate in these terms, the economy, it was argued, was under severe stress, particularly because of mismanagement during previous years (Treasury 1984; Aberbach and Christensen 2001). A similar rhetoric of crisis was used by the National Government to justify its own "structural adjustment" in the 1990s. Arguments such as these are open to debate (Goldfinch 1998a; 1998b; 2000; 2004a). At the same time the talk of crisis often tended to foreclose careful discussion and opened the way to the introduction of "econocracy" in New Zealand, the essence of which is an appeal to theoretical or technocratic knowledge (Gregory 1998b). Indeed, Aberbach and Christensen argue that the reform could be theorised using a "garbage can" perspective: the exact nature of the problem does not matter much, rather, what matters are the ready-made solutions.

Of course the technocratic tendency is also apparent under the neoKeynesian paradigm of "economic management," as Gregory (1998b) points out, and therefore has a similar tendency to a "garbage can" mentality. The problem, however, was that while the neo-Keynesian paradigm at least retains a notion of managing the economy to improve welfare and thus is open to the political questioning of "welfare", the neoclassical model views the economy as a central part of its alternative and autonomous "regime of truth" to politics. The neo-Keynesian means-ends formula was inverted: now the most important task became to manage social policies to provide "a consistent framework for the growth and development of a strong economy" (Treasury 1987:374). Pains inflicted upon some sections of society, usually the disadvantaged, were therefore justified for the sake of gains to "the economy". 
The third factor in this technocratic transformation is the changing approach to politics ("Rogerpolitics" Mulgan (1992b) or "Blitzkrieg" (Easton 1997)) which "involved an attack not only on the democratic conventions of the Westminster system but also on deeply held values within New Zealand's political culture". Of course, changing ideological commitments must necessarily be reflected in new institutional arrangements and values. This is precisely what makes the choice of structure important: it is not simply a matter of means, but rather essentially a question of political ends.

The principles of this new approach to politics seem to have a particular authoritarian bent. Yet the obsession with speed or efficiency is not inconsistent with the New Right spirit of entrepreneurialism. Taking "quantum leaps" - rather than limited, "strategic," consultative, one-stepat-a-time, reforms - outflanking opponents by rapid implementation, as laid down by Douglas (1993:217-218), is not only tactical, but also embodies the morality and rationality of a competitive market, where consumers are lured and supposedly satisfied by finalised commodities, and competitors are to be eliminated at all cost. This is not just a variant of politics. It is a replacement of the primacy of politics with the primacy of the market.

Moreover, along with the market view of politics is a deep distrust of others in the political community, reinforced by Public Choice theory, shared by reform-minded Treasury officials and politicians. Opponents to reform including those within the bureaucracy - were pre-emptively dismissed as the voices of vested interest or "privilege" and accused of "capture", although proponents were deemed to be curiously exempt from such blanket allegations (Goldfinch 1997). A cynic might suggest a self-serving logic at work. But perhaps the deeper problem lies in the impossibility of public servants being "just technicians applying value-free scientific analysis to society and welfare for all" (Goldfinch 1997:72). 
In addition, the reform was driven by "a close (and often relatively closed) trust and reciprocity policy community" (Goldfinch 2004:89; also Goldfinch 1997; Gregory 1998b; Janiewski and Morris 2005). Such an elitist tendency seems almost to have reversed the processes of the preceding era, by replacing generalised trust distilled from the pluralistic democratic process with localised trust based on certain values and relationships.

Power was concentrated in the hands not only of political and bureaucratic actors but also private organisations such as the New Zealand Business Roundtable and the Centre for Independent Studies ${ }^{24}$. Contestability and flexibility outside the political realm seems to produce an even narrower coterie of decision-makers in the economic world.

To put the above analysis in another way, the politics of the New Right were not politics at all, bur rather a form of 'anti-politics". Such "antipolitics" was based on values not open to debate and projected a reified universe where human autonomy and equality can be sacrificed for other "things". And it reduced politics to no more than expedient means to technocratic ends. In these terms, it could be argued that the New Right had "bureaucratised" politics in a Weberian sense.

\subsection{The New Public Management Model}

The New Public Management reform was integral to this counterrevolution. In New Zealand the reform was driven by a set of coherent and highly dogmatic, as well as technocratic, economic theories - particularly Public Choice, Agency Theory and Transaction Cost Economics - which are intimately connected to neoliberalism and neo-classical economics. The perceived economic crisis and the changing politics allowed the reformers to seize a rare window of opportunity to "crash through" with these theories in a purer form in New Zealand than elsewhere (Aberbach

\footnotetext{
${ }^{24}$ The Centre for Independent Studies is a libertarian think tank based in Australia, but had crucial influences over the New Zealand economic reforms during the 1980s and 90s. It has a New Zealand office opened in 2005.
} 
and Christensen 2001; Gregory 1998b; Goldfinch 2000). The resulting New Zealand model is widely regarded as an exemplary application of NPM (Boston et al 1996; Pollitt and Bouckaert 2004; Chapman and Duncan 2007). Whereas neoliberalism chooses the Welfare State as its enemy, the target of NPM is the "bureaucratic" public service of the old Welfare State. To what extent then did NPM succeed in debureaucratising the state?

\section{Managers or Mandarins?}

A central tenet of the NPM reform is what can be called "managerialism" (Pollitt 1993; 2003). The process of managerialism can be summed up with the slogans: "free managers to manage" and "make managers manage". The first slogan means "shifting decisions on the use of resources (staff, money, space, supplies, and so on) from central controllers and headquarters staff to line managers". The second refers to "specifying in advance the performance expected of them, comparing results against targets and auditing both financial and substantive performance" (World Bank 2000:36).

In New Zealand, the implementation of managerialism, through the State Sector Act 1988 and the Public Finance Act 1989, entailed radical changes to the traditional model of public service. "Chief Executives" employed on five year renewable fixed-term contracts replaced "permanent heads" as the top officials of the departments. They were given authority over staff employment and pay, as well as greater freedom to manage financial resources, or "inputs" in the NPM vernacular, so that they could, among other things, "recruit others who are willing and able to take charge" and "shed workers who shirk responsibility or are unproductive" (Schick 1996:41). They were encouraged to be "robust, entrepreneurial, risk taking" (ibid.). In return they were bound by performance agreements with their ministers, which specified the "results" or "outputs" - the goods and services produced by departments (including 
policy advice) - that they were required to deliver ${ }^{25}$. This was supported by the ex ante specification and ex post reporting of departmental performance in delivering outputs, through a "modernised" budgetary system based on accrual accounting and aligned with generally accepted accounting practice (or GAAP). This system provided for "purchase agreements" with ministers as purchasers and CEs as providers or producers, which reinforced the responsibility for delivery of outputs (Boston et al 1996; Goldfinch 1998a; Norman 2003; Schick 1996, 2001; Scott 1996, 2001).

These changes served New Zealand public servants with a stern message: they could no longer be "bureaucrats" or even professionals. To enjoy the freedom promised by a new regime they must become managers. Just like the individual citizen in a neoliberal society, the public manager was to be controlled through her or his freedom. The point of NPM, in the words of its advocates, was "to give away control of small numbers in exchange of control of large numbers" (Scott 1996:89).

The justification for, and the central value of, a better managed - or better controlled - public service is that it would improve efficiency and effectiveness (Scott 2001). Norman (2003) likens the pursuit of efficiency and effectiveness to "the quest for Holy Grail" (more Monty-Pythonesque than biblical perhaps? - author). As many commentators have pointed out, in practice, the emphasis falls on the former - in the economic or operational sense of more outputs for less inputs - rather than the latter (Boston et al 1996; Schick 2001). It is generally acknowledged that managerialism had brought some efficiency gains - for example the length of time required to obtain passports was significantly shortened - even by the critics of the regime (Gregory 2001; Kelsey 1995; Petrie and Webber 2001; Scott 2001). Overall efficiency gains were much more uncertain,

\footnotetext{
${ }^{25}$ A SRA/KRA system was implemented in 1993 by the National Government. The KRA or key results areas replaced 'outputs' as the focus of performance agreements. The move reflected concerns about the lack of attention to 'strategic' results or outcomes. This issue will be discussed below.
} 
particularly given the costs of the reforms themselves such as spending on consultants and extravagant severance payments for senior officials (Goldfinch 1998a; Gregory 2001).

Issuing passports and processing benefit payments are not the same as guaranteeing the rights of citizens, however. A narrow focus on instrumental efficiency may increase the probability of "hitting the target but missing the point", given the multiplicity of objectives that characterise a public service (Boston et al 1996; Gregory 2001; 2007a). In this light, NPM can be seen as a case of bureaucratic "goal displacement" where quest for efficient means became an end in itself (Gregory 2007a).

But this simply begs the question as to why NPM managed to transform the public service at all. The fact is that NPM was introduced at a time in New Zealand when the various and contradictory objectives of the Welfare State that stood in the way of business-like efficient management were under siege. In the neoliberal world there is simply no such thing as "public interest" that can or needs to be undermined. It is not just the public service, but also the "publicness" of it, that has come under attack (Haque 2001).

The issue here is not simply about the boundary between the public and the private. Such an argument has proven to be an easy target for NPM theorists (see Scott 2001:37). As Boston et al (1996:39) observes, "it was never assumed by those guiding the reforms that private sector management practices should be applied automatically, uncritically, or comprehensively to the public sector". Rather NPM is better understood as a fundamental re-definition of the "public" itself than simply as an encroachment of the public by the private. It did not escape those attentive private managers that in some cases managerial freedoms for public managers compared favourably with those of large companies, provided policies, rules and guidelines are followed (Norman 2003: 83). 
This subtle but profound transformation from within can be seen in "the emergence of a managerial elite enjoying highly privileged rates of remuneration (including in some cases massive severance payments), which have been increasing much more quickly than those of the rank and file", that signalled the end of egalitarianism that the New Zealand Public Service had traditionally embodied ${ }^{26}$ (Gregory 2000; 2002a; 2002b). In other words, it is the transformed political context that made possible a stronger commitment to the bureaucratic quest for efficiency than the previous system could allow.

Efficiency can be obtained by means of apparently quite different ways. The NPM reformers have often contrasted the flexibility of management with the "culture of compliance" of administration bound by procedural rules and input controls (Schick in Scott 2001:xv). Such a comparison is superficial and misleading, and even disingenuous. Indeed one can argue the contrary: the logic of managerial efficiency implies "a thermostat-like system of effective managerial control" which is "strongly linked to a recurring feature of more rational public management" (Norman 2003; Hood and Lodge 2006:175).

The thermostat control system is in turn predicated on a production (as opposed to "procedural", "craft" or "coping") model of public service (Wilson 1989; Gregory 1995a, 1995c, 1999b, 2007a). The lynchpin of this production model is the distinction between outputs and outcomes. Outputs, defined as the goods and services that departments "produce", are by definition tangible, measurable and therefore "manageable" things to which rational rules of calculation could apply. By contrast outcomes,

\footnotetext{
${ }^{26}$ The pay rate for the Secretary to the Treasury for instance had quadrupled during 1982 and 2000 to ten times more than the average wage of ordinary New Zealanders, which, for Greogry (2002), is not a function of either chief executive performance or improved national economic performance'. Pay for performance is perhaps difficult to justify. But such 'inequality' would be perfectly justifiable and indeed necessary from a neoliberal perspective, as rewards for entrepreneurial behaviours, a substantive moral imperative in itself.
} 
the impact of government activities on community and society, lack the objectivity and controllability of outputs. The production model is concerned primarily if not exclusively with the outputs, rather than outcomes. It may be that many of the tasks of the public service do not fit with the image of production so that many outcomes could easily "fall between the cracks", as a number of evaluations have pointed out (Schick 1996:73). But the problem with NPM is that it turns Wilson's insight upside down: while Wilson intended to highlight the incommensurability of the production model and the reality of public service, the NPM theorists simply take this to mean that the reality must be made compatible with the imperative of production. It creates a strong incentive for public managers to ignore the inherent limitation of the production model and to treat all public organisations as if they were, first and foremost, production organisations. The pursuit of clarity and order creates a demand for everincreasing measurability and calculability of outputs as a basis for performance measurement and means of control - the "output fixation" as it was called - that conversely reinforces the mechanistic metaphor of production as if it were the real thing.

Unsurprisingly NPM generated its own distinctive "culture of compliance". As the SSC (1999:27) observes, "the use of small output classes, tight specification and activity measures forced managers to move into a narrow compliance and conformance mode that can discourage innovation and responsiveness". Any illusion of freedom quickly evaporates in the face of a tightly controlled, orderly and rational construction of political reality as manageable tasks.

It also means that the public service has become increasingly distant from the "friendly neighbourhood bureaucracy" and the intimate personal relations between officials/welfare professionals and citizens it traditionally embodied in New Zealand. NPM transformed officials themselves into human resources, citizens into one-dimensional consumers, and reified 
their relations into part of a mechanical process of production of things (Gregory 2007a). The reified production model keeps the people at arms' length from "interfering" with what is supposedly their own creation.

Critics are usually quick to point out that a production model does not fit easily with the peculiar tasks of the public service, especially in cases such as provision of policy advice. As Schick (2001:15) argues, policy advice is not simply "goods and services", but "judgment expertise and professionalism of the chief executive and other senior managers". To treat them as goods or services poses the risk of goal displacement, for what can be readily measured is not always what matters most.

But again "what matters" is where the issue becomes problematic. This is best illustrated if one looks at "the commodification of public service activities which were required to fit neatly into quantifiable pigeonholes" (Kelsey 1993:61, Italics added) for it reveals another meaning of "outputs", namely, as commodities that can be bought and sold on an open market. Scott (2001:172) has made this quite clear himself. Outputs not only "clarify the production functions" but also "facilitate arrangements for internal markets, contracting out and benchmarking". Rather than simply treating the public service as if it constitutes a production organisation, the point is to actually transform it into a series of private businesses which are by definition production organisations.

All of these lead ultimately to the issue of bureaucratic power and control. It is a simple fact, yet one often conveniently ignored by reformers, that despite the NPM rhetoric against the "command and control" hierarchy of the old public service, management is by definition about control and necessarily implies a hierarchical relationship between the managers and the managed. As Gregory (2000) puts it: 
Saying that it is better managed is rhetorically more appealing than saying it is better controlled, and rhetorically more appealing than saying it is more bureaucratic.

The rise of managers necessarily requires "the diminution of other models of power" (Clarke et al 1994:25). But this does not necessarily mean the weakening of bureaucratic power as such. The advent of managerialism was accompanied by a not-so-subtle purge of senior public servants who did not conform to the new ideology and the instalment of reformers, such as Roderick Deane, at key positions of the public service (Mascarenhas 2003:130). The changes also resulted in the SSC losing its centralised power over personnel. In other important aspects there were fewer changes. Treasury, for example, still wielded impressive power, which was probably enhanced, rather than diminished, by reforms which were partly "Treasury driven" (Boston et al 1996; Easton 1997; Kelsey 1995; Goldfinch 1997, 2000).

Beyond the centre, professionals felt the pressure too, especially those in the "helping professions" which were strongly associated with the professional bureaucracy and the welfare state, such as teachers, doctors, nurses, psychologists and social workers. Perhaps the most dramatic example of challenges to the welfare-professional regime of power was the practice of appointing non-health practitioners to executive positions in the health services, although this met with considerable resistance. An attempt to proscribe the decision-making power of professionals and simultaneously extend those of managers by the National Government ultimately faltered in the face of strong opposition (Ashton 1999; Easton 1997, 1999; Belgrave 2004).

This partly reflected the changing demand for expertise. In the old public service, the claims of professionals to power were grounded, as argued earlier, in their knowledge of how the multiple objectives of the welfare 
state could be achieved. Managers by contrast are "the people who know about organisational efficiency and performance" (Clarke et al. 1994:25). Such knowledge becomes indispensable as the systems of performance management and accompanying financial control/audit grow more complex, rational and sophisticated, given the imperative of efficiency that overrides other possible objectives of the state in the NPM discourse. And this simultaneously expands the relative autonomy of managers, so long as they behave like managers, or rational self-interested individuals, as assumed by managerialism.

But contrary to what some critics may appear to suggest, the problem is not simply a conflict between different types of expertise, or between "specialist" and "generic" managers in Easton's terms. If that is the case, then all that is needed in such cases is simply the right mix of different kinds of managerial expertise, given clear objectives, as Scott (2001) argues in reply.

Rather, what really makes the managerial knowledge-power nexus distinctive from the professional one - and also makes it more "bureaucratic" in Weberian terms - is its underpinning by a reinvention of the politics/administration dichotomy, couched in terms such as outcomes and outputs, or purchasers/providers. Unlike the latter, managerial knowledge is explicitly divorced from the substantive social purposes so that it can be applied across sectoral boundaries. What counts as good management is to be defined by management itself without the necessity to refer constantly back to the legitimacy of substantive goals. By contrast the professionals of the welfare state, as argued above, inevitably put themselves in a more "exposed" position. As the managerial realm becomes more and more closed, the autonomy of managerial power increases proportionally and its internal logic harder to detect. As Gregory (2007a:241) observes, managerialism generates 
a surfeit of quantitative technical knowledge, much of it created primarily for the purpose of managerial control as an end in itself [that] grows almost exponentially, unleavened by any comparable development of political wisdom and judgment.

This is a perfect recipe for "goal displacement" because it asks one to pretend that the tasks of management can be conceived as though they involve no need for substantive judgements about trade-offs between conflicting ends. Standards of good management or efficiency are substituted for good judgement and democratic legitimacy.

Such pretence to power can be sustained only as long as the costs are deemed politically acceptable (Gregory 2001: 241-242). But the problem is precisely that within a neoliberal order these costs are acceptable. It is the hegemony of neoliberal values, which itself staves off political contests for legitimacy, that sustains the myth of managerial neutrality.

Perhaps the most worrying consequence of the rise of managerial power is its implications for the balance of power between citizens and bureaucracy. NPM represents a default on the delicate bargain between professional control and citizenship rights in the Welfare State. As Pollitt (1993) notes, citizenship is an awkward concept for NPM. Rather managerialism, like neoliberalism, promises empowerment in the form of "consumer responsiveness" (Gregory 2000; Petrie 1998; Petrie and Webber 2001). Yet, as Kelsey (1993:333) puts it:

When already powerless individuals put their bargaining power against corporations whose raison d'etre is maximising profit (whether they are state or private owned), claims of consumer sovereignty become equally fatuous. 
The NPM discourse suffers from the fallacy of "false customerisation", as Gregory (2003c) calls it, that disguises the inherent imbalance of power between bureaucracy and citizens, and between citizens themselves. As highlighted by the parliamentary inquiry into the conduct of IRD in 1999, consumer sovereignty provides little protection for citizens' rights when they are confronted with powerful bureaucracy (Gregory 2001; 2002a). It is more likely to invite cynicism, rather than build confidence in the public sector, particularly when the "culture of fear and punishment" imposed on tax payers had been accompanied by cool indifference over tax loopholes for the corporate elite.

To put it in another way, managerialism is a strongly technocratic form of power. This is unsurprising given the technocratic nature of its theoretical underpinnings in the "economics of politics". The rise of managerial power is made possible by the revived separation between politics and administration - and in this sense it is more "bureaucratised" - but it is also firmly grounded in the neoliberal political philosophy.

\section{Contracts and Competition}

Another stream of NPM is the structural reform carried out during the late 1980 s and early 1990s. The reforms were extensive and regarded by some international commentators as "a kind of extreme case" (Christensen and Laegreid 2001, 2004). The radical nature of structural changes is partly a reflection of its theoretical foundation in economic theories, especially Public Choice theory.

For reformers, the problem with the old public service with its unified and hierarchical structure is not only that organisations lack clear and consistent objectives, but also, because of such ambiguity and uncertainty, it encourages "provider capture" by self-interested bureaucratic organisations (Boston et al 1996; Treasury 1987). Both contribute to the 
rigidity and inefficiency of the bureaucracy as a whole. The solution was to replace the hierarchical model of command and control with a market model of competition and contract. To achieve this, fundamental changes were made to the sectoral design of the public service. These changes included, as a first step, a series of separations to break up the shapeless conglomerates along the lines of different functions e.g. commercial and non-commercial, between funding, purchasing and provision of services, and between policy and operation functions ${ }^{27}$ (Boston et al 1996; Boston and Eichbam 2005; Scott 2001). These separations would, according to the reformers, allow organisations to be more focused - thus reinforcing managerial reforms - and reduce the risk of "capture"28. Furthermore it would enable and encourage competition between specialised agencies and in turn facilitate "reallocation of functions for focus, synergy and information" (Scott 2001:86).

The structural reforms of the 1980s had something in common with what had gone before. They both reflected a strongly instrumental or mechanical view of the task of institutional design, as if "governmental systems are analogous to a Lego construction that can be disassembled and rebuilt in new configurations with little or no concern for living reality or organisational symbolism and culture" (Gregory and Hicks 1999:5; Gregory 1999, 2001). And this could be seen in the particular language and metaphors used to justify the changes. For instance, Scott (2001:91) sees them as an exercise in "reworking" the old "machinery of government toolkit" and "not so much a novelty in itself".

\footnotetext{
${ }^{27}$ One example of structural changes could be found in the 1993 reform of the health sector. The Department of Health was separated into a policy ministry, regional health authorities funded by the department, and 'Crown Health Enterprises' i.e. public hospitals selling services to the health authority on a competitive basis with private providers. Significant changes were subsequently made to the 1993 system within a relatively short period of time (Howden-Chapman and Ashton 2000; Ashton 2002) Other examples include the disaggregation of the Departments of Scientific and Industrial Research and Transport (Goldfinch 1998a; Norman 2003).

28 "Capture" in this context means that certain interests, mostly from within the organisation, dominate the decision making process and therefore conceal the potential adverse consequences of existing policies. One example is the so-called "provider capture" referring specifically to the operational interests within the departments which subvert the policy process (Boston et al 1996:73).
} 
But as Boston et al (1996:71) argue, the issue of institutional design ultimately was about "values and their relative importance". The explanation of the organisational trajectory was not to be found in the sudden discovery of new design principles, but in the shift of values underpinning them. Just as the ad hoc growth of the sectoral model reflected the ambiguous, conflicting and layered values and meanings of "welfare", the rational or rationalistic appearance of the functional model was a reflection of the priority of transparency, competitiveness and ultimately efficiency. Even by these standards, the evidence seems to suggest that the tendency to use the blunt weapon of structural reforms to solve substantive problems generates more costs. It had gradually become accepted that the preoccupation with clarity enhancement had resulted in excessive fragmentation and therefore the lack of coordination and collaboration (Boston et al 1996; Boston and Eichbaum 2005; Scott 2001).

So structural reforms had not only not necessarily made the public service more economic, it could be argued that the new design had actually been made more "bureaucratic" than before. The problem is that the objectives of the structural reforms were by and large instrumental, at least as the reformers understood them. It ignores the fact that institutional design inevitably reflects the trade-offs between competing substantive values that it must make. And if such trade-offs are a "mess" of contradictory, uncertain and overlapping political judgements, then their institutionalised form must necessarily reflect such "messiness". Here then is a danger of "goal displacement" as the desire for more rational functional forms distract from the substantive pursuit of organisational purposes.

But such cases of "goal displacement" must be understood in their ideological context. Separation of commercial and non-commercial functions, for instance, often drives those commercial organisations to focus overwhelmingly on profit signals even when they are supposed to take other considerations into account (Christensen and Laegreid 2001). But this is fully consistent with a privatisation agenda of which such 
separation is simply an intermediate step. Also there are more complex linkages at work. Take, for instance, the complaint of "excessive fragmentation", which all too often collapses into a meaningless truism, especially in official documents, that "fragmentation can make alignment difficult". Scott was absolutely right to reject such vague criticism (Scott 2001: 86-90). The crucial point is that what counts as coordination or the lack of it, or what is to be considered good institutional design, is grounded in the neo-liberal ideology and sustained by the theoretical faith in the "invisible hand" of the market. For reformers such as Scott, a "fragmented" state is necessary to achieve "coordination through contractual and managerial relationships between the autonomous organisations" (Scott 2001:87). The choice was not between coordination and fragmentation as such, but different forms of coordination (Considine and Lewis 2003; Pollitt and Bouckaert 2004). And this choice of forms ultimately can only be made by political judgements.

The structural changes also accentuate the commodification of public services by using the metaphors of contract and competition. The rhetoric of competition promises choice. But in reality market competition all too readily reduced choices to what could be carried by the tangible "goods and services", or outputs, from alternative providers and ranked in varied prices for comparison - in other words, commodification - often with scant regard for quality, as has been noted by observers of New Zealand's health sector reforms (Howden-Chapman and Ashton 2000). This is exacerbated by the implicit drive towards greater "competitive neutrality" between the public and the private sector as the public sector is forced to compete with the private sector on the latter's own terms in the efficient and profitable provision of commodities, rather than say the ability to uphold the liberal ideal of impartiality between citizens. Some commentators see in this an inherent bias against public providers (Newberry and Pallot 2003). Rather than offering more choices, points out Clarke (2004:35), price competition often serves to: 
drive out or subordinate 'ambiguous' issues of values, orientations and other political choice-making criteria in favour of the rational, transparent and readily calculable 'bottom line'. That which cannot be financially represented (economically valorised) is ruled inappropriate or irrelevant.

The market may very well provide a wide range of high quality goods. And in this way it is superficially similar to a vibrant political realm. The concept of the "marketplace of ideas", which often lies behind the advocacy for greater contestability for policy advice, is one example. But as Lukes (2004) warns, the metaphoric "market of ideas" does not follow from the literal market, which simply does not recognise the intrinsic values of freedom of ideas for the sake of citizenship and social justice. In New Zealand it has been noted that while the split between policy and operation, and the outsourcing of policy advice, might have produced more flexibility and contestability, attention is focused too often on the cost of policy advice sometimes to the detriment of its quality, especially in terms of impartiality, as readily admitted by senior officials (Boston et al 1996:140).

Similarly, the language of the contract reconstructs the relationships between organisations and people around the metaphors of production and exchange, as providers or producers versus funders, purchasers, and owners. This in turn reinforces the competitive relationship between "providers". It limits the possibility of relationships to the exchanges of commodity at arms' length that can be quantified, measured and "contracted for" in the formal legalistic language of commercial law.

Contractualism is not simply a question of "wearing different hats", which may be necessary from time to time. Rather it at least implicitly transforms citizens into consumers and truncates their democratic right to control institutions they created, substituting for that right the freedom to purchase goods and services on a marketplace from the others (Shaw 1999; 
Gregory 2001). The result is that the relationship of trust between citizens and their political and bureaucratic trustees is replaced by the fragmented web of distrust among competing self-interests.

Unsurprisingly this has generated demand for even more precise measurement of outputs as a basis for both competition and contracts. The enthusiasm for measurement is clearly reflected in "the several years of effort in statistical analysis and modelling" that went into "developing standard product and service definitions with associated benchmarked prices, which were used in the annual contracts between the HFA and CHEs" (Scott 2001:182). Scott's comment is all the more interesting given the widespread perception of the failures of the system of contracting for health services, not least because of high transaction costs in specifying the contract (Boston et al 1996; Ashton 1999; Gauld 2001). For some, the pursuit of greater calculability can sometimes be counter-productive as it encourages providers to "skimp on those aspects [of services] least visible to purchasers" (Fougere 1995:115).

For some, this model is unsatisfactory because it ignores the truth that "inherently governmental functions", such as the provision of policy advice, impose certain limits on the use of contract and competition as means of delivery. But focusing on "functions" might be misleading because, as Boston (1995) points out, even the most basic functions of the state can, in theory, be contracted out.

The real problem is that organisational relations and conflicts between public entities cannot be subjected to the discipline of competition and contract because ordering these relations and resolving these conflicts require making political judgements about the trade-offs among values. Conversely those aspects of organisational relations which can be efficiently and transparently managed by the market are not necessarily what is most important. There is a case of "goal displacement" that can be made. But one should be aware that such goal displacement is not merely incidental but implicit in the neo-liberal ideological underpinning. The idea 
is not so much that public organisations could do better under the competitive pressure, but rather that competitive pressure should dictate the organisational form.

Finally, despite NPM's general aversion to politics, the theory of "capture" which provides a crucial justification for structural reforms puts the spotlight back on the issues of power and legitmacy.

Unlike the hierarchical bureaucracy of the past, which derives its legitimacy from the political process, the market model of institutional design seeks to construct legitimacy on the basis of technocratic economic theories independent of the formal political process. Competition and contract, according to such theories, provide an automated system of checks and balances. Autonomous, functionally divided organisations competing for power, in theory, would provide better leverages for political principals, as consumers, to assert control through contracts.

This clearly echoes the "separation-of-power" theory. And it is useful to recall Neustadt (1990:32)'s definition of the American styled separation-ofpower as one of "separated institutions sharing power". It seems that the reformers have stopped exactly where they should have started. The obsession with alleged "capture" of the old public service has driven the reformers to a complex and costly system of separations but the "solution" says very little - at least not explicitly - about power. The technocratic theories that it relies upon do not provide normative standards against which one can verify the legitimacy of control through contracts by "consumers" of various kinds, or the competing claims to power themselves. Neither do they supply any justification for the values that shape the standards and structures of competition and contracts.

Structural reform thus ran the risks of exacerbating the problems they were supposed to resolve. As Boston et al (1996:94) put it: 
Of course, various forms of 'capture' can occur in a bureaucratic context: ideological capture, client capture, provider capture, regulatory capture, and capture by professionals and technical experts. The case for separating policy advice from operation attempts to address only one of these - provider capture.

A fixation with "issues of provider capture or with seeing functional separation as automatic remedy" ignores the potentially greater danger of other forms of capture that arise "[not] because of inclusive organisational arrangements and the supposed problem of internal vested interests but because of the power of external vested interests" (ibid.).

It is not surprising that the reforms have not entirely eliminated the supposed symptoms of capture from inside the bureaucracy. The separation of policy and operations, and separation of funding, purchasing and provision, did pose a serious challenge to the monopoly over policy advice, for example, in the transport sector. But the functional divide generated clearer boundaries of organisational "turf" and thus implicitly strengthened the monopoly of agencies over their own turf (Norman 2003:166). Moreover, the emphasis on functional differences not only obscures the overlapping organisational turfs, it also ignores the possibility of capture by already powerful agencies of smaller functionally separated agencies in the grey zone. Treasury, for instance, has benefited not only from the functional separations which virtually exclude other departments from provision of economic policy advice - which arguably extends to everything done by Government - but also from the removal of some institutional rivals such as the Ministry of Works and the New Zealand Planning Council, ostensibly to improve contestability (Boston et al 1996; Goldfinch 1998a, 1998b, 2000, 2004). This is enhanced by movement of senior ex-Treasury officials to other public agencies as well as influential private organisations such as the NZBR, which contributed to a high level of consistency of views across the public and private sector. The dominance of Treasury might be taken to suggest that structural reforms had exchanged the appearance of capture for the substance of capture. 
Conceivably, however, the most worrying risk comes from the outside. The entrenched bias of the market model against the public sector could well be argued as a form of "capture" by the private sector. Health sector reform in the early 1990s provides one example (Howden-Chapman and Ashton 2000). Public hospitals starved of cash found themselves in a predictable dilemma, as Leys (2001) observes, when they were faced with a well-established private sector with access to capital while the public purposes these public hospitals served were simply not recognised in market terms. Such public purposes included obligations to share information, to provide training and to provide costly and intensive care back-ups for private providers (Howden-Chapman and Ashton 2000). The so-called "consultant capture" was another example (Kelsey 1995; Campbell 1999; Goldfinch 2000). The reformers were peculiarly indifferent to the potential risks of contracting out to private consultants often with a strong and consistent neoliberal view whose very self-interest, according to Public Choice theory, would mean that they were unlikely to recommend a return to public provision, whether or not the latter would actually provide better public service. The use of consultants to advise on structural reforms was susceptible to such risky outcomes (Kelsey 1995).

None of this necessarily proves corruption or conspiracy. The disadvantage of the automated configuration of power and control under the market model is rather that because of its tendency to become an end in itself it could, at best, externalise the conflicts previously hidden and at worst, as Helen Mercer (1995:177) puts it, sustain "the economic and political position of those who can control the competition". Moreover, it lacks the ability of the hierarchical model to escalate them up to political debates and thus ensure the democratic legitimacy of the exercise of power shared between organisations.

Consequently the techniques of competition and control proved just as prone to the unintended or reverse effects as the managerial instruments of reform. Structural reform had set out to tackle the perceived problem of 
bureaucratic capture, but it ended up creating new problems on top of the old.

\section{Reviving the Economic Constitution}

Managerialism and structural reforms are probably the most discussed parts of the NPM reforms. But the revival of the "economic constitution" the Reserve Bank Act 1989 and the Fiscal Responsibility Act 1994 - is undoubtedly the most successful and enduring. The former institutionalises the independence of the Reserve Bank and limits its objectives to control of inflation. The latter imposes a formal framework for fiscal policy with an emphasis on transparency, especially in terms of departure from the "Principles of Responsible Fiscal Management" specified in the Act. These two pieces of legislation bear unmistakable resemblance to the two pillars of the old economic constitution: sound money and balanced budget (McKinnon 2003). The intention of the reform, as Ruth Richardson once put it, was explicitly to place certain policies "beyond the reach of an unfavourable shift in the political winds" (Richardson 1995 quoted in Newberry 2002:8-9). Rather, monetary and fiscal policy should be managed on the basis of "sound" economic theories insulated from political interference (Eichbaum 1999). Clearly then the criteria of "soundness" are not only economic or scientific but ideological.

Constitutions are inevitably about fundamental value judgements. But the new economic constitution was presented, deliberately, with strong emphasis on its instrumentality. The instrumental orientation was embedded in the design of the Acts; for instance, in the distinction between goal and instrumental autonomy of the Reserve Bank (Gregory 1996; Singleton et al 2006). Similarly, the architects of the Fiscal Responsibility Act intentionally avoided substantive definition of good fiscal policy and opted for decision-making principles. And it is reflected in the 
principal goals of low inflation and fiscal management, which as Boston, St John and Stephens (1996) point out,

are, of course, not simply ends in themselves. Rather they are primarily means: their ultimate purpose is to enhance the welfare of New Zealand citizens through improvements in the country's economic performance.

The economic constitution therefore serves to entrench the ends-means dichotomy which runs through the NPM reforms in other forms: between politics/management, policy/operation and so on. And because of its "constitutional" status, it makes explicit the priority of instrumental consideration that is often implicitly assumed in these dichotomies: that the instrumental goals must be treated as overriding ends in themselves. Hence it is not only necessary to remove references to full employment, production and trade, but also references to the substantive purposes of economic and social welfare. Again it raises the question of "goal displacement" and its political implications.

But instrumental decisions inevitably entail moral and political choices between conflicting substantive ends themselves (Gregory 1996). This is more so when the monetarist faith is not universally accepted amongst economists themselves in New Zealand and elsewhere, both then and now (Dalziel 1993; Gould 2006). And even if one were to accept the proposition that monetary policies are incapable of delivering goals other than inflation avoidance in the long run, there remain important political trade-offs to make. For instance, the implicit assumption that short-term sacrifice is necessary for long-term economic prosperity entails consideration of issues such as trade-offs between economic prosperity and other values such as fairness, dignity, temporary or permanent ends; the proper balance between short-term pains and long-term gains; unequal distribution of short-term pains which tend to fall harshly on the more vulnerable poorer section of the society, whereas the benefits accrue mostly to the better off. Neither does the "natural" limit of monetary and 
fiscal policies absolve policy makers from the responsibility to make sure that other policies do deliver the overall goals of economic and social welfare and that monetary policies do not impose unreasonable and unnecessary constraints on these alternative means.

A second issue with the economic constitution is the reified, "supposedly apolitical", notion of economy that lies at its centre. The economy, which "might otherwise be seen as a complex web of economic and social and political relations", becomes a "thing-in-itself" from which the authority of the economic constitution is derived (Gregory 1996:19-20). "The most insidious example" of such a tendency to reify "the economy", according to Gregory, "is probably the powerful euphemism 'financial markets', which in real political terms actually means people/organisations with money to invest, or - arguably - 'rich people'” (op.cit::20). But in monetarist economic terms, financial markets are treated as if they are autonomous entities capable of automatic, "rational" and self-correcting reactions if left on their own. And therefore politics is by definition not only futile but counterproductive. The consequence, as Kelsey (2003:159-160) observes, is that policy making centred around the reified "financial markets" becomes itself "reified as an objective science", while the discourses of "rational expectation", "sound monetary policy", "fiscal discipline" and "economical fundamentals" imply both neutrality and virtue. This intricate construct is at once separated from politics, and paradoxically "intrinsically in the public interest", against which, Kelsey comments, "alternatives were a conceptual impossibility".

What is lost in translation here is the opportunity for legitimate political debates between the people themselves to define what the public interest is and how to achieve it, which they would have been entitled to in a political realm. Moreover, it severs the relations between the public and their political institutions (or the people who run those institutions such as the Reserve Bank governor or the finance ministers), and inevitably weakens the ability of the former to exercise control over the latter. The need to talk to citizens and gain their consent is replaced by the metaphor 
of "talking" to the financial markets and responding to their anxiety or disappointment. The Reserve Bank Governor, for instance, admitted that there were manifest failures to explain to the citizenry the rationale behind the remarkable reforms of the 1980s and 1990s to convince citizens of the merits of those reforms, although he himself nonetheless is convinced that they were meritorious (Brash 1996). To explain to the citizenry as a whole, when citizens of course are divided into classes and other groups by conflicting interests, is of course much harder than simply asserting an economic orthodoxy which happens to coincide in an agreeable way with the interests of one particular section of the citizenry.

And this brings one to the third issue: that of power and legitimacy. Such issues are seldom, if ever talked about, in the technocratic discourses that underpin the revival of economic constitutionalism. They are buried deep beneath the discourse of a politics/economics dichotomy. The need to legislate for Reserve Bank independence and fiscal responsibility nevertheless betrays a basic fact that there is no force of nature policing the boundary between politics and economics. The "insulation" of economics and politics from one another necessarily requires exercise of political power to check the perceived illegitimate use of power. Indeed, despite the official rhetoric of consensus, the making of the economic constitution clearly reflected the dominant patterns of power (Goldfinch 2000).

As Dr Brash's comment above demonstrates, consistent with the discourse of NPM, the legitimacy of power under the economic constitution is based on the "correctness" of economic theories rather than the persuasiveness of political justifications. One might thus describe it as "technocratic", that is, a form of governmental power based on technical expertise prioritised over political arguments. This is essentially a reversal of what happened under the first Labour Government which sought to assert the primacy of politics over technical expertise. 
Technocratic power is power nonetheless. And it has important implications for the configuration of power in society generally. Mulgan (1997b:317) for example regards the "insulation" of monetary and fiscal policies as a deliberate effort by governments themselves to "limit their own power to respond to economic interests opposed to those represented by investors in financial markets". The technocrats are inevitably involved in the game of political power. As Watson (2002, 2003:290-291) observes, central bank independence provides "not only an institutional guarantor of orthodox monetary policies, but also a political guarantor that the interests of a particular sector of society will be inscribed at the heart of the policy making process".

The problem then is that the covert technocratic politics may not have a high degree of political legitimacy outside its own realm. Indeed, the economic constitution necessarily implies a choice between economic expertise and democratic accountability. As Gregory (1996:11-12) puts it, commenting on the Reserve Bank Act:

We can have an Act which really does emphasize the democratic accountability for the Reserve Bank, or we can have one which is set up to ensure inflation avoidance; but we cannot have both.

The Fiscal Responsibility Act poses a similarly difficult trade-off between "the rights of elected representatives, even if motivated by short term consideration ... and the need to ensure continuity and stability in the wider public interest" (Boston et al 1996:288).

In this light, the reformers' argument for constitutional checks on "preoccupation with the short run, either by opportunistic politicians or by the society at large" (Bryant 1996 quoted in Gregory 1996:22) becomes highly problematic. This would not change even if one indeed were to accept the correctness of neoclassical economics. This is not only "paternalistic". It is also highly bureaucratic in a sense that it entrenches in 
the constitutional rules the triumph of technocratic reason over political values.

While the NPM reform purported to "banish bureaucracy", it achieved precisely the opposite: by committing the reform to the pursuit of instrumental efficiency, and by dismantling the welfare professionalism that had previously served to "problematise" such a pursuit, it simply accelerated the process of "bureaucratisation" in a Weberian sense and, in doing so, amplified the political irrationalities of a supposedly "rational" bureaucracy. As Gregory (2003c) argues, NPM has largely replaced one form of bureaucratic control with another. And moreover it has unleashed the bureaucracy from its internal political constraints. But what happened to the constitutional system?

\subsection{From Westminster to Where?}

Before examining the constitutional implications of the 1980s and 90s reform, a few words must be said about the changes in the electoral system. For some commentators the introduction of MMP represents a departure from the Westminster norms of strong majoritarian government. But it is equally possible to argue that the introduction of MMP helped to bring New Zealand's system closer to an era before the domination of the two-party system - an era with fairer representation values and a higher degree of democratic legitimacy - where these basic norms first evolved (Palmer and Palmer 2004: 17). Hence it is not surprising that some commentators have concluded that MMP does not appear to change the role and function of the public sector (Boston et al 1999; James 1997).

It is interesting to note that the introduction of MMP has been regarded as a reaction against the 1980 s/90s reforms, and the "Blitzkrieg" politics under which the reforms were implemented (Boston et al 1996; Denemark 2001). One might therefore ask, if MMP has strengthened the Westminster system, did the NPM reforms weaken it? 


\section{Sovereignty under Siege}

The NPM reforms in New Zealand did not set out to challenge the doctrine of parliamentary sovereignty, or at least not explicitly. Treasury's 1987 briefing Government Management, for instance, begins with a conventional account of parliamentary sovereignty but proceeds quickly to a strikingly different convention with a heavy tint of Agency Theory, asserting that:

the Government is the agent not of Parliament but of the electorate, responsible to the electorate which alone determines its fate. When voters go to the polls they are conscious of choosing a constituency representative, but the most important question before them is which party shall be the next government (Treasury 1987:53).

Officials concluded therefore that all that was required was the "effectiveness of translation of the preferences of voters into outcomes, and efficiency in the conduct of government administration" (1987:54). There is however little explanation of how else one could determine and refine the meaning of "electoral preferences" outside a representative parliamentary democracy. This is perhaps not surprising given that as Jonathan Boston observes, " the advocates of the reforms have generally wanted to reduce the importance of, if not de-legitimise, preferences that are expressed through the political arena" (Boston 1992 quoted in Kelsey 1995:297). And moreover, this means that the NPM model is orientated by design, as Jacob et al (2007:16) argues, towards the needs of the executive rather than Parliament. The inconsistency of the reformers' formal endorsement and practical rejection of the doctrine at the same time lends itself to the accusation of "constitutional illiteracy" by some commentators (Hood 1990:15).

The threat to parliamentary sovereignty is evident. For a start, the economic constitution further reduces the scope for Parliament to exercise 
its legislative supremacy, limited as it has always been. Although the Acts posed no de jure constraints, the intent was clearly to achieve de facto entrenchments of principles of monetary and fiscal policies, which effectively bound future governments (Kelsey 1995: 233-234). Challenges to parliament's supremacy were not all as obvious as this. The replacement of the traditional "command and control model" with competition and contract also had serious implications for parliament's legislative power. As Taggart (2004:618) argues, the substitution of traditional regulation with a "fictitious legal person's power to contract" is implicitly a transformation, in his words, "from 'Parliamentary Powers' to privatisation" 29 . This further weakens Parliament's control over regulation.

Parliamentary control over finance raises a slightly more complex issue, not the least because strengthening such control is one of the chief objectives of the NPM reforms. Yet while there have undoubtedly been notable improvements, the actual overall performance of the new financial system has been questioned by a number of commentators (Ellwood and Newberry 2007; Newberry and Pallot 2004; Newberry 2003; Boston et al 1996). The reformers appear to have taken for granted that the benefits of the new public finance regime - more transparency and tighter control of public expenditure - would automatically translate into better parliamentary control of supply (Scott 2001; Treasury 1996). However, as McLean (2005) argues, the perspectives of the "financial markets", the ministers and parliament are not necessarily the same: what might be an increase of "transparency" for one might be a drastic reduction for another.

Indeed the celebrated techniques of private sector accounting do not lend themselves easily to parliamentary scrutiny, and often seem more likely to generate "information overload" than better scrutiny (Norman 2003). The size and specification of "output classes" for example has always been a

\footnotetext{
${ }^{29}$ Some may argue that the law of contracts places greater control on government via the common law courts. However although the courts have been active in certain areas of common law rights, such as certain human rights and Maori customary rights, their record for controlling the more mundane but no less significant aspects of executive and bureaucratic powers is disappointingly poor (McLean 2006).
} 
problem for parliamentary scrutiny (Boston et al 1996; Scott 2001; Schick 2001). It is predictably difficult to fit parliament's eclectic concerns into neatly defined categories. Even the introduction of accrual accounting, which has generally been viewed as a success, does not necessarily serve parliamentary scrutiny well because of the inherent difficulty in translating "notional book entries" into departmental activities that require parliamentary approval (Aiken 1994; Boston et al 1996; Newberry 2002; Newberry and Pallot 2006). It is not difficult to see why this did not pose a problem for reformers, who at any rate would probably prefer market provision, but did pose a problem for politicians.

Nor does the new financial system necessarily enlarge the scope of parliamentary financial control. Certain activities of the government, such as its operation on the financial derivatives market, remain the preserve of the executive. Moreover, while input controls were removed from parliament on the basis that such controls are redundant in an output based system, the controls were in fact transferred to Treasury, rather than simply abolished. This aroused some concerns about the balance of power between the executive and parliament, as well as the rationale for removing input control in the first place (Newberry and Pallot 2006).

These are not merely, as Scott (2001:56) seems to believe, "technical issues". These issues matter firstly because they enhance or erode parliament's control over finance, and secondly because they affect the ability of Parliament to exercise control over the actions of the Executive. The paradox is that the new regime might give Parliament better financial control but it might also remove its leverage of power. The former is a matter for technical debate but the latter means that political principles are at stake. As Laing (2006) puts it, "the elevation of constitutionally irrelevant concepts" that focus on "accounting" rather than accountability, has "the potential to undermine decades of negotiation and settlement between the executive and the Senate". 
An even starker warning could be found in the Clerk of the Senate of Australia's comment that a similar financial system, introduced in Australia since 1997, has enhanced executive power in "reversing the results of the English Civil War, the Revolution of 1688 and the reforms of William Pitt the Younger" (Evans 2007). Comments like this are meant to shock. However, at the very least, claims that the NPM public finance system enhanced parliamentary control must be viewed skeptically.

This leaves the third and most important role of Parliament - scrutiny of the Executive. Reformers can easily point to testimonies by senior officials that suggest significant improvements as a result of the reform (Scott 2001:63-67). But critics could just as easily find evidence that shows otherwise. Gregory and Painter (2003:67), for example:

Members of parliament often feel that their scrutiny of agencies is inevitably perfunctory, and that the "real issues" lay obfuscated beneath the professional façade presented by officials.

They also quote one New Zealand select committee chairperson who described departmental chief executives as "master of the bland fudge". Another claimed that the committee was deliberately lied to by departmental officials. A senior MP also recalled that one of the agency heads appeared more concerned about missing an afternoon appointment than appearing before the committee for a financial review (ibid.).

Politicians' misgivings were reciprocated by reservations from officials, especially about opposition members. One official reportedly claimed that "there was insufficient control on opposition members who waste the time of the executives" (Norman and Stace 1997 quoted in Scott 2001:108). Another described the select committee environment as "harsh and illogical" (Norman 2003:156).

The relationship between parliamentarians and officials is of course always going to be an uneasy one, as it is between democracy and 
bureaucracy. Under the old system, they had been held together by constitutional norms and mutual respect, if not trust. The NPM reforms, however, had put additional pressure on this.

There were warning signals that parliamentarians and officials had become much less trusting and more combative. In 1998, the Chairman of the Fire Service Commission - a management expert with private sector background - was reported as telling a select committee that "he had better things to do than answering their full frank and pointless questions" (Sunday News, 18 May 1998). Old-fashioned bureaucrats might have shown more respect for constitutional subtleties in such circumstances.

Of course, dramatic controversies such as these are rare. Yet low visibility does not necessarily mean less damage. The use of commercial confidentiality, for instance, is a common strategy that has serious implications. And this issue is clearly related to the NPM reforms and to contractualism in particular.

In a sense, NPM has reversed the trajectory towards greater openness in the pre-1984 era that resulted in the Official Information Act. Certain information such as the pay and conditions of senior officials, which previously had been publicly available - and arguably should still be - was now removed from public and parliamentary scrutiny on the ground of commercial confidentiality ${ }^{30}$. This may seem immaterial for reformers. But the ability of such information to generate public controversies, for instance in the cases of "golden handshakes" in the 1990s, often suggests otherwise. An investigation by the Auditor-General into severance payments concluded that while "confidentiality has its place ... it can also be at the cost of transparency" and went on to note that for many "secrecy

\footnotetext{
${ }^{30}$ A notable example occurred in the aftermath of the Fire Service Commission fiasco when the new Chairwoman, citing confidential clauses, refused to give to a select committee the details of severance payments for outgoing senior staff. Another concerns the Chief Executive for Work and Income who refused to divulge to a select committee details of an out-of-court settlement. These cases prompted Sir Geoffrey Palmer to suggest that parliament could threaten to use its power to imprison if officials refused to comply (Dominion Post, 12 April 2000).
} 
is evidence of public officials having something to hide" (Auditor-General 2002:14).

This issue has generated much debate in other Westminster countries, particularly Australia (Barrett 2001; Cameron 2004; de Maria 2001; Evans 2002; Freiberg 1999; Roberts 2000, 2001). As one Australian commentator points out, the issue of commercial confidentiality and openness is not just about commercial information but rather is about "two distinctive visions of governance" (de Maria 2001:93). Moreover, commercial confidentiality has provided "the traditional inclination of government to secrecy with ... a powerful additional weapon in the age of contracting out", especially in cases of bureaucratic failure (Zifcak 2001:89).

A different but not entirely dissimilar issue in this regard is the separation between commercial and non-commercial entities, which resulted in, for quite some time, severe limits to parliament's power of scrutiny for the former. Air New Zealand, for instance, was only brought under parliamentary scrutiny in 2002 after the collapse of Ansett and subsequent bailout with public funds. Even then, scrutiny is limited for the fear that this might put Air New Zealand "at a commercial disadvantage to its competitors" (Cullen 2003). Indeed there has long been a perceptible unwillingness for SOEs and privatised companies to cooperate with parliamentary scrutiny (Boston 1992:578; Gregory and Painter 2003).

Putting these together a different picture than what the reformers had promised emerges. The NPM styled public finance system, as constructed under the Public Finance Act 1989, has undoubtedly important benefits. But, at the same time, such improvement was bought at the high cost of fundamentally undermining the constitutional sovereignty of parliament. Indeed, the embedded barriers to effective scrutiny would appear to have reinvented the "culture of secrecy" rather than diminishing it. 


\section{Unaccountable and Irresponsible}

Turning to the issue of accountability and responsibility reveals the same conflicted views of reformers concerning constitutional conventions. Palmer and Palmer (2004:91) contend that the NPM reforms have not altered the doctrine but only made accountability and responsibility more transparent. This position, interestingly, does not appear to be strongly endorsed by the reformers themselves. Government Management argued that the doctrine was obviously outdated: it was "designed a century ago for a small public sector with limited functions, where ministers took all decisions of any importance". Worse still:

[the] current system creates confusion as to managerial responsibility which in turn seems to reduce accountability ... Responsibility for administration goes constitutionally to the Minister; legally to Minister and SSC together; practically it tends to disappear (Treasury 1987:59).

Thus while in theory ministerial responsibility is still the beginning and the end, in practice the reforms are not so much about strengthening the doctrine as it is about searching for ways to implement a new accountability without running into obvious constitutional difficulties. Responding to Palmer and Palmer's comment quoted above, Scott argues:

While the doctrine of ministerial responsibility may not have been eroded in respect of ultimate accountability, the situation today is different in a practical sense. Chief executives are now much more accountable for the delivery by their department of specified services, and they can face severance or non-renewal of contract on performance grounds alone (2001:126). 
Here in a nutshell is the managerial formula of accountability. For Scott, clearly, the emphasis in the discussion of "clarification" falls on the changes, rather than the continuities. But just how different is managerial accountability from ministerial responsibility?

The first difference is that whereas ministerial responsibility begins with constitutional roles of ministers and officials, managerial accountability starts from the question of "what". Managerial accountability relies absolutely on the distinction between inputs, outputs and outcomes, which is absent from the doctrine of ministerial responsibility, for it a key task is to clarify the managers' accountability and to assess their performance (Schick 1996, 2001; Scott 2001). Outputs, as Schick (1996:1) puts it, are "the lynchpin of the New Zealand accountability regime".

The choice of output is based on perceived objectivity - and thus measurability - and controllability. The rationale is simple: "for accountability to operate effectively, the individuals held accountable must have control over their results" (Boston et al 1996:264). This puts the managerial notion of accountability firmly on "the logical-positivist foundations" of "the hard rationalist school" (Gregory 2003a:564). Outcomes, by contrast, lack both. Scott (2001:175-176) argues that accountability for outcomes is likely to fail because outcomes can only be partially controlled by individual chief executives; the causal relationships between outputs and outcomes are frequently not well understood; timeframes for outcomes are usually too long; and many outcomes are simply too difficult to measure. From a managerial perspective, apparently, "if you can't measure it you can't manage it" and by implication, you cannot be held accountable for it either.

Such obsession with measurable and controllable results - here accountability is understood as synonymous with control - has been criticised by several commentators (Gregory 1995; 1998; 2003a; Scott 1996, 2001; Stone 1995). Schick (1996:74), for example, puts the case subtly that outputs were chosen because "they provided a reliable basis 
for managerial accountability, not because they are the most important indicator for government performance".

The paradox is that the clarity and simplicity of managerial accountability for outputs limit its use in reality, for it is inherently difficult to establish a causal relationship between the "production" of outputs and the ultimate outcomes that matter in an inherently complex, uncertain and politically charged environment, not to mention that not all bureaucratic actions can be reduced to reified notions of production in the first place (Mulgan 2004). "Just about the only certainty" in the Cave Creek case, Gregory (1998a:524) contends, was "that the platform was an output that produced a precise outcome: 14 dead and four injured". Scott (2001: 136-142) argues that managerial accountability should have made it easier to dissect the overall accountability for the tragedy into small parcels of failure along the managerial chains of command. Indeed, it is clear enough where responsibility for the production and the purchase of the outputs lie. But this simply begs the question: if evidence is as sufficient as Scott believes it is, why then were no individuals prosecuted for criminal negligence given the senseless loss of lives at Cave Creek? All the official and academic efforts that had gone into clarifying accountability and responsibility, including Scott's own, would have been superfluous. Scott undermines his own case in fact, perhaps unwittingly, by suggesting that the "Crown" should be prosecuted for the tragedy at Cave Creek. Why indeed should one ever resort to the ambiguous and often confusing concept of the "Crown" if responsibility can be devolved to individual managers and employees who "produced" specific outputs that led to the tragic outcome?

But the limit of managerial accountability is not just its impracticality. Managerial accountability is intrinsically limited because by definition it fails to capture what is arguably the most important facet of bureaucratic acts, that is, the inherent public and political nature of such acts: the unavoidable judgment of values, the inevitable exercise of discretionary 
and non-discretionary powers, and the positions of trust held by officials and politicians for such powers.

In the case of Cave Creek, it would be futile to look for a precise causal relation between factors such as an organisational culture of "doing more with less", or the lack of funding, with the collapse of the viewing platform at Cave Creek. There is none. All one could conclude from evidence is that these factors played a part in the final outcome. But this does not absolve anybody from political responsibility in terms of whether their acts and judgments, as well as the outcomes, in themselves were consistent and seen to be so - with public expectations for officials. Such responsibility is even more important when specification of outputs or the causal relations linking outputs and outcomes, are lacking, as often is the case with the "craft" - and more so with "coping" - rather than the "production" tasks of the public service.

The public of course do not always see accountability as a function of good management, and neither do they always find managerial accountability in this narrow sense satisfactory. As Mulgan observes:

Interested parties, whether ministers, members of parliamentary committees, media or members of the public rarely, if ever, resort to output statements or outputs measures as a basis for holding government to account (2004:9).

What this illustrates is a gap between managerial accountability and public expectation, and between managerial assumptions and political reality. The reified notion of a production process is unlikely to be convincing for the public who actually bear the impacts of bureaucratic power. Cases such as Cave Creek provide vivid illustration of the virtual irrelevance, and impotence, of the outputs/outcomes dichotomy in satisfying public demand for political responsibility (Gregory 1998a). 
Secondly, managerial accountability also differs from ministerial responsibility in terms of its process (the "how" of accountability). Consistent with its rationalistic orientation, the process of managerial accountability takes the form of "counting", rather than "probing" (Gregory 2003a:565). More formally, the focus is on matching ex-post measurement of performance against ex-ante specification of targets - in other words, verification of achievements against predetermined goals and indicators rather than open-ended discussion and debate as in the case of ministerial responsibility.

The problem is that the emphasis on "verification" ignores the fact that expost measurement of "performance", just as the ex-ante specification of objectives, is inherently a "subjective and value-laden activity" which is why performance measurement is "popular in theory but difficult in practice" (Thomas 2007). And just as objectives are inevitably multiple, vague and potentially conflicting, the measures of success or failure also are open to different and possibly contradictory interpretations. Accordingly "performance is what the people most directly involved have in mind when they use them" (op.cit..:417). The "performance" of the Department of Conservation in the case of Cave Creek is unsurprisingly intensely focused on the specific failure to ensure public safety, rather than any predetermined financial or performance targets. This would require an interactive process to construct the standards of good performance in specific contexts, according to Thomas, rather than assuming "there is an objective reality 'out there', just waiting to be discovered" (ibid.).

Yet the discourse of accountability as verification tends to foreclose discussion of their meaning and relevance to a particular perspective of "performance". This in turn reinforces the focus on outputs, rather than outcomes, because the outcomes are prone to descending into "a debate about evidence, causality and degree of control" (Scott 2001:175). Critical reflection, or "double loop" learning, is explicitly discouraged. 
Managerial accountability is thus heavily "rationalised" in the typology devised by Weber, as Stone (1995:514) argues. It is "increasingly regularized or systemized and governed by 'instrumental' or process values" and therefore increasingly "professionalised". Unsurprisingly, such a process puts a heavy premium on the formal techniques of financial accounting and auditing, which is evident in the so-called "audit explosion" in the public sector (Power 1994; 2003). This can be seen in the growing volume and sophistication of budgeting and reporting documents such as corporate plans, estimates, purchase and performance agreements, annual reports, SOls and others in New Zealand's public sector as a result of NPM reform (Boston et al 1996). Yet, as this happens, the unintended or perverse effects of enhanced accountability also become evident. This is reflected in the perception that "a lot of reporting and accountability in the budget cycle has become a game" (Norman 2002:623). Accountability becomes, in Michael Power's words, "rituals of verification". And rather than spurring performance it simply generates a checklist mentality (Schick 1996). As Gregory (2003a) comments, an over-commitment to performance measurement can actually subvert accountability.

Critics are familiar with such paradoxes of "performance" (van Thiel and Leeuw 2002). They can be understood in Weberian terms as a case of bureaucratic "goal displacement": performance measurement becomes more about "measurement", as an end in itself, than performance. As it happens, accountability becomes increasingly internalised as a part of managerial control - and therefore more opaque and closed - instead of connecting externally to politicians and the people who ought to have the final say on the assessment of bureaucratic performance beyond its narrow managerial definition (Matti 2007). The outcome appears to be increased bureaucratisation, rather than enhanced democratic and political accountability.

Such risks are clearly present in the case of Cave Creek. An SSC performance review prior to the tragedy found that William Mansfield, the Chief Executive, was doing a good job, particularly in improving the 
department's system of financial management. Another review after the tragedy found no ground for seeking his dismissal. It is not difficult to draw a parallel between this situation and that of the Chief Executive of the UK prison service, Derek Lewis, in 1996. Lewis contested his dismissal on the grounds that, among other things, he had met all his performance targets (Polidano 1999; Woodhouse 2005). Had the Chief Executive of DoC shared Derek Lewis's tenacity, he might have argued for a bonus instead. Fortunately this was not the case in the Cave Creek tragedy. Yet this was by no means a foregone conclusion.

Another consequence of the concept of accountability as verification is that it further obfuscates the relationship between responsibility and accountability. In Cave Creek, it has been argued that the Chief Executive and the Ministers involved were "accountable but not responsible" (Gregory 1998a). Accountability, Gregory argues, has been fulfilled by ministers' explanation to parliament and two inquires into the tragedy. But it is not clear that their moral and ethical responsibility after the event has been met in the face of public demand for explanation and retribution for what should or could have happened.

It is true that traditional ministerial responsibility can be reduced by prevarication to mere answerability, but it can also be stretched to inflict serious political damage through effective probing by the politician. The point of giving an account is to confirm that ministers are politically responsible. By contrast, the new form of accountability is deliberately distanced from political responsibility through the employment of a policy/operation divide. And in doing so it enacts a distinction between objective responsibility and subjective responsibility (Mosher 1968; Gregory 2003a) which arguably did not exist under traditional ministerial responsibility. The "objectivity" of managerial accountability allows clearer boundaries to be drawn on matters that managers can be held accountable for. This forces the accountability component of ministerial responsibility to stand on its own. If Ministers are no longer responsible for the acts of their subordinate, then accountability can be nothing more than 
recounting the "facts" or telling the "truth", with no political or moral or ethical implications on the Ministers' part. Conversely, the political dimension of administrative acts is obscured when ministers, as politicians, no longer have to offer a political explanation of departmental administration. In other words, there is an important qualitative difference between the requirement to give a "full" account under traditional ministerial responsibility, which means engaging with open-ended political debates and discussion - including what constitutes facts, truth or evidence when conclusive causal linkage is lacking - and the insulated verification of "facts" that managerial accountability demands. Such a difference seems to have escaped some observers, such as Baberis, who believe that managerial accountability simply exacerbates the old problems already there (Baberis 1998). Nonetheless it adds fuel to the criticism of traditional responsibility that it allows politicians and bureaucrats to be "fully accountable but irresponsible" (Gregory 1998a; 2003a).

The problem lies not so much with ministerial responsibility, but in the subtle encroachment on the doctrine by managerial accountability. It could be argued that, far from being "fully" accountable and paradoxically irresponsible, managerial accountability implies a limited account and a limited responsibility. Ministers hence can be managerially accountable but politically unaccountable, and therefore politically not responsible.

In the Cave Creek case, the question of managerial accountability has been satisfied in terms of identifying the causal linkage between various parties' action or inactions and the final tragedy. But it could be argued that the parties involved, politicians in particular, did not accept responsibility to the extent that the convention would have required and therefore failed to give a full account for issues such as integrity, or moral and ethical choices. The alternative to "I am responsible but not to blame" appears to be "I am not operationally responsible, nor politically accountable, hence cannot possibly be blamed". 
This raises a further question about blame and punishment. In theory, managerial accountability, combined with a performance measurement system, provides an automated process for apportioning blame and enforcing punishment, if the causal links between actions and outcomes can be conclusively established. But instant satisfaction is bought by drastically reducing the quality and scope of responsibility. Ministers, being politicians, will often attempt to dissociate themselves from blame, and similarly public servants would try to hang on to their job. The point of ministerial responsibility is to ensure they get away with less by exposing them to public scrutiny and political pressure. Managerial accountability, on the other hand, means that the public and parliamentarians often face a much more difficult, if not impossible, mission of proving the causal link between bureaucratic actions and ultimate failures in cases such as Cave Creek $^{31}$.

The separation and specification of roles, including the roles of officials and politicians, and the focus on verification, is partly designed to make it clearer who is responsible. It makes ministers responsible and accountable for the achievement of outcomes, while the sphere of chief executives is deemed to be the production of departmental outputs towards achieving these outcomes (Treasury 1996; Scott 2001). The notion of control underpins the allocation of accountability and responsibility, though probably more so in the case of chief executives than politicians. In fact, the managerial theory cannot explain why politicians should be held responsible or even accountable for "outcomes", such as economic growth or public welfare, which are almost always beyond their personal control.

\footnotetext{
${ }^{31}$ A more recent case concerns Mrs Folole Muliaga, who was terminally ill and dependent on an oxygen machine. She died less than three hours after the electricity supply was disconnected to her house by a contractor of the state-owned Mercury Energy, due to an outstanding balance. Police investigation concluded there was no evidence to justify any charge against the company, contractor or staff involved. The problem, as in Cave Creek, is that the lack of causal evidence not only absolves the legal culpability of parties involved, it also glosses over the moral and political responsibilities of the staff, the company and ultimately the Government which owns it.
} 
The difficulty with this control-based notion of accountability is that it has very little to say about the "problem of many hands", as in such cases as Cave Creek (Mulgan 2004). Bureaucratic actions very often are collective by definition. They are collective not only because bureaucratic actions inevitably overlap, both within the bureaucracy itself and with the political executive, but also because the political dimension of bureaucratic actions makes it impossible to separate individual decisions from the broader political choices and the exercise of political power. As Gregory (2001) argues:

The attempts to specify role relations according to categories like outcomes and outputs are politically naïve and offer a poor guide to understanding the ambiguities and uncertainties of government relations.

Managerial accountability represents a paradox. On one hand, no one is clearly responsible for the bureaucracy as a whole. This lack of clear responsibility reinforces the perception of bureaucratic organisation, in Hannah Arendt's terms, as "the rule of nobody" (Gregory 1998a; 2003a). This in turn underlies the invention of "systemic failures" as an explanation of the tragedy at Cave Creek, since Judge Noble could find neither any individuals nor any particular group of individuals who were responsible. The Chief Executive and the Minster did not resign directly in response to the tragedy. Blurred responsibility serves to promote a reified notion of "large organisations as abstract entities with a life of their own" and further conceals the "ultimate humanness of profoundly impersonal governmental systems" (Gregory 1998a).

Some commentators have argued that what is needed is simply a heavier dose of managerial accountability (Scott 2001; Hunt 2005). But these commentaries occlude, as much as they seek to explicate, responsibility and accountability. Indeed, while critics dislike the term "systemic failure", there seems to be a parallel and intrinsically contradictory tendency to "fill in the gap" by resorting to such mystifying personifications as "DOC" or 
"the Crown" or even "risk management system" as if they too have a life of their own- a system by another name would be just as impersonal - when the apparent individualistic explanations are exhausted, while refusing to bring their own reasoning to the logical conclusion. If the Chief Executive is to blame, then who is culpable for tolerating the Chief Executive's "poor" management and even poorer political judgement for so long, even after the event, other than the Minister (assuming the SSC had fulfilled their oversight function)? If the DOC or the Crown or systems of any other kind are to blame, then who should be responsible for them? If nobody is to blame, then who is responsible for perpetuating the myth of "the rule of nobody"?

One explanation of its inability to grapple with personal responsibility for collective actions is that managerial accountability, as Mulgan (2004:16) argues, confuses "the question of who was actually in charge and who should therefore take collective responsibility". In other words, the responsibility for maintaining the power-relationship between politicians and public servants, and ultimately the relationship of trust with the people, are attenuated. In this light, the traditional convention provides much more clarity and certainty than managerial accountability, since the responsibility for such collective failures falls prima facie on the politicians.

In the case of Cave Creek, traditional ministerial responsibility would argue for the head of the Minister. One could expect the Minister to argue that he is "responsible but not to blame". Whether such an explanation or excuse is acceptable or not would be subject to political debate and judgement. Managerial accountability, by contrast, automatically shields the Minister from responsibility and blame by invoking the separation between policy and operation ${ }^{32}$. And if one were to accept the logic of such separation, how is it fair to blame the Chief Executive - or even to insist on his statutory responsibility to ensure public safety for using DoC facilities in

\footnotetext{
${ }^{32}$ Indeed, as Graeme Hunt puts it, 'Mansfield need only have reiterated his statutory duty under the State Sector Act for the general conduct of the department' to shield his Minister from a widespread, and for Hunt misguided, call for him to resign (National Business Review 23 August 1996: 48).
} 
the first place - given that "he did not have a hand in the fateful platformbuilding at Cave Creek" and could not be expected to at any rate (Hunt 2005)? This seems more akin to cynicism than "objective" allocation of responsibility.

Thus, in theory, managerial accountability operates alongside the convention of ministerial responsibility. In practice, the former displaces the latter.

\section{Breaking the Bargain}

Not only did NPM replace the informal relational contract between politicians and officials, it also fundamentally altered the relationship between them. In New Zealand and elsewhere, the traditional Schafferian bargain had been intentionally broken down to make way for a new managerial bargain (Savoie 2003; James 2002; Hood and Lodge 2006).

Signs of change are not difficult to identify, partly thanks to the high profile of public servants such as Christine Rankin (James 2002; Gregory 2005a). Arguably New Zealand public servants have never quite been faceless bureaucrats. Yet compared to the old bureaucrats, the new public managers have been remembered more often for their insistence on managerial prerogatives and their contractual rights, than their popularity with the public. Seen in this light, the demise of anonymity is important not so much in itself but rather for what it reveals about the changing nature of power relations between politicians and officials.

The new bargain seems to shift the balance of power towards bureaucrats or managers rather than politicians. As Gregory (2001:250) argues, "whether or not dressed up in the languages of freedom to manage, empowering operators and managers implies a consequential disempowerment of the political executive". The NPM reforms have given managers an independent source of power in managerial or economic 
expertise, rather than in democratic mandate. Whereas the latter makes it clear that politicians, because they are elected, should retain the ultimate control over the bargain, the former places officials in direct competition with their political principals. Indeed the loss of anonymity could be regarded as a tacit acceptance of the independence of officials from the Minister. Research confirms that officials during the NPM reforms were less tolerant of politics and more guarded against "interference" by politicians (Gregory 1995b:172-173; 2004b).

Politicians naturally do not welcome such competition for their authority. The expansion of managerial discretion was met by Ministers hungering for more control over bureaucracy, especially after major failures such as Cave Creek (Gregory and Norman 2003; Maor 1999; Norman 2003). In theory, the reforms would enhance the control of politicians as "principals". However, as Scott (2001:109) acknowledges, this role requires "different skills, different from those used in political management" and "ministers with such skills are very rare". To take advantage of the efficient control system provided by the NPM reforms, ministers must first learn to behave as the reformers expect and accept the managerial terms of the game, if not becoming managers themselves. The assertion of managerial control thus does not necessarily compensate for the loss of political power and the political instinct of ministers often drive them towards more direct control.

Of course, this has not prevented politicians from insisting on the old forms of control, which manifests itself in, for example, "the obsession with inputs" over issues such as the money spent on consultants, severance pay or information technology (Norman 2003:86-93). But these ad hoc attempts to rein in managerial freedom tend to entail little more than tinkering at the margin, rather than any fundamental rethinking about the managerial philosophy of freedom and control. Some commentators argue that this leads to "learned vulnerability" that saps the innovative energy of managers (Gregory 1995a; Norman 2003). An alternative argument might be that unconstrained managerial freedom is to blame for undermining the 
trust between politicians and officials in the first place. Moreover, the operation of the managerial bargain is based on the separation between politics and management. This opens up new opportunities for "cheating" between ministers and bureaucrats over what is inherently a grey zone rather than two separate worlds, as a number of commentators have observed (Hood 2001; Hood and Lodge 2006; Savoie 2003). This makes it more difficult to trace the ebbs and flows of political power between bureaucrats and politicians when both can disguise the exercise of power simply by breaching the boundary or pushing it outwards.

But, perhaps more importantly, the managerial bargain implies a change in the nature and purpose of the "bargain". Whereas the traditional bargain sought to subjugate bureaucracy to politics, the managerial bargain legitimises the competition for power between politicians and officials, and therefore acknowledges that the latter have an independent claim to power based on managerial or economic expertise rather than democratic credentials. The traditional bargain aims at affirming democratic control of power, while the managerial bargain tries to ensure the efficiency and effectiveness of management by insulating them from political intervention. The traditional bargain is hierarchical: it trades power and independence for trust and protection. The managerial bargain resembles a market with separated parties exchanging powers.

It is no longer clear who is or should be in charge, but it would seem that the bureaucrats would naturally have an edge over politicians in the pursuit of efficiency and effectiveness. One commentator remarks that "during the reform years, the conventional relationship between elected government and bureaucratic advisors in a Westminster system was to a great extent reversed" (Nagel 1998:243). The bureaucracy, rather than the politicians, became the initiator of policies. It is not surprising, therefore, that some have feared values such as political neutrality and loyalty might give away under contractual demands and competitive pressure. 
Consider, for instance, political neutrality. The new system of fixed term contractual relations that put an end to the symbolically important "permanence" of employment inevitably arouses worries about political patronage (Boston et al 1991; 1996). Such fears were found to be exaggerated (Boston et al 1996; Scott 2001). One should not overlook that the contractual devices attempted to provide some safeguards: for instance, the five-year term, which is specifically designed to counter the political "business cycle" (Scott 2001). At any rate, even under the old system permanence was not meant to be an unconditional guarantee of job security. For some, the new arrangements simply acknowledge officially what was long the implicit requirement: that public servants have to be responsive to their ministers, though often this implies a redefinition of responsiveness in "customer-oriented", rather than political terms.

However, the reforms may have "politicised" the public service more subtly than by means of politically risky patronage (Gregory 2004a). New Zealand reforms raised questions about "policy-related" and "managerial" politicisation. According to Mulgan (1998), policy related politicisation refers to "appointing people with well known commitment to particular policy directions that may render them unacceptable to a future alternative government" while managerial politicisation is where the Government replaces the incumbent with new appointees in order to exert its control over the departments. It is not difficult to identify either form of politicisation during the reform years. A notable individual example is the appointment of a well-known advocate of the NPM reforms to the position of State Service Commissioner in the 1980s to replace the incumbent who had criticised the reforms (Gregory 2004a). Another concerns the Treasury, found to have adopted inconsistent methodology when asked by the National Government in 1993 to cost the Labour Opposition's policy (Mascarenhas 2003:131). Concerns about these new forms of politicisation underlined the Labour government's reservations about the capacity and willingness of public servants to implement its policies when it came to power in 1999. 
It could be argued that the dichotomy between politics and management has facilitated both forms of "politicisation" by confusing political neutrality with political antipathy. As a result, it has put too much emphasis on the negative sense of political neutrality (the protection of the merit principle from external threats) and overlooked its positive meaning (the ability of public servants to serve any democratically elected government). This also implies that the cause of politicisation is not to be found in conspiracy theories but rather in the structural entrenchment of neoliberal values and policy preferences through apparently "apolitical" means, such as the NPM reforms themselves. In other words, pressures of politicisation come from the changes within the public service. The merit principle remains intact from external threats, but the concept of merit itself has been extensively reconfigured according to a new set of administrative and political imperatives. This is manifest for instance in the preferences for those candidates with economic or managerial expertise and Treasury backgrounds for top positions in New Zealand public service since the reforms (Boston 2001).

The difference between new and old forms of politicisation, like the boundary between politics and management, is not fixed. Gregory (2004a) argues that policy related politicisation in New Zealand tends to reflect partisan preferences. Boston (2001) finds that public managers in the mid 1990s were more likely to vote for the National party and were significantly to the right of most other "opinion leaders" and the community as a whole. The conservative tendency of bureaucrats is not entirely surprising. Nonetheless it is telling that two officials and advocates of the NPM reforms later became high-profile politicians on the right, after moving on from their high offices ${ }^{33}$.

It casts serious doubt on the likelihood that the reforms have actually reduced the risk of partisan bias, or whether they have simply assumed away the problem, and more importantly whether the

\footnotetext{
${ }^{33}$ Dr Brash, the Reserve Bank Governor, became the National Party leader from 2003 to 2006. Graeme Scott, Secretary to the Treasury, was on the Act Party list.
} 
politics/administration separation has in fact made bureaucratic politics less transparent and open, and thus more susceptible to partisan biases when left on their own. Indeed it may be politics itself, rather than management, which needs to be defended against the perils of new forms of politicisation, especially given the increased autonomy and power of officials under the managerial reforms.

A related issue here is the advent of political advisors (Eichbaum and Shaw 2003; 2005a; 2006; 2007a; 2007b; 2008b). The rise of political advisors could perhaps be conceptualised as a response to the demand for additional capacity and capability required to preserve "popular control and constitutionally independent, non-partisan and expert public or civil service" and not solely as a response to the NPM reforms in New Zealand. But such a demand is surely not because of the old regime of "public administration" emphasising only "the routine administration of procedures and rules" or that policymaking under the old welfare state was any simpler than making monetary policy along neoclassical lines. It is not difficult however to envisage an alternative explanation that echoes the analysis above - that the politics/management distinction, which attempts to "depoliticise" the public service, has generated an increase in partisan politics. Adding a third, or fourth, element into the bilateral relations between ministers and officials would not necessarily help to address the fundamental tension between bureaucrats and politicians. It might simply shift the issues to elsewhere and invent new forms of "politicisation" (Eichbaum and Shaw suggest a new administrative politicisation on top of Mulgan's typology). While ministerial advisors might help to take some political heat off officials, by attempting to insulate officials from such problems and giving them an easy way out, it risks displacing the notion of "political neutrality" with a toxic combination of partisan politics and (supposedly) apolitical management.

The other side of the coin, loyalty, is similarly under stress. At any rate, the NPM reformers are suspicious of the degree of loyalty of bureaucrats to politicians found in the old public service. Loyalty of such a type runs 
counter to their faith in the public choice discourse of organisational selfinterests. Thus the NPM reforms, and contractualism in particular, imply a very different kind of loyalty, one based on the sanctity of contract - and "privatised" loyalty between agents and principals - rather than the democratic legitimacy of political authority. Yet, as Hay (2004) argues, an assumption of self-interest has a propensity to become a self-fulfilling prophecy. It can easily dissipate the trust between officials and politicians, which is crucial to sustain the loyalty bargain between them. At best, the managerial bargain reduces loyalty to what can be specified in the contract; at worst, it provides a powerful incentive for each party to exploit the opportunities of cheating and blame shifting provided by the new bargain. This latter outcome in turn will reduce trust even further.

Leaking is one indicator of the degree of loyalty of public managers towards their political masters. Although there is no evidence that leaking has become more prevalent than previously in New Zealand, it may have changed in character (James 2002:29-30) and become more "malevolent". Public servants who are active political party members may now be more willing to leak information when they believe there is something "wrong" when their concept of wrong is a belief that it is contrary to "their party's principles or policies". Such "surreptitious" leaking is underlined, as James argues, by a distorted view of the public interest that "transcends the loyalty to a minister" and may go directly to specific users or services or to employers (ibid.). Leaking is not solely a result of managers flexing their muscle. It might be a last resort for disenchanted officials who find that "the formal advice process has become anything but free, frank and fearless" under the NPM reforms (Morrison 1998).

The provision of "free and frank" advice is itself an important component of loyalty. The convention has not been forgotten by the reformers. Scott (2001:80) for instance has stressed the importance of the convention and insists that the convention should be included in the Chief Executives' performance agreements. But it is difficult to see how exactly one could specify such performance. After all, the convention is about the 
constitutional norms of interaction between officials and politicians. It is not simply the "quality" dimension of an output, which could be easily measured and "produced". There is little evidence suggesting that contractual instruments have made public servants any more fearless and forthcoming with advice.

Quite the contrary, concerns have been expressed about the possibility that the convention of free and frank advice might actually be undermined by the new bargain (Boston et al 1996; Gregory 2005a). It might be true that the distance between politicians and officials would reduce direct political pressures. Yet, the paradox is that, especially given the culture of openness engendered by the OIA, that:

In a politically charged environment where risks and blame games become more apparent, where chief executives are less anonymous players in the political arena, it is much safer for them to align themselves with the stances and interests of their ministers, the better to ensure public support from ministers when things go wrong (Gregory 2005a:22).

The desire for contestability has the potential to exacerbate such risk aversions, as a wish to retain a lucrative contract might compel advisors to fashion their advice according to the preferences of potential buyers (Boston et al 1996:138).

This again illustrates the differences between the traditional bargain and the managerial one. Whereas the former allows politicians to exert their control over the bureaucracy - and thus gives them the freedom to reject advice - it ensures that advice will be listened to, if not acted on, and that politicians will get away with less as a result. The managerial bargain shows that attempts to reduce the degree of legitimate political control might open many other doors through which political influence can advance itself, and can be exercised with fewer conditions attached. 
There is also a risk that the convention of free and frank advice, like whistle-blowing, might become a politically-loaded term with distorted meaning. The "speaking truth to power" formula, coupled with the policy/management divide, can easily end up in a deadlock between managerial "truth" and political power. There is, and has always been "a fine line between giving free and frank advice and obstructing the government's policies" (Clark 2000 quoted in Scott 2001:355). And politicians often understand, thanks to instincts acquired and honed in their climb to office, this dialectic between truth and power better than managers or bureaucrats. This is not to argue against the convention of free and frank advice, but simply to point out that the managerial bargain misunderstands the nature of the convention.

Thus, at first glance, the managerial bargain promised political neutrality and loyalty as well as political control of bureaucratic power. The truth seems to be that the replacement of the traditional bargain by the new managerial bargain may have done more to sabotage these constitutionally important values than to preserve them.

The NPM reforms in New Zealand were intended to "reinvent Government", to make it more "business-like": more efficient, more effective and more economic. However, paradoxically, but not surprisingly, it has reinvented a Weberian bureaucracy in managerialist garb. What it has managed to banish is the political and constitutional constraints, already eroded by the neoliberal hegemony, on bureaucratic power. 


\section{Are We There Yet?}

\section{$\underline{7.1 \text { March left, or right }}$}

The election of a Labour-led Government in 1999 signalled, according to the Labour Prime Minister, an end to fifteen years of neoliberalism. However the official death of neoliberalism does not come with a resurrection of the ideas of the old Welfare State. In New Zealand, as in the UK and Germany, those ideas have been set-aside for the so-called Third Way or the "new social democracy" (Clark 2002; Maharey 2001, 2003; Chatterjee et al 1999).

A precise definition of the Third Way is probably more elusive than the first or second: it can be "everything found between those poles of economic and social organisation" (Chatterjee et al 1999:35). And New Zealand's third way is probably bolder than its British or American versions. Nevertheless, the New Zealand model demonstrates something which is central to the Third Way idea, that is, the belief that the fundamental values of these two previous models - social justice, economic growth, and more recently environmental sustainability - could be and probably somehow seamlessly combined, without the conflicts and the necessity to choose.

But a political vision without conflicts resonates better with an anti-political philosophy than the ideals of the left, which inevitably challenge rather than embrace inequality. Even if the Labour party has glossed over the conspicuousness of economic growth with new communitarian slogans such as innovation, inclusion, social cohesion, knowledge society, sustainability and many others, economic growth emphatically remains the explicit priority, if only because maintaining the confidence of business is a necessary evil for the new social democrats. For instance, in her speech to Parliament, the Prime Minister argues: 
Indeed for most of us the development of a stronger economy is a means to an end. That end is higher living standards and the ability to provide a better quality of life for all our people. An inclusive and cohesive society is an essential building block for a growing and innovative economy (Clark 2002).

Arguments such as this, however incoherent, help to highlight the continuity in the changes. The quote above leaves an impression that, for Third Way champions, social justice itself is just a means to an end, secondary to the needs of the economy, which in turn serves some higher purpose. This is why it is necessary to reformulate the old left ideals into friendlier communitarian concepts such as social capital or human capital so that they can fit more easily into a framework of the knowledge economy. "Higher living standards" and "better quality of life", therefore, are to be understood as economic dividends rather than as the achievement of ideals of social justice. The driving purpose appears to be to make it possible to distribute these gains in a fairer manner in order to ensure more growth and thus prosperity. It means taking more seriously the trickle-down theory of wealth creation and thus avoiding a direct confrontation with the neo-liberal values hierarchy of economic growth over social justice.

There is another similarity, related to the above, between the politics of the Third Way and neoliberalism in New Zealand. As Colin James (2001) argues, Third Way politics is also "technocratic": "it is concerned with "what works', not 'what should be'". In other words, it is concerned with the positive, rather than the normative. "What works" is the new mantra of legitimation, especially in social policy areas. Effectiveness, rather than economic efficiency, is now the imperative for policy makers. The problem, however, is that these two approaches have the same risk of "goal displacement", even if the things displaced may be quite different from each other. Effectiveness, just like efficiency, is likely to become an end in itself. The pursuit or rhetoric of things such as innovation or knowledge economy (read IT) often make them look suspiciously like a technological 
fix for social and political problems. This will be discussed further in the discussion below in relation to the Managing for Outcome initiatives.

If the values of New Zealand's Third Way politics are similar to those of neoliberalism in important aspects, one might expect that their conceptions of social relations might not be entirely dissimilar either. The civil society or the community is offered as an alternative to the market as a coordinating mechanism for society. As a corollary, "partnership", with its emphasis on trust, norms and reciprocity, takes the place of contract and competition. An implication of these changes is a shift from the consumer model, based on market relationships, to the stakeholder model. The adoption of these communitarian notions can be traced to the previous National Government under Jim Bolger, and many have featured in neoliberal discourse. However, they have undoubtedly gained momentum under an officially social democratic government.

Nevertheless the "real" meaning of these notions in practice remains a contested subject for New Zealand commentators. Take for example "partnership". For some, it is an important means, or at least a promising starting point, to overcome the neoliberal legacy (Walker 2004; Larner and Craig 2005). Other observers are more sceptical (Curtis 2003; Fitzsimons 2000). Curtis (2003:7) claims that the Third Way "promised by Prime Minister Clark and increasingly operationalised by central government, local government and community groups" is best understood "in terms of continuity" with the neoliberalism begun by Labour in 1984 .

The latter claim may be slightly unfair although it does pick up an important point. The convergence of the two discourses is probably not an intentional result but an "unintended" consequence of reified notions of community, as discussed in chapter 2 . To reiterate, just as the market discourse only captures a single dimension of social relations, the communitarian discourse transforms citizens into, in Fitzsimons (2000)' words, "community subjects" under the mythical banner of community, 
while community norms substitute for economic rationality as the basis of calculability and stability.

A further problem, related to the reification, is its neglect of inequality within or between communities, or partners, not only collectively but ultimately between people themselves individually. Nor do catchphrases such as "networking", "relationship-building" and "coordinating", derived from notions of networks and partnerships, always provide an accurate or meaningful description of what actually is going on. Labour's communitarian discourses feature "networks" and "partnership", the "business community" and "public private" partnership, as well as trade unions and other social groups. But partnerships do not in themselves resolve the perennial conflicts between partners and are not necessarily in the interests of everyone. Vehement opposition from the business community over major issues such as the Employment Relations Bill, or more recently electoral finance and climate change, shows just how fragile the harmonious image presented by the Third Way discourse can be.

A final point concerns politics itself. There is certainly a slow-down from the blitzkrieg approach in the previous Labour Government, partly thanks to the MMP environment. Moreover, there is an official acknowledgement of the need to put values back into politics (Maharey 2003). The incremental approach has led to significant changes over the years, for example with the re-nationalisation of ACC, the reform of the Employment Contracts Act, and Working for Families. But the communitarian discourse has a certain anti-political bias of its own, albeit more benign. It poses difficulties because values such as community or social capital - like terms such as democracy and accountability - are almost impossible to object to and in a sense are devoid of political substance. There are thus inherent limitations for purposeful political action and debate. In this regard, notably, the key pieces of legislation, including those underpinning the NPM reforms, have not been fundamentally changed, despite significant changes in the social policy area. 
Along with the new style of politics there is an increasing awareness of the importance of trust, now often dressed in the garb of social capital (Walker 2004). Third Way politics is certainly more "inclusive", compared with the reform years. A shift has occurred away from particularised trust in institutional elites during the 80 s and 90 s to allow more participation by the general public through increasing use of "consultation". It is harder to see, however, what has been done to restore the trust in political institutions depleted by the reforms. The tendency to take for granted that the trust is "organic" and therefore will thrive in the absence of external forces - both markets and the government - is noticeable in the New Zealand discourse, for instance, in Walker's assertion that "trust is largely intuitive, and can only be engendered". There is no conscious effort to make a distinction between "particularised" and "generalised" trust ${ }^{34}$. It precludes a more active attempt to overcome, rather than simply contain, the neoliberal legacy. Moreover, there is a risk that the discourse of trust can obscure the demand for a broader basis of political legitimacy. Without addressing such fundamental problems as socio-economic inequality that generate distrust, the kind of centrism that now dominates New Zealand politics is likely to fall short of expectations, even by its own standards. "Consultation fatigue" can be seen as a result of this failure to actually deliver on its promises.

\subsection{Post-New Public Management}

The new politics has important implications for the Public Sector. It does not mean, however, that the view of bureaucracy under the Third Way is any more positive than it was before. Quite the contrary, debureaucratisation remains central to the Third Way agenda. It is part and parcel of the Third Way, goes the argument, to prevent "an overloaded, bureaucratic state" that is "not only unlikely to provide good public services" but is also "dysfunctional for economic prosperity" and in its

${ }^{34}$ see n.15 above. 
stead to promote "state agencies [that are] transparent, customer oriented and quick on their feet" (Giddens 2003). What makes the new reform different, amongst other things, is that unlike the NPM reforms, as Gregory argues, it does not appeal to any formal theoretical knowledge. Or perhaps more accurately it does not rely on any explicit theoretical alternatives to those underpinning the previous reforms. There is certainly no reference to economic precepts such as rational self-interest and so on, but nor are these fundamental principles ever explicitly challenged. The system, it seems, is fundamentally sound, and what is necessary is simply modifications at the edge, to make it more effective as well as efficient.

\section{Managing for Outcomes}

A key theme of this new strategy is the shifting of focus from output-based management to the so-called "managing for outcomes" or MfO (Cook 2004; Ryan 2004; Advisory Group 2001, 2002; SSC and Treasury 2003). At the risk of oversimplification, MfO can be defined broadly to mean "developing and managing policy and the policy process in a manner that seems most likely to be effective in achieving government's desired goals and objectives" (Ryan 2004:1).

In practice, the changes can be identified as a series of counterpoints with the previous output-based framework (Boston and Eichbaum 2007; Chapman and Duncan 2007; Mallard 2003; SSC 2003). They involve firstly broadening and refining the specification of outcomes, which in theory is a joint exercise between Ministers and chief executives. This evolves, in part, from the Strategic Result Areas/Key Result Areas (SRA/KRA) framework under the previous National government. Now strategic goals are to be framed in terms of a series of high level outcomes (key government goals) and intermediate outcomes on a departmental basis. Second, it means reformulating the respective spheres of management and politics. Not only are chief executives required to manage the production of outputs, they are expected to show how their management of outputs and resources contribute towards government outcomes, even 
though they are not formally responsible for achieving outcomes. And lastly, it leads to a modified performance management system, which attempts to incorporate outcome targets in the circle of ex ante specification and ex post measurement. Critical to this process is the development of Statements of Intent (SOIs), medium-term documents that "provide a succinct, strategically-oriented description and explanation" of departmental plans for achieving and monitoring outcomes, including capability implications (SSC and Treasury 2005:8). These are in addition to requirements for output based forecast information against which the annual reports are assessed. The passing of the Public Finance (State Sector Management) Bill in 2004 formally cements these changes.

The renewed stress on outcomes reflects, amongst other things, a deliberate move away from the singular emphasis on efficiency and economy towards a wider range of values. This is consistent with the socalled "public value" theory, which has gained considerable popularity in New Zealand and elsewhere as an alternative to NPM (Moore 1995). Whereas NPM encourage officials to be more like managers in the private sector, the public values theory by contrast urges them to become "public entrepreneurs" in the business of "creating public value" with a particular emphasis on the distinctiveness that "emerges from within public organisations and networks rather than from outside" (Moore 1995; Ryan 2004:105-106). This bears a striking resemblance to the Third Way rhetoric of social entrepreneurship and "social capital".

The difficulty with this approach, as with the discourse of social capital, is that the emphasis in reality often falls on the "entrepreneurial" rather than the "public". And there is often a strong tendency to ignore potential conflicts between entrepreneurial norms and public values. Consider, for instance, Ryan (2004:106), who appeals to managers to "use their collective imaginations, savvy and courage, manage the risks, bend or workaround the rules, mix n'match resources, and do 'whatever it takes' to be effective - within the limits of cabinet approval and public sector ethics and probity". Clearly there is an inherent contradiction between doing 
whatever it takes and staying within the limits. And rhetoric such as this provides very little guidance on what is to be done to prevent the risk of "goal displacement" when officials are actually faced with a dilemma between the pursuit of instrumental effectiveness towards whatever ends and the choice of substantive ends themselves that prescribes limits of effectiveness. And perhaps more importantly, it risks undermining the distinctive "publicness" of the Public Sector, the peculiar tasks of which are fundamentally political and neither managerial nor entrepreneurial. Such tasks are characterised by values and beliefs held by people themselves, which are not "things" in their own right that can or need to be "created" by entrepreneurs. And these values imply unavoidable conflicts that cannot be simply "risk-managed" away. Rather, the resolution of value-conflicts must be subjected to certain constitutional rules in a democratic polity, which must not be bent or broken by officials for the sake of bureaucratic effectiveness. The pursuit of public interest plainly cannot be privatised as entrepreneurial activities of officials on their own. In other words, the danger of treating officials as "the new platonic guardians of the public interest" is that it is a role for which they are "not appointed, are ill suited, inadequately prepared and more importantly are not protected if things go wrong" (Rhodes and Wanna 2007:406).

Similarly while the shifting focus on outcomes might have lessened the preoccupation with measurable and specifiable outputs - although specification of outputs remains a bottom line - it is far from clear that the shift actually has any impact on the mentality of measurement and specification, or the "commodity fetish" that accompanies it.

What is notable indeed is an increase in measuring, rather than actually managing for, outcomes. The new zeal for measurement can be seen in the development of social indicators and more recently environmental indicators. Clear specification of outcomes is critical for the success of MfO (Cook 2004:12). Clarity of objectives remains the ideal, only that the objectives must now be specified and measured in outcome, rather than output terms. This is to be achieved by ever more sophisticated 
performance indicators, such as benchmarks, to be included in the Statement of Intent (Treasury and SSC 2007). This is hardly a solution to the problem of NPM. Rather it simply glosses over the difficulty of measuring "outcomes", which are by definition unmeasurable, of those organisations that are not the "production" type. The limit of this approach is that it never actually challenges the output/outcome bifurcation. In practice, managing for outcomes often becomes little more than managing outcomes as if they were really outputs. What can be measured, rather than what matters, still dictates what can be managed. So the rhetorical focus on outcomes inevitably has to be scaled back to something measurable such as "impacts" - "results that are directly attributable to the activity of an agency" - rather than outcomes as such (Treasury and SSC 2007; Webber 2004). Craig (2006:207) concludes that the process yields "hairy outputs", that is, "risk managed outputs framed in outcome terms". It is not so much a shift as a roundabout.

The emphasis on measuring outcomes is furthered by the application of intervention logic, which seeks to provide an "evidence-based, systematic and reasoned description of the causal links between outputs and outcomes" (Baehler 2002; 2007; Pathfinder 2003). The problem is that intervention logic belongs to a long line of technocratic "solutions" that "invariably acknowledge aspects of political reality that undermine the integrity of rational techniques, but having done so they proceed to speak and act if there were not really a problem" (Gregory 2003b; 2004b:308). Rather than acknowledging the limit of technocratic solutions, intervention logic simply ignores the fact that politics is not just about complexity and risk, but fundamental conflicts that cannot be managed away by clever techniques. "Stripping complexity down to its essential parts" (Baehler 2002:14) might be easy; the real difficulty is for people to agree on what counts as "essential" and what all this is for in the first place, which are what makes political life at once "messy" and worthwhile.

Finally, there are issues of power and legitimacy. Like its predecessor, $\mathrm{MfO}$ is filled with rhetoric of empowerment. For instance, public agencies 
are urged to get more "citizen and community centred", which, in practical terms, means things such as "moving from Wellington-centred to community-centred”, building "capability for 'subsidiarity' [sic] [including partnership in problem solving]; using enabling technology to simplify things for citizens" (Advisory Group 2002; also Ryan 2004; 2006a).

Such rhetoric, if not reality, appears to be a positive move away from the truncated version of rights in the consumerist model that underlines the previous reform. However, despite its lip service to the concept of citizenship, the emphasis of MfO is clearly on a much more narrower idea of "responsiveness", primarily if not exclusively in an instrumental sense, to certain defined or at least definable substantive values via technological means, as illustrated above.

The problem is that the emphasis on "responsiveness" to citizens often comes with a tendency to avoid issues about political conflicts and power relations. It tends to assume that people can be and want to be rallied in support of some unambiguous long-term outcomes, against which conflicts are simply temporary and irrational. This makes it easier to prescribe a shopping list of what reasonable citizens really want, supposedly, such as one-stop shops and e-government. It is important to be responsive, but the question remains, responsive to whom? MfO has little to say in this regard, except by appealing to the vague ideas of "community" or "partnerships" that glosses over the divides between and within communities. Therefore techniques such as devolution or partnerships, whether or not dressed up in terms of empowerment, may continue to reflect the dominant culture of the 1980s and 1990s where the objective is to govern at a distance, rather than genuine power sharing (Larner and Mayow 2003; Cheyne, O’Brien and Belgrave 2004).

One example of this is the current e-government initiative (Millar 2004; Gauld and Goldfinch 2006). The theory is that e-government is "an out-ofWellington, citizen-first and service-based view of the business of government", the "revolutionary impacts" of which had probably not been 
thought about seriously enough by many of New Zealand's 30000 public servants (Mallard 2002a; 2002b). It offers, supposedly, "a way of facilitating greater participatory and grass-root-type democracy" (Gauld and Goldfinch 2006). However, as Gauld and Goldfinch point out, experience with e-government projects in New Zealand show that "dangerous enthusiasm" for the scheme is often driven by idolisation of politicians and public servants, the myth of the technological fix, commercial incentives and last but not least, managerial fads, rather than the empowerment of citizens. This is not surprising, for e-government is after all, in Gregory (2007a:233)'s words, 'the quintessential expression of rationalisation" and as such is inherently inadequate to addressing issues of political power and citizenship.

What then of the power of politicians? Since 1999 the Labour Government has taken a more "hands-on" approach to public management, much to the dismay of advocates of NPM (Scott 2001). The MfO initiatives could be seen as part of this overall attempt to reassert political control. But exercise of direct control is the exception rather than the norm. Politicians, for their part, were ambivalent towards it. The distinction between steering and rowing is after all as central to the Third Way ideology as it was to the NPM reforms. As Tony Blair and Gerhard Schroeder put it, "the state should not row, but steer: not so much control, as challenge" (Blair and Schroeder 1999).

This fits well with MfO. The truly significant change under MfO is not so much empowering politicians to do more "rowing" as about freeing officials to do more "steering". Indeed, there is a discernable dislike of politics, for example, in the usual complaints about the "adversarial tone of Westminster derived polities" and "the need for rebalancing technical and political rationalities in favour of the former" (Ryan 2004:27). Arguments such as this reflect more of a pre-emptive attempt to head off political intervention than any genuine acceptance of the role of politics. It seems odd because if "technocracy" might be a problem, then arguably it would follow that rebalancing in the opposite direction, i.e. more politics rather 
than more technical rationality, is necessary. This perhaps explains why, as one independent evaluation found, despite the initial enthusiasm, Ministers showed little interest in the actual implementation of the MfO initiative (Economics and Strategy Group 2003). The evaluation on the contrary has "brought the outcome components of this framework significantly 'closer' to departments by involving them more explicitly in the selection of outcomes". Thus rather than empowering politicians, public managers "are being asked to rebel against standard politics and usurp the democratic will of governments" (Rhodes and Wanna 2007:413). It shifts the power balance further towards the bureaucracy.

\section{Managing in Networks}

The competitive order has also come under scrutiny in new waves of reform, as concerns are raised about the apparent "fragmentation" and "siloisation" of the public service. In some cases - for example, the merger of the Department of Work and Income and the Ministry of Social Policy (and later Child Youth and Family) into the Ministry of Social Development - separated agencies are put back together. But the reform has consistently and carefully avoided any suggestion of another wholesale restructuring, warning that structural changes are "not a panacea" and can be "blunt and excessive" (Advisory Group 2002). Reformers instead prefer softer initiatives such as "joined up governance" or a "whole-ofgovernment approach" to address the problem of a fragmented public service (Advisory Group 2002; Boston and Eichbaum 2005; Gregory 2003c, 2005c; SSC 2007c). The means to deliver these initiatives, as the Review of the Centre recommended, are "circuit breaker teams" and "super-networks". The former focuses on vertical integration of policy and operational agencies. It is supposed to "solve previously intractable problems in service delivery by drawing on front-line knowledge and creativity together with central technical support". The latter is meant to work across policy areas by grouping and managing government agencies 
in 7-10 "super-networks", which would "represent a move towards substantial structural change" (Advisory Group 2002).

Despite the lack of any overt appeal to theoretical knowledge, the approach clearly reflects the emerging theories of so-called "network governance", as an alternative to an explicitly market-orientated institutional order (Considine and Lewis 2003; Rhodes 1997, 2007). It hits all the right notes of the fashionable discourse of "networks": interdependency, voluntariness, informality, information sharing, trust, to name but a few.

And central to this new model of governance is often an appeal to "public values", which fits comfortably with the MfO initiative discussed above. Bardach, for instance, defines inter-agency collaboration as "activities by agencies intended to increase public value by having agencies working together rather than separately" (Bardach 1998:17). Yet there is a real difficulty with this instrumental recourse to "public values", as if they were settled ends. It does not make sense to argue that network governance provides "better" means to achieve "public values" unless one can be reasonably certain what these values might be. The theory of network governance often invokes shared values, but what exactly does it mean for agencies to "work together" in the face of conflicting values which set the people themselves apart? Is "working together" still always necessary, desirable and possible without the presumption of consensus? The tendency to speak of "working together" or collaboration in the place of competition, as if they are ends in themselves requiring little more than what Bardach calls "managerial craftsmanship", thus poses the same old problem of goal displacement. As Spicer (2007) argues, it is a peculiar characteristic of the network theory to embrace "the shop-worn politicsadministration dichotomy" while seeking to "transcend" it. It is not surprising that in practice the network type of initiative often puts weak constraints on organisational behaviour but strong constraints on politics, which "begs the question whether constraints on politics in partnership 
form a barrier to organisations changing their behaviours in JUG [joined-up governance] compatible ways" (Davies 2007).

Paradoxically this is why radical change towards a more unified hierarchical structure, as Greogry (2005c) advocates, may be necessary. This is not because a hierarchical structure is any better in delivering certain "public values" than the market or the networks. Conflicts will persist within a hierarchical structure. Because of this, however, it is important, symbolically and politically, to affirm the shared "publicness" of public institutions, despite their potentially conflicting organisational values, and to ensure that such conflicts can be overridden from "above" through the political process when they can or need to be settled.

A second problem concerns the tendency of network governance to reify "networks" as if they are objective things independent of the organisational and individual actors constituting them. To be fair, not all theorists are ignorant of the problem. Rhodes, for instance, warns that "an antifoundational story of governing structures - of markets, hierarchy, and networks - must not hypostatize them; that is, represent them as a concrete reality" (Rhodes 2000). Yet, despite making this significant point, Rhodes himself tends to focus heavily on charting the contours of the network structure, rather than challenging its normative and subjective meanings (see Rhodes 1997; 2007). If a network is not simply what is, then it is important to identify those particular values and beliefs that distinguish the network actors from, and identify them with, say, market players. In other words, an "anti-foundational" view of network governance cannot treat it as merely a neutral, precisely "scientific" analytical tool that can be applied to any values and beliefs. And this in turn will inevitably question the legitimacy of different "stories" that can be told through the interpretive framework of network governance. It means one can no longer talk of network as an alternative to the market or something else without actually challenging the values and beliefs of market itself. But as Hay and Richard (2000) point out, the popularity of network theory is partly driven by the "strategic flexibility and adaptability" of the network concept. 
Predictably, there is little desire for network practitioners and theorists to engage with political debates.

It is not surprising then that network theories often consciously or unconsciously reproduce and reinforce the reified notions of "production" central to the competitive order. Despite the supposed paradigm shifts, network theorists continue to talk in distinctively market terms about dependency on resources, about process of exchange, and about the importance of defining property rights to reward cooperative behaviour (Rhodes 1997, 2007; Milward and Provan 2000). One still ends up where one started, with the superiority of the market in allocating scarce resources through carefully defined property rights.

Finally, as is the case with virtually every Public Sector reform initiative, the network approach talks profusely about empowerment through the possibility of "power sharing" with various networks (Huxham and Vangen 2005; Dovey 2003, Gray 2002, Majumdar 2006). But as practitioners are only too aware, power sharing is:

not an easy concept to put into practice because no one likes to give up power, whether that power is explicit or implicit. Organizations, which are collections of individuals, are probably more resistant than individuals in giving up power. In New Zealand, top down contracting mechanisms have reinforced "power at the top" because the purchase paradigm requires the top to be the place where the decision making occurs about how much and what services to purchase (Dovey 2003:88).

Dovey goes on to quote Judge Mick Brown in the review of Child Youth and Family that "while there may be some enthusiasm to hand over responsibility this is not accompanied by any great desire to hand over control”. 
The problem is that network theories do not appear to offer any realistic alternatives. Dovey for instance urges officials to "learn to share the power that has been the reserve of public organizations for the last 100 years or more, with community groups and their representatives". Leaving aside the accuracy of such a statement given the hollowing out of the Public Sector over the last twenty years, this seems very much a trite answer to a tough problem. For one thing, it says nothing about the imbalance of power between different communities and their representatives, as well as amongst public agencies. The simplistic yet popular notion of selfenacting, or self-organising, networks tends to obscure how the game of power is played out on the ground according to the rules and relations hardwired by previous reforms, given that power will always be distributed unequally. The notion ignores the uncomfortable truth that managing collaborative networks may often require, in Huxham and Vagen's terms, "collective thuggery" with leaders willing to actively shape networks through manipulating agendas and playing politics. This has important implications for practices of network governance. For instance, it highlights the potential of the "leadership" emphasis to reinforce the already powerful position of central agencies such as the Treasury, rather than facilitate power-sharing with smaller and less powerful ones. And above all it eschews the genuine empowerment that is necessary to enable less powerful agencies to participate meaningfully in different networks.

There is a greater danger in the tendency of network governance to overlook issues of inequality of power, because it glosses over the "dark side" of networks that can not only undermine the legitimacy of networks themselves, but can also damage democratic governance (Greenway, Salter and Hart 2007; Klijn and Skelcher 2007; Lowndes 2001; O'Toole and Meier 2004; Papadopoulos 2007). After all, the origin of network analysis can be traced back to the insights of so-called "iron-triangles" or "triple alliances". All of these stories in the past suggest, like markets, networks might be structured to privilege those already powerful, while giving an appearance of openness and transparency. 
Implicit in all this is another apparent case of "goal displacement": instead of strengthening democratic governance, "network governance" becomes its replacement. Quite often, as O'Toole and Meier (2004) argue, such justification simply "re-enacts a network version of the venerable politicsadministration dichotomy". According to them, the bulk of literature frequently relies on "instrumental logic" to explain network patterns, "typically with an emphasis on clients or clientele needs" and overlooking "important political issues about what networks do, how they perform and how they can be directed towards goal achievement". But a more political interpretation is not without its problems. Ryan (2006b:44) argues, for instance:

Formally, public servants participate in these policy networks as delegates of the Minister, but the very character of the network relationships, the internal interdependence of the members and the exploratory nature of the work, means that, to be effective, public servants cannot simply enact that role. They cannot act in removed or distant or controlling ways, preserving the pristine elements of their role as "public servants".

But surely the author does not mean to say that the public have no alternative but to accept potentially corrupt practices of public servants, which serve the private interests of closed private networks rather than the public, simply because of working in policy networks. The possibility that network relationships may conflict with the role of public servants as delegates of democratically elected government might simply mean that it may not be appropriate for public servants to engage in such networks.

As Hansen (2005) argues, democratic governance would entail querying criteria for inclusion in networks, as well as "ensuring an 'all' embracing and 'other' regarding inclusiveness, constitutive to a democratic 'community of difference'". Network governance, at least as it is currently presented and practiced, seems determined to escape such a challenge. 
Therefore, it is necessary to heed the advice of Etizioni-Harvey, which bears a remarkable similarity to Helen Mercer's observation:

Network governance process may well privilege the more powerful interests by providing access for them, so that by the very process of empowering some, network governance may well disempower others (2005:114-115).

\section{Managing the Constitution}

Of the two pillars of the economic constitution, the Reserve Bank Act came under pressure from the appreciation of the New Zealand dollar in 2007 but there was evident resistance by the major parties to significant change and the Fiscal Responsibility Act was absorbed into the new Public Finance Act. There has been no retreat from the economic constitution. Quite the contrary, the introduction of the Regulatory Responsibility Bill in 2007 can actually be regarded as an attempt to extend the economic constitution even further. Although it is unlikely that the Bill will pass into law, the introduction of the Bill itself is indicative of the resilience of the economic constitution and, arguably, of the NPM reforms in a supposedly "post-NPM" era. Thus, a closer look at the debates around the Bill might help illuminate changes and continuity in public management reform.

Perhaps the most interesting point about the Bill is the fact that, despite its conspicuously neo-liberal overtone and provenance ${ }^{35}$, it has managed to gain support from nearly all parties except the Greens. Opponents of the Bill argue that its introduction sends "a dangerous signal" that freedom of contract and property rights will be privileged above everything else ${ }^{36}$. While political pragmatism may explain part of the Bill, it also reflects the

\footnotetext{
${ }^{35}$ As Deborah Coddington, an ex-MP of the Act party points out, the Bill was in fact drafted by her based on a paper by Bryce Wilkinson of the NZBR, who has been a prominent advocate of the New Right (New Zealand Herald, 01 April 2007)

${ }^{36}$ NZCTU Submission on the Regulatory Responsibility Bill, August 2007 at http://union.org.nz/sites/union/files/Regulatory\%20Responsibility\%20Bill.doc accessed on January 2008
} 
peculiar aversion towards, or even denial of, inevitable value conflicts in the Third Way. Characteristically, the assumed absence of substantive conflicts of values is reinforced by an explicit instrumental logic. According to the Bill's sponsor, "all it does is require that a process be followed and information be supplied, which has to be a good thing". And in this sense, the Bill simply does to law what the Fiscal Responsibility Act did to public finance, by making Parliament and Government "more transparent and more open about their lawmaking"37. Yet the difficulty remains, to what extent can the instrumental values of transparency and openness be separated from the conflicts of substantive values? How, for instance, can the regulators be "transparent" about the taking of private property, without subscribing to a certain conception of private property rights? These are old questions, which apply equally to the FRA as they do to the Bill. What is striking about the Bill, however, is an apparent willingness to downplay the centrality of these perennial value conflicts in spite of diversity of values in an MMP environment. The point is not that these conflicts are inherently irreconcilable, but rather the pretended consensus risks foreclosing opportunities for debate and thus genuine reconciliation of deep-seated differences.

Predictably - this is the second point - the Bill overlays with the notion of "community" the reified economy at the centre of the two other pillars of the economic constitution. Indeed, there was not a single reference to the "economy" during the First Reading of the Bill, compared with several to "community". But community, naturally, means different things to different people: to one MP, "a collective notion of the power of ordinary people to make a better world", to another on the other end of the political spectrum "30-odd consumers"38. "The community is where we start from", says the former. But whose community? Thus, despite the rejection of a reified notion of an economy, there appears to be a tendency to overlook and underestimate the problem of reification, only to reinvent it in different forms. Such a tendency manifests itself in other ways, for instance, in the

\footnotetext{
${ }^{37}$ NZPD, 27 June 2007

${ }^{38}$ ibid.
} 
discourse of regulation, with more than a hint of contradiction. On one hand, it is acknowledged by the Bill's promoter that the red tape of one member "might be another member's good law". On the other, terms such as "cutting red-tape" or "improving regulatory quality" are talked about as if they are unambiguously good things in themselves, regardless of whose red-tape is to be cut, or whose quality of regulation is to be improved. It is as if regulation, like inflation, has certain generic and optimal "qualities", which can be specified independent of the political conflicts they nearly always embody.

And finally, issues of power and legitimacy are unsurprisingly absent from such a discourse. When power is talked about at all, it is conveniently associated with "the state" - another reification - and with an implied dislike. There is little discussion about power in other forms, such as power of the "financial markets", or the power of various "communities", against which the power of the "state" is a positive counterbalance. Yet, power remains at the heart of the issue. As a submitter on the Bill argues, commenting specifically on the compensation for property taking:

The beneficiaries of any such provision would be mainly big business interests seeking to avoid regulatory restraint upon their exercise of market power at the expense of consumer and/or competitors, and seeking to portray state action in defence of the weak against the strong as in some sense an illegitimate extension of the appropriate state, and an encroachment upon the alleged property right of a monopolist to enjoy the fruits of its exercise of market power ${ }^{39}$.

There is a broader point in this, that is, neglecting the issues of power risks reinforcing the inequality of power despite and often in direct contradiction to its rhetoric of empowerment. Indeed, one of the interesting, and perhaps unintended, consequences of the Bill is that for a measure designed to constrain the bureaucracy, it actually vests enormous power in

${ }^{39}$ Betram, G, Submission on the Regulatory Responsibility Bill, August 2007 
bureaucrats as the de facto guardians of the regulatory constitution ${ }^{40}$. And this inevitably affects, as it did for the Reserve Bank Act, the relative priority between bureaucratic expertise and democratic legitimacy.

To put it in another way, the difficulty with the Regulatory Responsibility Bill resonates with the paradox of the Public Sector reforms, that is, as one MP expressed it during the first reading of the Bill, it "feeds bureaucracy in order to slay it" (NZPD, 27 June 2008). And as such it illustrates the continuity between the present reforms and the previous NPM ones, not the least in their tendency to produce "unintended" perverse outcomes.

\subsection{Whither Westminster?}

What implications then will the new waves of reform have on New Zealand's constitutional arrangements, particularly given the gap between the new rhetoric and reality? Do the reforms put a stop to the erosion of the Westminster system of democracy or do they constitute new threats? Is it time to move on to what Ryan (2006b) calls a "post Westminster", "Aotearoa/New Zealand way of governing", whatever that means? These are the issues which will be explored below.

\section{$\underline{\text { Still Sovereign? }}$}

In New Zealand parliamentary sovereignty was pushed to the front stage in 2004 as a result of a heated debate between the Deputy Prime Minister and the Chief Justice, together with submissions to the select committee on New Zealand's constitutional arrangements (Cullen 2005, Elias 2003,

\footnotetext{
${ }^{40} \mathrm{~s} .7$ of the Regulatory Responsibility Bill requires the chief executives of the regulatory agency, the chief executive of the Ministry of Economic Development (or the Solicitor General), and the Secretary of Justice independently to certify compliance with the principles of the scheme and the SSC to assess annually compliance with the Bill. Section 7 (2) (b) specifically states the Minister should give no instructions (other than those disclosed in the statement of responsibility) to the agency that is responsible for the administration of the Act or regulation concerning matters specified in section 6(3).
} 
Constitutional Arrangements Committee 2005). The details of the debates themselves are not particularly relevant here. Nevertheless, they reflected anxiety about the ability of parliamentary democracy to provide certainty for values and rights believed "fundamental". If the judges are justified in their concerns, then the compatibility of the doctrine of parliamentary sovereignty with the new reforms must also be in doubt. The notion of a network of public servants as constitutional guardians of public values, like the notion of judges as protectors of human rights, does not fit easily with the "sovereignty" of Parliament. Such tensions have several practical implications.

In the first place, it suggests that Parliament's legislative power might, and for some should, be constrained further, for example by means of a regulatory constitution, in the interest of good administration. Unsurprisingly, perhaps, there has been little enthusiasm to reassert legislative control over areas deregulated during the NPM reforms, including, for example, employment arrangements under the State Sector Act. The reformers seem to have accepted the "enabling, rather than prescriptive" approach of the reforms while reconstructing the subjects of "enabling" as "public entrepreneurs" rather than market actors. One can think of this approach as a new technology of "self regulation" of the government itself (Hood et al 2000; Bartle and Vass 2007). And as Bartle and Vass point out quite correctly, the new wave of "self regulation" is not to be equated with "deregulation". Rather it allows the reforms to be delivered through largely executive-driven initiatives instead of new formal legislative mandates and, in some cases, takes the pressure off changing the original legislative framework ${ }^{41}$. In other words, the balance seems to remain strongly in favour of the executive, rather than Parliament.

Secondly, the impacts of the new waves of reform on parliamentary control over finance have been highlighted during the controversy around the

\footnotetext{
${ }^{41}$ One example is the Government's attempt to address the shortcomings of the Biosecurity Act 1993 through the Biosecurity Strategy in 2004, which preserves the essential aspects of the regime. Another is the Building Act 1990, which by contrast was considerably tightened following the leaky home saga.
} 
introduction of the Public Finance (State Sector Management) (PFSSM) $\mathrm{Bill}^{42}$. The Bill was a critical piece of second-generation reform. In the words of the Minister of Finance, the Bill would "strengthen the public service, make it more transparent and flexible, allow a more integrated response to complex social problems involving a number of state agencies and invigorate the culture of the state sector". He went on to emphasize that the changes were "more technical than political" and therefore the Government would be seeking cross-party support for the Bill.

For critics of the Bill, however, the proposed changes were anything but non-political. The Clerk of the House voiced strong opposition against a number of provisions in the Bill, and labelled various provisions as "a Trojan horse", "virus-like", and "post-modernism gone mad", while Newberry and Pallot compare the Bill to "a wolf in sheep's clothing" (McGee 2004; Newberry and Pallot 2005).

The problem, according to Newberry and Pallot (2004), lies in "the folly of attempting to build on a constitutionally unsound base". The proposed Bill does not change the basic features of the 1989 Act, such as the output based system, "sectoral neutral" accounting, the departmental baseline, surplus provisions and management of off balance sheet items, and in some cases, actually extends them (Newberry and Pallot 2005; 2006). The Minister of Finance argued, in the pre-introduction briefing on the bill, that the system was "fundamentally sound", and what was needed was simply an enhancement of "flexibility for the Executive" and "accountability to Parliament".

The refusal to reconsider the fundamental principles of the Public Finance Act has created its own problems. For instance the proposal to allow aggregation of votes across portfolio and over multiple years, which reflects the new emphasis on cross-cutting outcomes, has been heavily criticised. The Clerk of the House observes that the rationale for this

\footnotetext{
${ }^{42}$ The Bill was passed in 2004 with significant amendments following public submissions. The discussion unless stated otherwise refers to the Bill as it was drafted.
} 
provision seems to rely heavily on "departmental convenience", rather than needs for parliamentary control. For Newberry and Pallot (2005; 2006), the proposal "may enhance cooperation, but it reduces individual responsibility and accountability". But the difficulty is that to take the constitutional implications of these changes seriously inevitably raises broader questions about the Public Finance Act itself that the Bill sought to amend. While these specific changes could be undone - and they were, in the end - to change the official mentality that tends to view political and constitutional issues as simply irrelevant to public management is a much harder task, especially when such an attitude remains firmly entrenched in legislation that underpins the public finance system.

The Bill raises further issues, which not only affect parliamentary control over finance, but also impact directly on its ability to scrutinise the Executive. The issues include clauses which would provide legal grounds for withholding information from Parliament, if such information could be withheld under the Official Information Act or if it would restrict the statutory obligation or right of officials to act independently. The Bill also contained proposals to remove the term of Estimates and supplementary Estimates, ostensibly in order to allow for "innovation" in the presentation of financial information. There were also attempts elsewhere in the Bill to restrict the convention of ministerial responsibility to those matters for which a Minister has legal control. The immediate effects of these provisions collectively on Parliament's right to information, which is unlimited at least in constitutional theory, are obvious and potentially significant, but its flow-on impacts should not be overlooked too. As McGee argues, there is a danger that such provisions might be "unthinkingly duplicated as a standard clause in all legislation in the future".

This is not only an illustration of an extraordinary degree of constitutional illiteracy on the part of officials; it also reflects the same old paradox between the attempt to improve "transparency and accountability" through 
managerial means, and the resultant erosion of democratic accountability to Parliament.

Critics' concerns appear to be confirmed by experiences with the new system over the last few years. The Auditor General, for instance, recently expressed his disappointment that data required for the review of information prepared by agencies in response to changes over 2002-2004 is still "not prepared and reported on as robustly as it ought to be to serve external user needs" (Brady 2008). Parliamentarians themselves seem equally unmoved by the prospect of the reform. The Social Service Committee for instance appeared mildly enthusiastic about the new initiatives in its 2003/04 reports on Vote Child Youth and Family and devoted one entire paragraph to "managing for outcomes" and "intervention logic". "Whole of Government" warranted two sentences two years later. But such enthusiasm, fragmentary as it was, soon receded. Parliamentarians seem preoccupied as ever with perennial problems ranging from staff turnover to the competing needs between children and their families, rather than the neatly devised strategy in the departmental Statement of Intent (CYF 2004, 2005, 2006).

The advocates of the reform might argue that this is not necessarily a problem, as no single set of information is ever satisfactory for all potential users. Information on outcome, in this sense, is a better starting point than output or input and one step closer to what truly matters. This may seem indisputable for most. But it overlooks a fundamental point: the problem is not just what matters, but who decides what matters in the first place. This brings the difference between managerial and political perspectives to the forefront.

The problem can be illustrated by examining more closely the claim of improved accountability and transparency. Ryan (2004:42) for instance maintains: 
The value of $\mathrm{MfO}$ is that it enables managers and analysts to provide Ministers and parliamentarians with information on something they are vitally interested in - policy outcomes. The adversarial tone of Westminster-derived polities often disguises the fact that many Ministers and parliamentarians really are interested in outcomes their arguments are often more about different platforms for achieving them than outcomes themselves. Meaningful outcome information also helps them to do their jobs and as MfO matures, there is more than a faint possibility that public debate and discussion will increasingly focus on substance rather than the form.

Most, if not all, parliamentarians would no doubt dispute that it is a "fact" that the differences between them and their parties are concerned with means rather than ends, or form rather than substance. It is precisely such irreconcilable conflicts over ends of which little is "known" and settled that makes information and the right to know so critical for parliamentarians ${ }^{43}$. For this reason too they are legitimately concerned with every act of government, regardless of whether such acts or consequences are classified as inputs, outputs or outcomes.

The new managerial vision, by contrast, has a different conception about what information is for and how it is to be provided. At its heart, "what matters" is taken for granted, if rarely explained. Provision of information, therefore, is "instrumental" in a sense that it tells a story the end of which is known. And, in spite of fashionable talk about a discursive turn, what matters is actually the doing rather than the talking. Hence the quality and quantity of information, as well as the means through which it is to be provided, can be specified so that "better" information can be provided. And more importantly it should be provided in a way that is consistent with the whole outcome focused managerial system. A right to information, under this view, is simply irrelevant, if not counter-productive.

\footnotetext{
43 'How do I know what questions to ask and what papers to ask for if I don't know what I don't know?' Jim Hacker Yes Prime Minister, BBC.
} 
Therefore, improving provision of information to Parliament by removing its right to know does not make sense from a political perspective. It does make sense, however, if the objectives are really about steering governments towards good outcomes for which provision of information and parliamentary scrutiny are both means to that end. Thus, rather than assisting parliamentary scrutiny, the new initiatives, just like those that went before, risk undermining it.

\section{Accountability or Responsibility?}

Part of the new reforms is clearly an attempt to move beyond managerial accountability. While this opens up opportunities for reversing the erosion of responsibility, the difficulty is that such attempts are often conceived as an alternative to both managerial accountability and ministerial responsibility. Pressures are clearly mounting for constitutional conventions to adapt to the new "reality" (Ryan 2006b; 2008). What exactly then needs to be changed and to what ends?

There have been many different attempts to move beyond managerial responsibility. The mainstream approach, consistent with the general spirit of the new reforms, does not require a fundamental revision of managerial accountability but argues that the focus must be shifted from outputs to outcomes and from individual agencies to collaborative networks. This means adding "a layer of accountability on top of the now familiar concept of accountability for delivering outputs: namely, accountability for 'managing for outcomes'" via techniques such as intervention logic (Baehler 2003). At the same time, the extension of accountability to outcomes and to networks implies a rebalancing of the notions of accountability as "blame and control" and as "strategic dialogue" and "collective learning" especially over outcomes themselves (Ryan 2003; 2004).

The subject of the new accountability (the "what") is defined by the concept of "managing for outcome". This in turn tends to predicate the 
basis for assigning accountability on the standards of causality and controllability. Anderson and Dovey (2003:9), for example, argue:

an agency should not be held formally accountable for things over which it has limited or no control. This is particularly important when considering how to design accountability arrangements under MfO ... At the formal level, accountability needs to be (and is proposed to be) for the processes of managing towards outcomes, rather than the outcomes themselves.

Hence the carefully made distinction between "managing for outcomes" and outcomes themselves. The former can be measured and causally linked to outputs formally under managerial control through performance indicators and intervention logic while the latter cannot. In this sense, the new accountability is not so much an alternative to the managerial mode of accountability as an extension of it. But managerial accountability can only be stretched so far since outcomes, such as improved health or wellbeing, are notoriously difficult to measure. The assumption that accountability necessarily diminishes with certainty poses a dilemma, that in order to make accountability relevant in the face of uncertainty and contingency where conclusive causal linkages are hard to find, there seems to be no choice but to dull the hard edge of accountability. Such an approach does not actually address the output/outcome bifurcation that underlies the accountability gap. While it might quite possibly narrow the gap between outputs and outcomes to some extent, it cannot close such a gap. There is a real risk that the new arrangement might, as Baehler (2003:32) puts it, “just transfer the current system's fetishes and aversions ... up the chain a few notches".

The attempts to locate managerial activities somewhere on a causal chain between outputs and outcomes and assign accountability accordingly often confuses as much as it clarifies. Ryan (2004:100) argues, for instance: 
Managers can be held accountable for managing for outcomes, for managing for means for policy ends, for whether they did manage for outcomes, for whether or not they learned from their experiences and acted.

This looks more like a statement of the problem than its resolution. In an apparent attempt to move away from "outputs", it evokes the familiar dichotomies of means and ends, of management and policy. Such verbal lapse into dichotomous thinking, typical of mainstream advocates of the new accountability, reveals a fundamental hesitation in accepting the full implications of a genuine focus on outcomes.

The rhetorical emphasis of the new accountability falls on its subject rather than its process. As far as the formal accountability system is concerned there appears to be little change. The new version of accountability, according to the Government's Statement of Expectations of the State Sector, is to be based on "setting clear expectations of individuals and assessing performance and assessing performance against expectations". The familiar system of matching ex-post reporting against ex-ante specification and ex-post reporting remains central to the new accountability, as it was during the NPM era.

What is more interesting is the growing interest in the so-called learning paradigm or organisational learning (Anderson and Dovey 2003). Central to this paradigm are the ideas developed by Argyris and Schon (1978; 1996). According to them, organisational learning can be classified as two types. The first, "single loop" learning, refers to detection and correction of errors i.e. the variance between achieved and expected outcomes. This can be seen as another way to describe the notion of accountability as verification, discussed above. The second, "double loop" learning refers to reflection on values, assumptions, actions and those goals themselves. The second type of learning is to be encouraged. 
There can be no doubt that learning opens up new possibilities that a narrow concept of accountability as verification lacks. But the difficulty is that learning is often presented as a substitute for accountability itself. This is further complicated by the fact that in popularised accounts the concept of learning has become highly normative and (positively) value-laden, much like the once fashionable "management". Fiol and Lyles (1985:803), for instance, state that "organisational learning means the process of improving actions through better knowledge and understanding". Ryan (2003:9) similarly asserts that "the term [collective learning] refers to the common sense of collective experience, the knowing-how to make desirable and agreed things happen and to judge whether or not the strategies are working". And it is reflected in practice by the currently fashionable emphasis on "know-hows", "what works" and so on. Too much accountability, it seems, might be counterproductive because it crowds out valuable learning activites.

This is a false antinomy, however. And it poses several difficulties. Firstly, the argument for learning often rests upon an instrumental premise in a sense that its importance is justified directly or indirectly by good outcomes, such as better policies. Whether these promised outcomes would be delivered notwithstanding, an immediate problem is that it does not and cannot override - at least not automatically - the priority of certain substantive values such as democratic legitimacy upon which the centrality of political accountability rests.

Secondly, because of its instrumental nature, the concept of organisational learning cannot stand on its own. It has to be built on rich assumptions about substantive values. The liberal use (and sometimes abuse) of terms such as evidence, practical knowledge, common sense or reflection still raises questions about what counts as knowledge or evidence. It suggests that the process of learning is just as much vulnerable to taken-for-granted assumptions, unintended consequences and oversimplification as the policymaking or public management that it is supposed to improve. In 
other words there is a danger in treating organisational learning itself as if exempted from the critical reflection of "double-loop" learning.

Thirdly, as some critics have already pointed out, a fundamental flaw of the learning theory is its frequent unwillingness to face issues of power and control (Fielding 2001). Whilst most of these criticisms have focused on issues within private organisations, it is even more pertinent for the context of public bureaucracies. Learning for these organisations is necessarily about the exercise of coercive power. The metaphor of learning therefore must be applied with care. The society in which they operate is neither a laboratory nor a classroom. And policy-making is not a harmless pursuit for truth or knowledge, even if sometimes it may seem as such. Organisational learning, just like management, inevitably has political consequences. Learning does not excuse political responsibility for power, particularly in disasters such as Cave Creek, or even the Holocaust, whatever valuable lessons public organisations might learn from them.

Finally the theory of organisational learning often - and sometimes unwittingly - exhibits a veiled anti-political tendency evident in many seminal texts on the subject such as Peter Senge's fifth dimension (Smith 2001). This partly reflects the private sector context in which the theory was developed, but there is also frequently an intimate underlying connection with communitarian political philosophy. This is unsurprising; perhaps only through such an approach can organisational learning circumvent the problems discussed above about power and legitimacy. The rhetoric of communities of practice with shared vision engaging in collective recursive learning through strategic dialogue typically glosses over conflicts between these communities.

Thirdly, if NPM styled managerial accountability may actually reinforce the pathological "rule of nobody", does the new wave of reform offer a clearer picture of who is accountable and responsible for bureaucratic actions, 
and for spectacular failures like Cave Creek? The answer, as will be explained below, is no.

This is not to say that reformers are unaware of the problems with managerial accountability. Quite the contrary, the reformers understand all too well that the shift to managing for outcomes and joint work clearly poses fundamental challenges to the allocations of discretely individualised accountability and responsibility, which is absolutely dependent on clear boundaries between outputs and outcomes, and between arms-length organisations. However, reformers seem unable, or even reluctant to go further than acknowledging the problems and the criticisms often fail to challenge the causal logic of control underpinning managerial accountability. Here lies the difficulty: the reforms often fade into a plea for new "things" to be included - outcomes, networks, community values - rather than a demand for change.

None of these however make it any easier to answer the question of exactly who is or are accountable. The various attempts at devising a new system often appear to be variation of an old theme. SSC, for instance, argues:

Outcomes are influenced by many factors. Some are in our control: others are not. Because of this, chief executives are not accountable for achieving outcomes but are held accountable for "managing for outcomes" [Italics added] (SSC 2005b:1).

There is very little reflection on the commitment to "controllability" as a measure of accountability. As for networks, the response appears even more puzzling. Anderson and Dovey (2003:12) suggest that "burdens are shared when working together, so all with a substantial share will be part of the accountability process".

This seemingly simple solution raises more questions: what counts as a "substantial" share? Who should be responsible for how much of a share? 
And it poses the risk that everybody's responsibility can become nobody's responsibility. This is not to suggest accountability must be divided mechanistically. Rather it is to argue that a better method is needed to locate personal responsibility for collective failures, and to recognise that these failures are nonetheless consequences of human actions. And a causal theory of responsibility is intrinsically inadequate for this task. It will simply create new rifts between culpability and lack of culpability. There is inevitably a sneaking suspicion that popular buzzwords such as "network" might just be another excuse for bureaucratic failures, like "systemic failure" for the tragedy at Cave Creek, while turning a blind eye to those persons whose roles are to prevent such failures in themselves and among their subordinates and who are given power and control by the people for precisely that.

There are alternatives, of course and they are worth examining briefly. The first is a new formula of responsibility and accountability - almost the reversal of the famous misquote of "accountable but not responsible" that requires chief executives "taking responsibility for, but not necessarily being held accountable for, the achievement of outcomes" (Cook 2004:28). The idea that one should answer to one or another greater good rather than account to ordinary political institutions is nothing new in communitarian ideology. But this is a false and potentially harmful dichotomy. There can be no argument against bureaucrats having a certain sense of inner responsibility or moral principles of their own. In fact they always have. The real problem is rather the public legitimacy of such moral precepts. It is difficult to see how and indeed why a public official should claim that he or she has behaved responsibly yet refuse to give a full account of his/her actions to the public. And it is not difficult to identify the disastrous consequences of moral arguments of this kind - or to be exact, monologues - which are more self-righteous than public serving. 
The War in Iraq is one example. The 1980s and 90s reform in New Zealand is another. ${ }^{44}$

The second and more promising suggestion is the concept of "vindicative" responsibility. According to Gregory (1998a:533), it refers to voluntary punishment and/or compensation confirming that "a governmental system is actually capable of caring about those who are victimized by its failings." What is at issue here is not what went wrong and why, although they are important, but who should pay. This is not entirely different from a role conception of accountability as advocated by commentators such as Diana Woodhouse. However, the problem lies with its intimate connection with the communitarian philosophy, which places emphasis on the symbolic affirmation of "the community's system of values" (Lucas 1993:98) for this might be interpreted as a dichotomy between political accountability and moral responsibility to a reified "community". As Gregory cautions, vindicative responsibility is not to be confused with "cynical scapegoating" (1998a:534). Yet the question is why not. There is a danger that too much emphasis placed on symbolic sacrifice may just divert one's attention from where real responsibility lies. Indeed, any cursory view of history would suggest that those who were scarified in traditional communities, however noble their nominal status, were rarely those with real power and control. The risk is that the vindicative concept simply legitimises blame-shifting when blame can and should be attributed to those at the top. Similarly, such political responsibility is not necessarily fulfilled by bureaucratic harakiri. In fact it may well be an act of avoiding responsibility as in the case of German and Japanese war criminals playing to their dubious sense of moral responsibility. In other words, vindicative responsibility cannot be justified by abstract values such as "humanity" or "justice", nor should it be ritualised in forms such as automatic resignation; it must ultimately be

\footnotetext{
${ }^{44}$ One is reminded of Gregory's criticism of the so-called 'public argument advising' that attempts to justify both cases:

The conditional statement here - 'if presented' - is surely contradictory. How can an example of 'public argument advising' be considered 'stellar' if in fact there is little or no public (as distinct from private discussions among the elite) argument that results from it? If, in other words, the advice is democratically sterile? (Gregory 2005b)
} 
determined through the political process, for which accountability is necessary. Otherwise it will simply become an empty ritual.

What one could conclude from the analysis above is that the invention of new concepts is unnecessary. The convention of ministerial responsibility addresses effectively the flaws discussed above. At the heart of it lies a very simple and straightforward answer to the question of who should pay and how: public officials should be held accountable and responsible for their roles in exercising coercive power and control to the extent, and in a manner, determined by the democratic process.

\section{$\underline{\text { A New Bargain }}$}

The issue of "public service bargains" (Hood and Lodge 2006) - in particular, the principle of political neutrality - lurks behind the controversy surrounding the Madeleine Setchell affair in $2007^{45}$. What is of interest here is not the particularities of the affair itself, which have been extensively covered elsewhere, but rather the broader issues raised in its aftermath.

Perhaps the first point to note is that, as the State Service Commissioner puts it:

None of the lessons outlined above are new. None of these reflect any new understanding of public service. None of them have been affected by any change in society, political processes or technology. They can all be found in guidance offered in recent and earlier years

\footnotetext{
${ }^{45}$ The details of the affair have been well covered by two inquiries (SSC 2007; Hunn 2008). The central issue relates to the dismissal of Ms Setchell by the Ministry for the Environment as a result of her partner's employment in the Leader of the Opposition's office as senior Press Secretary. The affair involved the Chief Executive of the Ministry for the Environment, the State Service Commissioner, and the Minister, all of whom resigned in its aftermath. However, the minister's resignation is arguably because he lied to Parliament over the affair, rather than misconduct in the affair per se. The resignation of the State Services Commissioner is not clearly tied to this episode either.
} 
by myself or my predecessors, by the Auditor-General and in the Cabinet Manual (SSC 2007c:13).

The Commissioner is right, in a sense. But it begs the question. The point is not so much about new lessons or new understandings, but rather why senior officials have chosen to put aside longstanding conventions and protections designed to help them manage precisely such difficulties, especially given the flurry of initiatives to restore public values, including political neutrality, as part of the reform.

The Setchell affair, seen in this light, provides a timely reminder of the perils of ignoring old problems. And one such old problem is the tension between responsiveness and responsibility. As Eichbaum and Shaw (2008a) correctly point out, one aspect of the controversy is that "the actions of the Chief Executive of the Ministry for the Environment were more responsive (and less responsible) than they might have been". This of course is not new. Indeed the behaviour of senior officials might become a little more understandable if one considers longstanding concerns about the implications of contractual pressures on public servants to be more responsive for their responsibility to be politically neutral (Boston et al 1996; Saunders 2008). So long as such contractual arrangements remain firmly in place, it is difficult to see how the effort to reinforce political neutrality and other distinctively public values can be any more than, as Hicks (2007) puts it, a "clip-on, confined largely to a code of minimal conduct".

The problem is reinforced by considerable confusion over the meaning of political neutrality. The old dichotomous thinking of "neutrality" as apolitical competency vis-à-vis political influences remains, for example, in Jane Clifton's assertion that "the bureaucracy is there to implement policy, not politics" (Clifton 2007). What is more troubling perhaps is that the dichotomy is dressed in more respectable terms, such as Laking (2008)'s distinction between "advice" and "consult", than the naked reality. Chief executives, as Tanner argues, are required to "ride the boundary between 
the political role of the Minister and the administrative role of the department". And for this reason "advice" simply cannot be regarded as reporting on fait accompli of something done in isolation but must inevitably be a part of dialogue between Ministers and chief executives. Such misunderstandings, old and new, simply add to the myth of "apolitical competency", which arguably caused the tension between "responsiveness" and responsibility in the first place.

The Setchell affair also raises question about the role of political advisors, although the controversy, as Eichbaum and Shaw (2008a) observe, probably has little to do with the actions of particular political advisors. Nonetheless it reflects the uncertainty and anxiety about the implications of the third force of political advisors for the bargain between Ministers and officials. The advent of political advisers does not necessarily change the fundamentals of the Westminster system, and may indeed serve a legitimate and useful function (Eichbaum and Shaw 2003; 2008b). Yet the question is whether reliance on political advisors is an adequate substitute for the political, but non-partisan, role of officials, as the Setchell affair highlights.

What is perhaps still more troubling is the emergence of "communication advisers" from within the bureaucracy. As the Minister of Agriculture and Forestry observes during the inquiry into the Setchell affair:

The role of "communication advisers" and "press secretaries" had developed to be very different from what it might have been in the past because it increasingly involved communication strategy (and sometimes highly political strategy) rather than mere reporting (Hunn 2007:40).

Yet paradoxically political communication has become increasingly less a "political conversation amongst citizens" and more a professionalised task of organisation and management in the "so-called media society" (Habermas 2006). The rise of communication advisors can be regarded as 
a bureaucratic response to this general "de-politicisation" of political communication $^{46}$. In the process it invokes the familiar dichotomy between politics and administration. The specific problem here is that attempts to depoliticise what is after all exercise of power itself creates a risk of politicisation from within, and such attempts inevitably increase the pressure of politicisation as politicians seek to re-establish control. Thus, while one might deplore the actions of politicians during the Setchell affair, an insistence on stopping politicisation from the outside while ignoring the problems posed by the role of communication advisors itself, will do nothing to resolve the dilemma.

The upshot of all this is that it actually affirms the importance of political neutrality. Partisan political advisors or "apolitical" communications advisers cannot usurp the constitutional role that public servants play, as political actors. What is needed is not only to understand the emergence of "new" forces within the political arena, but to grasp and indeed insist on the old principle of political neutrality, that is, public servants must be nonpartisan, rather than pretending to be "apolitical".

Indeed it could be argued that the Setchell affair evidenced not so much "politicisation" as the failure of officials to fulfil the requirements of political neutrality in a more positive sense, that is, the duty of loyalty. The controversy is a reminder that sometimes the political needs of Ministers are better served by the courage of officials to offer free and frank advice, than the excessive responsiveness engendered by a contractual culture.

Contractualism is not the only threat to free and frank advice, however. It may also come under pressure from the new reforms in which there is a tacit acceptance, if not expectation, of a role for officials independent from their political masters. The paradox is that the willingness of officials to publicly justify their own actions on their own, as occurred in the Setchell

\footnotetext{
${ }^{46}$ One of the protagonists of the controversy, Erin Leigh, has expressed this idea of 'depoliticised' communication by arguing that 'every memorable moment in history has started or ended in a speech. It is speeches, not politics that start and end wars; it is speeches, not policies that can bring about radical change within a nation'.
} 
affair $^{47}$, might actually undermine the collective responsibility of officials and Ministers. The attempts to construct a new and independent basis of bureaucratic legitimacy too often fall short of their promise and may have a deleterious impact on the legitimacy of the government as a whole. Consider, for instance, the proposal by Baehler (2005) of a "Public Argument" test, which requires officials simply to present "a coherent set of propositions that lead from premises to a policy conclusion" without regard for actual rationales behind particular policies that cannot be publicly justified. But as Gregory (2005b) argues, the hypothetical policy analysts still face "a compelling moral dilemma", in hard cases such as the Iraqi War, either to be "willingly complicit in an act of public deception, or to refuse to be complicit in what they might consider a war crime". The risk is that such "public arguments" might displace political arguments where moral claims can be discussed. It may actually expose officials who find themselves under greater political pressure to compromise with "the truth", while allowing politicians to get away with "plausible deniability" by shifting responsibility and blame onto "independent" officials. The Iraq WMD affair and the "Children Overboard" affair illustrate the very real danger of this approach (Mulgan 2006). The point is that the safeguard of free and frank advice does not lie in the dichotomy between politics and administration.

What then about leaking? This aspect of loyalty seems to have received least attention in the aftermath of the Setchell affair. Yet the central role played by the media and the apparent irrelevance of the formal channels of redress lend support to the observation by James (2001) that leaking is increasingly viewed more as a matter of course than an exception ${ }^{48}$. Arguably, both cases are not black-and-white cases where leaking is

\footnotetext{
${ }^{47}$ The attempt by the State Service Commissioner to diffuse the controversy by placing an op-ed piece in the Dominiion Post without consulting the minister is an example of this, which not only fails to address public concerns, but also creates unnecessary diversion and confusion about the lines of responsibility.

${ }^{48}$ The Public Disclosure Act received no reference in the subsequent inquiries. Nor was there evidence of complaints being raised through internal processes against the actions of the Chief Executive or the alleged politicisation prior to the "dam bust" of media interests (Hunn 2008). The related controversy around the employment of Clare Curran at the Ministry for the Environment was first raised through the media as an exclusive interview, a year after the protagonist, Erin Leigh, resigned "in protest" at the alleged political appointment (TV3 21 November 2007).
} 
unambiguously in the public interest. That is not to criticise the course of actions of the protagonists, but to argue that the moral ambiguities that leaking inevitably involves should not be ignored. It is questionable, for instance in the more "grey" case of the selective leak of potentially prejudicial information by a major daily on the alleged "terrorist" conspiracy, whether such leaks are intrinsically in the public interest.

While the changes discussed above do not in themselves constitute a new bargain as such, unlike the previous NPM reforms, they do demonstrate clearly that the contractual bargain has not been seriously challenged by the new reforms. Moreover, the changes show signs of a new bargain, close to Hood and Lodge (2006)'s 'trustee' type, in which is slowly emerging a different role of officials as "platonic guardians of public interest" increasingly independent from their political masters. The analysis above shows however that the combination of these two assaults on the traditional bargain may have actually exposed the public service to greater, rather than lesser, risk of politicisation. 


\section{Conclusion}

Arguably the most important conclusion from this exercise in reconciling the tension between bureaucracy and representative democracy is that politics matters in the study of public management. Politics is more than just a "context". It is the heart of the matter. And conversely, public management forms a distinctive, yet integral, part of politics.

The thesis therefore began by asking what sort of politics is appropriate for a modern society. This question was pursued in chapter 2 with a defence of political liberalism against its libertarian and communitarian critics. It argued that a liberal political order that recognises a plurality of values, the dialectical relationship between individuals and society, and the centrality of politics, remains essential to maintaining the commitment to individual autonomy and social equality.

Chapter 3 examined the role of bureaucracy within this liberal political order. It looked to Max Weber and J S Mill who wrote about bureaucracy from different angles. The lessons drawn from Weber's and Mill's analyses are still relevant. In the first instance, they show that democracy needs bureaucracy, both for its "efficiency" - that is, instrumental certainty - and its impartiality in the collective pursuit of democratically chosen ends. And yet, secondly, the problem is that these benefits of bureaucracy inevitably intensify tensions already inherent in liberal-democratic politics between autonomy of choice and a chosen "good life", between individuals and "the collective", and between democratic politics and authority. Weber and Mill show that it gives rise to new problems in forms of goal displacement, dehumanisation, and the displacement of politics by bureaucratic expertise, all of which serve to conceal these old fault lines. Such tensions are not irreconcilable. Quite the contrary, to interpret the problem of bureaucracy in these terms allows one to see the solution that is already there, namely, in reasserting the predominance of liberal democracy over bureaucratic expertise. 
This leads to the Westminster constitution, discussed in Chapter 4, which provides the means to this end. This thesis defends the Westminster constitution because it best gives effects to the centrality of democratic politics, as liberalism demands, and highlights the importance of safeguarding these constitutional principles in constraining bureaucratic power. The discussion provides a reminder of a basic fact, which should not be ignored yet often is overlooked, that political power can only be controlled politically. What critics have often missed is that the point of the Westminster constitution, as a political constitution, is not to "control" bureaucracy as such, but to subject bureaucratic power to political scrutiny and therefore to political control. Indeed the pursuit of democratic control of bureaucracy by disregarding the very principles of liberal democracy - a case of "goal displacement" perhaps - would be not only futile but foolish. There is no effective substitute for politics and the political constitution in a liberal democratic order.

Part I thus established a theoretical model that pulls together the political, bureaucratic and constitutional perspectives. The place of bureaucratic organisations in a liberal-democratic order is that it must be subjected to political control, exercised amongst other things through a political constitution. Moving on from this foundation, Part II turns the attention to the Public Sector reforms in New Zealand.

Firstly, Part II located the public service reforms within the ideological shifts. It was argued that, instead of the label of "socialism without doctrine", the Welfare State was to be understood as an experiment in liberal politics. This is not to say that the Welfare State itself was in any sense "liberal", but rather the evolution of the Welfare State in New Zealand was partly driven by its commitment to liberal values, which sustained the legitimacy of different experiments by those on the left as well as the right.

This journey is interrupted and indeed partly reversed, so the thesis argued, by the advent of the New Right in New Zealand. A perception of 
crisis enabled the New Right to assert hegemonic control over a pluralistic polity with the slogan of "there is no alternative". It attempted to rationalise the varied and contradictory values and aspirations of the Welfare State by appealing, paradoxically, to an eclectic collection of beliefs in the invisible hand of the markets, in "small town values", and in the possibility of freedom of individuals alone. It tried to convince the people that there is no such thing as society, but markets, families and other institutions that, supposedly, simply exist and always have existed. And it practised a new style of politics that was more "business-like", more technocratic and less concerned with the need for conciliation and compromise. The New Right promised certainty, but it extracted a high price - the elimination of the possibility of alternative values, of relations with others, and of political actions and political freedom.

At the turn of the century New Zealand witnessed another change of direction from the New Right to the Third Way, this time less radical and more pragmatic. But there is no resumption of the journey towards liberal ideals. The communitarian rhetoric of the Third Way may have attempted to position itself as diagnostically opposed to the New Right. Yet in reality it is more of a "top up" than a radical departure. The poverty of politics limits the possibility of overcoming the New Right legacies.

Secondly, it is perhaps easier to understand, against the decline of politics, the rise of bureaucratic power despite, and partly because of, the reforms to banish or to modernise, bureaucracy. The thesis began with reassessment of the traditional New Zealand public service under the Welfare State, and argued that it should be viewed critically. The traditional public service, although it embodied essential characteristics of the Weberian bureaucracy, was also a repository of political values and aspirations central to the Welfare State, which served to problematise and limit its bureaucratic side. Perhaps the most important point from this is that the traditional model evidenced the possibility of democratic control over bureaucracy by asserting the centrality of politics itself. 
This prepared the ground for the arguments around the NPM reforms. The reforms were supposed to make the bureaucracy, above all, more "business-like" and like its predecessor in 1912 it looked to the private sector for ideas. The reforms radically changed the way bureaucracy operated. Public servants were transformed into managers; the commandand-control departments became contracting and competitive agencies; and the volatile bureaucratic politics of the Welfare State gave away to a new Economic Constitution. However the attempts to "de-bureaucratise" the bureaucracy by making it more "rational" and "efficient" and simultaneously removing "irrational" political elements are, as this thesis demonstrated, oxymoronic. From a Weberian perspective, the focus of the reforms on instrumental values such as efficiency and certainty lent itself to "goal displacement". The mechanistic approach, moreover, was vulnerable to problems of reification and dehumanisation by calculation and measurement. Aversion to politics rendered it open to "capture" by technocratic politics amongst others. In short, it made the public service more, rather than less, bureaucratic in the Weberian sense. But this is not simply because the NPM reforms had managed to break the shackles of politics, but rather, as this thesis has argued, the politics of the New Right had already undermined the vitality of liberal democratic politics and therefore enabled the deepening of bureaucratisation.

The absence of political changes partly explains why the pragmatic changes after 1999 have failed to reverse deepening bureaucratisation in any fundamental way. Instead of efficiency, the new reforms seek in other values some source of instrumental certainty. Instead of mechanistic images of reified market relations, the reforms look to the icons of "organic" trust, networks and communities that say nothing about the human relations underpinning these imagined "organisms". And in place of technocratic power based on neo-classical economics, they promise to empower everybody and anybody through ever more sophisticated technology such as intervention logic. Questions of power, according to these formulations, supposedly do not arise. The problem of the new reforms is as much their failure to reverse the deepening bureaucratisation 
under the NPM reforms as their staving off possible challenges and alternatives.

Thirdly, there are implications for the Westminster constitution, of which the public service is a constitutive part. The political constitution was ineffective, as this thesis has argued, under the Welfare State. However, the worst-case diagnosis of the political constitution is not justified. This thesis has argued that the ineffectiveness of the political constitution was a consequence of the paralysing of the process by majoritarianism, rather than the constitution itself. Also, even given the paralysis induced by the dominance of majoritarianism, the political constitution did ensure an ultimate check on bureaucratic power.

Part of the appeal of the NPM reforms was their promise of strengthening the constitution by enhancing Parliament's control over finance, by making Ministers and managers more clearly accountable, and by insulating managers from politics. This thesis has argued that those measures not only misinterpreted the rationale of the political constitution, but also fatally undermined it. The enhanced "transparency" of financial information did not compensate for Parliament's loss of access to information useful in its political role as the scrutiniser of the government. The strengthening of managerial accountability similarly restricted the effective functioning of political responsibility by Ministers and public servants. The replacement of partisan-neutral public servants by apolitical managers was based on ignorance of the constitution leading to a misunderstanding of the meaning of political neutrality, opening the public service to politicisation by "apolitical" partisan ideologies. Again, this was by no means a result of the public service reforms, but rather a consequence of broader political changes.

Perhaps because these threats to the political constitution are rarely acknowledged, there have been few attempts to address them in a supposedly post-NPM environment. Quite the contrary, modifications to the NPM changes take place largely without reference to the constitutional 
principles. There are improvements here and there. Yet attempts to build on a highly inadequate foundation have done very little to bridge the gap between the NPM reforms and constitutional expectations.

Is there no escape from the "fate in our times", as Max Weber bemoaned, that is "characterized by rationalization and intellectualization and, above all, by the disenchantment of the world" (Weber 1947:155)? The poverty of politics, the deepening of bureaucratisation and the erosion of the political constitution certainly seem to point to a discouraging tomorrow. The most important contribution this thesis has made, perhaps, is to suggest the possibility that such a fate is not inevitable. There is no need to retreat to the mythical realm - after all the fantasies of the market or the community had all been tried. Rather what is needed is "faith" in human beings themselves and in the possibility of politics, particularly at a time when politics has become increasingly subservient to the imperatives of "what we can afford" or "what works".

On a more practical note, this thesis suggests that, in order to rehabilitate the public service and public service reforms, it may be time to abandon the pursuit of efficiency or effectiveness or "good administration"; to reject the tendency to conceive human relations in reified terms; and to renounce the unquestioned faith in technocratic knowledge. Rather the reforms must be guided by asking how bureaucracy can work with democracy in order to maximise individual autonomy and social equality, to ascertain that the convenient shorthands invented to describe the complexity of collective actions remain in the end human, and to ensure that bureaucratic expertise does not usurp politics.

This thesis is only a beginning towards this end, which given time and space constraints, has left undeveloped several lines of inquiry. It points to a future research agenda.

In terms of the theoretical foundation, it would be useful to more fully conceptualise political liberalism in the context of "hard cases" and 
investigate their implications on public management. In this respect, the study by Haque (2002) of the "War on Terror" on public management has already made some headway. In New Zealand, Maori-related issues, which have always posed challenges to liberal principles, open another opportunity to test these principles and practices.

In terms of practical changes, the post-NPM reforms, as argued above, have already weakened the TINA mentality. The issue however is to ensure that the search for alternatives does not make the same mistakes as the previous reforms. It should include, for instance, questions such as:

- How can the value-based approach to public management be aligned with the plurality of values in society, together with respect for democratic institutions, and not just consist of a different laundry list of presumed goals?

- How might the new partnership paradigm be conceptualised to bring public servants closer to the people themselves, without the entrapments of reification, in a manner that is just, inclusive, and for all citizens?

- How is it possible to restore public confidence in democratic politics and in the people themselves as political actors, especially given the seductive appeal of technological solutions to social problems?

- How can Parliament, as the Hansard Society (2001) advocates, assert itself "at the apex" of a system of scrutiny over a fragmented and complicated polity? For instance, how can the role of select committees, which have proved to be an effective means of scrutiny and public engagement, be further enhanced? How can Parliament 
rebuild its credibility while retaining its distinctiveness as a political, representative, and deliberative institution? ${ }^{49}$

- What can be done to improve the willingness of parliamentarians and the public themselves to hold the government responsible for its acts, and to encourage them to make use of existing channels of accountability and responsibility to do so?

- What is needed to protect the principle of political neutrality particularly against more creative forms of partisan politicisation under the guise of "apolitical" neutrality? How is it possible to encourage positive attitudes towards politics in the public service while safeguarding political neutrality, properly understood?

A future reform of the Public Sector, therefore, might focus less on how to reinvent the bureaucracy, but rather how to revitalise politics and political participation. Through this approach one might discover more effective ways of exerting democratic control over bureaucracy, and conversely reduce the risks of "bureaucratisation" of politics.

\footnotetext{
${ }^{49}$ McRae's 1994 study "A Parliament in Crisis: The Decline of Democracy in New Zealand" (Wellington: Sheildaig Press) provides a good starting point but is in need of updating.
} 


\section{Bibliography}

Advisory Group (2001). Report of the Advisory Group on the Review of the Centre. Wellington, SSC.

Advisory Group (2002). Review of the Centre - One Year On: Getting Better Results for Citizens, Ministers and staff. Wellington, SSC.

Aiken, M. (1994). "Parliamentary Sovereignty and Valuation Accruals: Uncongenial Conventions." Financial Accountability \& Management 10(1): 17-32.

Albrow, M. (1970). Bureaucracy. London, Pall Mall.

Anderson, B. and L. Dovey (2003). Whither Accountability. Working Papers No.18. Wellington, State Service Commission.

Arendt, H. (1963). Eichmann in Jerusalem: A Report on the Banality of Evil. London, Penguin.

Argyris, C. and D. Schon (1978). Organizational learning: A theory of action perspective. Reading, Addison Wesley.

Argyris, C. and D. Schon (1996). Organizational learning Ill: Theory, method and practice. Reading, Addison Wesley.

Ashton, T. (1999). The health reforms: to market and back? Redesigning the Welfare State in New Zealand. J Boston, P. Dalziel and S. S. John. Auckland, OUP.

Auditor-General (1978). Financial Management and Control in Administrative Government Departments: the Shailes Report. Wellington, Office of the Controller and Auditor-General.

Auditor-General (2002). Severance Payments in the Public Sector. Wellington, Office of the Controller and Auditor-General.

Baberis, P. (1998). "The New Public Management and a New Accountability." Public Administration 76(Autumn): 451-470.

Baehler, K. (2002). "Intervention Logic: A User's Guide." Public Sector 25(3): 1319.

Baehler, K. (2003). "Managing for Outcomes: Accountability and Thrust." Australian Journal of Public Administration 64(2): 23-34. 
Baehler, K. (2005). "What are the Limits to Public Service Advising? The "Public Argument" Test." Public Sector 1(3 - 8).

Baehler, K. (2007). Intervention Logic / Program Logic: Toward Good Practice. Improving Implementation: Organisational Change and Project Management. J. Wanna. Canberra, Australian National University Press.

Baehr, P. (2001). "The iron cage and the shell as hard as steel : Parsons, Weber, and the stahlhartes Gehäuse metaphor in the protestant ethic and the spirit of capitalism." History and theory 20(2): 153-169.

Baldwin, J. (1986). Evidence of Things not Seen. London, Michael Joseph.

Bardach, E. (1998). Getting Agencies to Work Together: the Practice and Theory of Managerial Craftsmanship. Washington DC, Brookings Institute Press.

Barrett, P. (2001). Auditing in an outsourced environment, Australian National Audit Office.

Bassett, M. (1998). The State in New Zealand 1840 -1984: Socialism without doctrines? Auckland, Auckland University Press.

Beiner, R. (1988). What's the matter with Liberalism. Law and the Community: the End of Individualism. A. Hutchinson and L. Green. Toronto, Carswell Limited.

Belgrave, M. (2004). Needs and the State: Evolving Social Policy in New Zealand History. Past Judgment: Social Policy in New Zealand History. B. Dalley and M. Tennant. Dunedin, University of Otago Press.

Bell, D. A. (2005). "A Communitarian Critique of Liberalism." Analyse \& Kritik 27: 215-238.

Bellamy, R. (2007). Political Constitutionalism: A Republican Defence of the Constitutionality of Democracy. Cambridge, Cambridge University Press.

Berger, P. L. and T. Luckmann (1984). The Social Construction of Reality: A Treatise its the Sociology of Knowledge. Garden City, New York, Anchor Books.

Berlin, I. (1969). Two Concepts of Liberties. Four Essays on Freedom. Oxford, Oxford.

Blair T and G Schroeder (1999) Europe: the Third Way/Die Neue Mitte, London: Labour party 
Blau, P. M. (1955). Bureaucracy and Modern Society. New York, Random House.

Bohte, J. and K. J. Meier (2000). "Goal Displacement: Assessing the Motivation for Organizational Cheating." Public Administration Review 60(2): 173-182.

Boston, J., J. Martin, et al. (1991). Reshaping the State: New Zealand's Bureaucratic Revolution. Auckland, Oxford University Press.

Boston, J. (1992). "New Zealand's Privatization Programme: Objectives, Principles, Problems, and Outcomes." Annals of Public and Cooperative Economics 63(4): 573-600.

Boston, J. (1995). Inherently Governmental Functions and The Limits to Contracting Out. The State under Contract. J. Boston. Wellington, Bridget Williams.

Boston, J., J. Martin, et al. (1996). Public Management: The New Zealand Model. Auckland, Oxford University Press.

Boston, J., S St John, et al. (1996). "The Quest for Social Responsibility." Social Policy Journal of New Zealand(7).

Boston, J., S. Levine, et al. (1999a). Electoral and Constitutional Change in New Zealand: An MMP Source Book. Palmerston North, Dunmore Press.

Boston, J., P. Dalziel, et al. (1999b). Redesigning the Welfare State in New Zealand: Problems, Policies, Prospects. Auckland, Oxford University Press.

Boston, J. (2000). "The Challenge of Evaluating Systemic Change: The Case of Public Management Reform in New Zealand." International Public Management Review 3(1): 23-46.

Boston, J. (2001). Departmental Secretaries: The New Zealand Experience. Mandarins or Valets? The Changing World of Top Officials. R. A. W. Rhodes and P. Weller. Buckingham, Open University Press.

Boston, J. and C. Eichbaum (2005). State Sector Reform and Renewal in New Zealand: Lessons for Governance. Repositioning of Public Governance Global Experiences and Challenges, Taiwan, National Taiwan University.

Boston, J. (2007). "Responding Comments." Public Sector 30(3).

Bovens, M. (2006). Analysing and Assessing Public Accountability: A Conceptual Framework. European Governance Papers (EUROGOV). 
Bradley, A. (2004). The Sovereignty of Parliament - Form or Substance? The Changing Constitution. J. L. J. D. Oliver. Oxford, Oxford University Press.

Brady, K. (2008). Forecasting and reporting performance - the search for the Holy Grail? After the Reforms, Wellington.

Brash, D. (1996). New Zealand's remarkable reforms: Speech to the Fifth Annual Hayek Memorial Lecture. London, Institute of Economic Affairs.

Brent, J. (2004). "The Desire for Community: Illusion, Confusion and Paradox." Community Development Journal 39(3).

Brown, W. (2003). "Neo-liberalism and the End of Liberal Democracy." Theory \& Event 7(1).

Brown, W. (2006). "American Nightmare: Neoliberalism, Neoconservatism and De-Democratization." Political Theory 34(6): 690-714.

Brubaker, R. (1984). The Limits of Rationality: An Essay on the Social and Moral Thought of Max Weber. London, Allen \& Unwin.

Brunton, W. (2004). Out of the Shadows: Some Historical Underpinnings of Mental Health Policy. Past Judgment: Social Policy in New Zealand History. B. Dalley and M. Tennant. Dunedin, University of Otago Press.

Bryson, L. and M. Mowbray (2005). "More Spray-on Solution: Community, Social Capital and Evidence Based Policy." Australian Journal of Social Issues 40(1): 91-106.

Cameron, W. (2004). "Public accountability: Effectiveness, equity, ethics." Australian Journal of Public Administration 63(4): 59-67.

Campbell, C. and B. G. Peters (1988). "The Politics/Administration Dichotomy: Death or Merely Change?" Governance 1(1): 79-99.

Campbell, G. (1999). Snouts in the trough. Listener. 169: 16-19.

Chapman, B. (1963). The Profession of Government. London, Allen \& Unwin.

Chapman, R. (1992). From Labour to National. The Oxford History of New Zealand. G. Rice. Auckland, Oxford University Press.

Chapman, R. (2000). "Accountability: Is Westminster the Problem?" Australian Journal of Public Administration 59(4): 116-121. 
Chapman, J. and D. Duncan (2007). "Is there now a New 'New Zealand Model'?" Public Management Review 9(1): 1-25.

Cheyne, C., M O'Brien, et al. (2004). Social Policy in Aotearoa New Zealand: A Critical Introduction. Auckland, Auckland University Press.

Christensen, T. and P. Laegreid (2001). "New Public Management: the effects of contractualism and devolution on political control." Public Management Review 3(1).

Christensen, T. and P. Laegreid (2004). The Fragmented State - the Challenges of Combining Efficiency, Institutional Norms and Democracy. Working Paper 3-2004. Bergen, Norway, Stein Rokkan Centre for Social Studies.

Clark, H. (2002). Prime Minister's Address to the London School of Economics.

Clarke, J., A. Cochrane, et al. (1994). Managing Social Policy. London, Sage Publications.

Clarke, J. and J. Newman (1997). The Managerial State: Power, Politics and Ideology in the Remaking of Social Welfare. London, SAGE.

Clarke, J. (2003). Managing and Delivering Welfare. The Student's Companion to Social Policy. P Alcock, A. Erskine and M. May. London, Blackwell Publishing.

Clarke, J. (2004). "Dissolving the Public Realm? The Logics. and Limits of Neoliberalism." Journal of Social Policy 33(1): 27-48.

Clifton, J. (2007). The Setchell Case. NZ Listener. 209.

Condliffe, J. B. (1959). The Welfare State in New Zealand. London, George Allen \& Unwin.

Considine, M. and J. Lewis (2003). "Bureaucracy, Network, or Enterprise? Comparing Models of Governance in Australia, Britain, the Netherlands, and New Zealand." Public Administration Review 63(2).

Constitutional Arrangements Committee (2005). Inquiry to review New Zealand's existing constitutional arrangements. Wellington, Parliament.

Cook, A.-L. (2004). Managing for Outcomes in the New Zealand Public Management System. Working Paper 04/15. Wellington, Treasury.

Craig, D. (2006). "Community Well-Being Strategy and the Legacies of New Institutionalism and New Public Management in Third Way New Zealand." 
Social Policy Review 18(193-218).

Crick, B. (1964). The Reform of Parliament. London, Weidenfeld and Nicolson.

Crick, B. (2005). In Defence of Politics. London, Continuum.

Cullen, M. (2003). "Increased Parliamentary Scrutiny for Air New Zealand." Press Release.

Cullen, M. (2004). Parliament: Supremacy over Fundamental Norms? Public Law Conference, Legislative Chamber, Parliament, Wellington.

Currie, G. and A. Musgrave (1985). Popper and the Human Sciences. London, Springer.

Curtis, B. (2003). Third Way Partnerships: neoliberalism and social capital. Strengthening Communities through Local Partnerships Research Paper 4. Auckland, Auckland University.

CYF (2004, 2005, 2006). Annual Reports. Wellington.

Dagger, R. (2004). Communitarianism and Republicanism. Handbook of Political Theory. F. Gaus and C. Kukathas. London, SAGE.

Dalley, B. (2005). The Golden Weather 1949-1965. Frontier of Dreams. B. Dalley and G. McLean. Auckland, Hodder Moa Beckett.

Dalziel, P. (1993). The Reserve Bank Act. State and Economy in New Zealand. B. Roper and C. Rudd. Auckland, Oxford University Press.

Davies, J. (2007). The limits of joined up government: bringing politics back in. Political Studies Association Annual Conference, University of Bath.

de Maria, W. (2001). "Commercial-in-Confidence: An Obituary to Transparency?" Australian Journal of Public Administration 60(4): 92-109.

DeFilippis, J. (2001). "The Myth of Social Capital in Community Development." Housing Policy Debate 12(4): 781-806.

Denemark, D. (2001). Choosing MMP in New Zealand: Explaining the 1993 Electoral Reform. Mixed-member Electoral Systems: The Best of Both Worlds? M. S. Shugart and M. P. Wattenberg. Oxford, Oxford University Press.

Dicey, A. V. (1915). An Introduction to the Law of the Constitution. London, Macmillan \& Co. 
Douglas, R. (1993). Unfinished Business. Auckland, Random House.

Dovey, L. (2003). Achieving Better Social Outcomes in New Zealand through Collaboration: Perspectives from the United States. Wellington, State Service Commission.

du Gay, P. (2000). In Praise of Bureaucracy. London, Sage.

du Gay, P. (2004). The Values of Bureaucracy. Oxford, Oxford University Press.

Dworkin, R. (2006). Is Democracy Possible Here? Principles for a New Political Debate. Princeton, New Jersey, Princeton University Press.

Eagles, I., M. Taggart, et al. (1992). Freedom of Information in New Zealand. Auckland, Oxford University Press.

Easton, B. (1981). "All the Keynes Men." Listener(23 May).

Easton, B. (1997). The Commercialisation of New Zealand. Auckland, AUP.

Easton, B. (1999). The Whimpering of the State: Policy after MMP. Auckland, Auckland University Press.

Economics \& Strategy Group (2003). Departmental Uptake of the Managing for Outcomes Initiative. Wellington, SSC.

Eichbaum, C. (1999). The Reserve Bank and Monetary Policy. The New Politics: a Third Way for New Zealand. S Chatterjee et al. Palmerston North, Dunmore Press.

Eichbaum, C. and R. Shaw (2003). "A Third Force? Ministerial Advisers in the Executive." Public Sector 26(3): 7-13.

Eichbaum, C. and R. Shaw (2005a). "Why We Should All be Nicer to Ministerial Advisers." Policy Quarterly 1(4).

Eichbaum, C. and R. Shaw (2005b). Is Westminster Dead in Wellington? Ministerial Advisers in the New Zealand Executive. Australasian Political Studies Association Conference, Otago University.

Eichbaum, C. and R. Shaw (2006). If Ministerial Advisors are the Answer, then What is the Question? Issues of Governance and Policy Capability in the New Zealand Context. GovNet International Conference, The Australian National University, Canberra. 
Eichbaum, C. and R. Shaw (2007a). "Ministerial Advisers, Politicization and the Retreat from Westminster: the Case of New Zealand." Public Administration 85(3).

Eichbaum, C. and R. Shaw (2007b). "Ministerial Advisers and the Politics of Policymaking: bureaucratic permanence and popular control." Australian Journal of Public Administration December.

Eichbaum, C. and R. Shaw (2008a). "Politics and Administration: Some Reflections on the 'Setchell Affair' (or Boundary Riding in the Purple Zone)." Public Sector 30(4).

Eichbaum, C. and R. Shaw (2008b). "Revisiting Politicization: Political Advisers and Public Servants in Westminster Systems." Governance 21(3): 327-363.

Elias, S. (2003). "Sovereignty in the 21st Century: Another Spin on the Merry-GoAround." Public Law Review 14.

Ellwood, S. and S. Newberry (2007). "Public sector accrual accounting: institutionalising neoliberal principles?" Accounting, Auditing \& Accountability 20(4): 549-573.

Etzioni-Halevy, E. (2005). Elite with(out) Linkage in the New Millennium: A Challenge to the Elite Theory. Political parties and political systems: the concept of linkage revisited. A. Rommele, D. Farrell and P. Ignazi. Westport: Texas, Greenwood Publishing Group.

Evans, H. (2002). "Scrutinising Government Contracts: A Continuing Order for Document." TABLE 70.

Evans, H. (2007). "Parliamentary Control of Finance: Bringing back the Revolution." TABLE 75: 9-16.

Farmer, D. (1995). The Language of Public Administration: Bureaucracy, modernity and post-modernity. Tuscaloosa, AL, University of Alabama Press.

Fielding, M. (2001). "Learning Organisation or Learning Community? A Critique of Senge." Reason in Practice: Journal of the Philosophy of Management 1(2).

Fine, B. (2001). Social Capital versus Social Theory: Political Economy and Social Science at the Turn of the Millennium. New York, Routledge.

Fiol, C. M. and M. A. Lyles (1985). "Organizational Learning." Academy of Management Review 10(4): 803-813. 
Fitzsimons, P. (2000). Neoliberalism and 'Social Capital': Reinventing Community. AREA Symposium, New Orleans.

Frazer, E. (2007). "Depoliticising Citizenship." British Journal of Educational Studies 55(3): 249-263.

Freeman, S. (2001). "Illiberal Libertarians: Why Libertarianism is not a Liberal View." Philosophy and Public Affairs 30(2): 105-151.

Freiberg, A. (1999). "Commercial confidentiality and public accountability for the provision of correctional services." Current Issues in Criminal Justice(119).

Gajduschek, G. (2003). "Bureaucracy: Is It Efficient? Is It Not? Is That The Question?" Administration \& Society 34(6): 700-723.

Gauld, R. (2001). Revolving Doors: New Zealand's Health Reforms. Wellington, Institute of Policy Studies and Health Services Research Centre, Victoria University.

Gauld, R. and S. Goldfinch (2006). Dangerous enthusiasms: E-government, computer failure and information system development. Dunedin, Otago University Press.

Gill, D. (2008). By Accident or Design - Changes in the Structure of the State of New Zealand. After the Reforms, Wellington.

Gilling, B. (1998). The Ombudsman in New Zealand. Palmerston North, Dunmore Press in association with the Historical Branch, Ministry of Internal Affairs.

Goldfinch, S. (1997). Treasury and public policy formation. The Political Economy of New Zealand. C. Rudd and B. Roper. Auckland, Auckland University Press.

Goldfinch, S. (1998a). "Evaluating Public Sector Reform in New Zealand: Have the Benefits Been Oversold?" Asian Journal of Public Administration 20(2): 203-232.

Goldfinch, S. (1998b). "Remaking New Zealand's Economic Policy: Institutional Elites as Radical Innovators: 1984-1993." Governance 11(2): 177-207.

Goldfinch, S. (2000). Remaking New Zealand and Australian Economic Policy. Wellington, VUP.

Goldfinch, S. (2002). "The Old Boys' Network? Social Ties and Policy Consensus amongst Australian and New Zealand Economic Policy Elites." Policy and 
Society 21(2).

Goldfinch, S. (2004). "Economic Reform in New Zealand." Otemon Journal of Australian Studies 30: 75-98.

Goldsworthy, J. (2005). "Is Parliament Sovereign? Recent challenges to the doctrine of parliamentary sovereignty." New Zealand Journal of Public and International Law(3): 7-37.

Goldworthy, J. (1999). The Sovereignty of Parliament, History and Philosophy. Oxford, Claredon Press.

Gordon, S. (1999). Controlling the State: Constitutionalism from Ancient Athens to Today. Cambridge, MA, Harvard University Press.

Gould, B. (2006). The Democracy Sham: How Globalisation Devalues Your Vote. Nelson, Craig Potton.

Gray, A. (2002). Integrated Service Delivery and Regional Coordination: a literature review. Wellington, Gray Matter Research Ltd.

Greenaway, J., B. Salter, et al. (2007). "How Policy Networks Can Damage Democratic Health: a Case Study in the Government of Governance." Public Administration 85(3): 717-738.

Gregory, R. (1982). "Understanding Public Bureaucracy." Public Sector 4(2/3): 312.

Gregory, R. (1995a). Accountability, Responsibility, and Corruption: Managing the 'Public Production Process'. The State Under Contract. J. Boston. Wellington, Bridget Williams Books.

Gregory, R. (1995b). "Post Reform Attitudes of New Zealand's Senior Public Servants: A Follow-up Study." Political Science 47(2): 161-190.

Gregory, R. (1995c). "The Peculiar Tasks of Public Management: Towards Conceptual Discrimination." Australian Journal of Public Administration 54(2): 171-184.

Gregory, R. (1996a). "Bureaucratic Psychopathology and Technocratic Governance: Whither Responsibility." Hong Kong Public Administration 4(1): 17-36.

Gregory, R. (1996b). Reserve Bank Independence, Political Responsibility and the Goals of Anti-democratic Policy: A political Cri de Coeur in Response to an Economist's Perspective. The GSBGM Working Paper Series. 
Wellington.

Gregory, R. (1998a). "Political Responsibility for Bureaucratic Incompetence:

Tragedy at Cave Creek." Public Administration 76(Autumn 1998): 519-538.

Gregory, R. (1998b). "New Zealand as the "New Atlantis"." Canberra Bulletin of Public Administration(90): 107-12.

Gregory, R. and C. Hicks (1999). "Promoting Public Service Integrity: A Case for Responsible Accountability." Australian Journal of Public Administration 58(4): 3-15.

Gregory, R. (1999). "Social Capital Theory and Administrative Reform:

Maintaining Ethical Probity in Public Service." Public Administration Review 59(1): 6-75.

Gregory, R. (2000). Getting Better but Feeling Worse? Public Sector Reform in

New Zealand. International Public Management Workshop, Wellington NZ.

Gregory, R. (2001). 'Transforming Governmental Culture: A Sceptical View of

New Public Management'. New Public Management: The Transformation of Ideas and Practice. T. Christensen and P. Laegreid. Aldershot UK, Ashgate.

Gregory, R. (2002a). "Governmental Corruption in New Zealand: A View through Nelson's Telescope?" Asian Journal of Political Science 10(1): 10-38.

Gregory, R. (2002b). New Zealand - the End of Egalitarianism? Reward for High Public Office: Asian and Pacific Rim States. C. Hood and B. G. Peters. London, Routledge.

Gregory, R. (2003a). Accountability in Modern Government. Handbook of Public Administration. B. G. Peters and J. Pierre. London, Sage.

Gregory, R. and R. Norman (2003). "Paradoxes and Pendulum Swings:

Performance Management in New Zealand's Public Sector." Australian Journal of Public Administration 62(4): 35-49.

Gregory, R. (2003b). "Political Life is Larger than Intervention Logic." $\underline{\text { Public }}$ Sector 26(1): 4-6.

Gregory, R. (2003c). "All the King's Horses and All the King's Men: Putting New Zealand's Public Sector Back Together Again." International Public Management Review 4(2).

Gregory, R. and M. Painter (2003). "Parliamentary Select Committees and Public Management Reform in Australasia: new games or variations on an old 
theme?" Canberra Bulletin of Public Administration(106): 63-72.

Gregory, R. and J. G. Christensen (2004). "Similar Ends, Differing Means:

Contractualism and Civil Service Reform in Denmark and New Zealand." Governance 17(1).

Gregory, R. (2004a). Dire Expectations but Subtle Transformations? Politicisation and the New Zealand Public Service. The Politicization of the Civil Service in Comparative Perspective A Quest for Control. B. G. Peters and J. Pierre. London, Routledge.

Gregory, R. (2004b). "Political Life and Intervention Logic: Relearning Old Lessons?" International Public Management Journal 7(2): 299-315.

Gregory, R. (2005a). "Yes Minister." New Zealand Books(October 2005).

Gregory, R. (2005b). "Politics, Power and Public Policy-making: A Response to Karen Baehler." Policy Quarterly 1(4): 26-34.

Gregory, R. (2005c). Theoretical Faith and Practical Works: De-Autonomising and Joining up in the New Zealand State Sector. Autonomization of the State: from Integrated Models to Single Purpose Organizations, Stanford University.

Gregory, R. (2007a). New Public Management and the Ghost of Max Weber. Transending New Public Management. T. Christensen and P. Laegreid. Aldershot UK, Ashgate.

Gregory, R. (2007b). "Bringing Back the Buck: Responsibility and Accountability in Politics and the State Sector." Public Sector 30(2).

Griffith, J. A. G. (1979). "The Political Constitution." The Modern Law Review 42(1).

Griffith, J. A. G. (2000). "The Brave New World of Sir John Laws." Modern Law Review 63(2).

Gustaufson, B. (1996). The National Government and Social Change (19491972). The Oxford Illustrated History of New Zealand. K. Sinclair. Auckland, Oxford University Press.

Gutmann, A. (1996). How Limited is Liberal Government. Liberalism without Illusions. B. Yack. Chicago, University of Chicago Press.

Habermas, J. (2006). "Political Communication in Media Society: Does Democracy still Enjoy an Epistemic Dimension?" Communication 
Theory(2006).

Halligan, J. (2007). "Reintegrating Government in Third Generation Reforms of Australia and New Zealand." Public Policy and Administration 22(2): 217238.

Hansen (2005). "Representative Government and Network Governance - In Need of Co-governance: Lessons from Local Decision Making on Public Schools in Denmark." Scandinavian Political Studies 28(3): 219 - 237.

Haque, M. S. (2001). "The Diminishing Publicness of Public Service under the Current Mode of Governance." Public Administration Review 61(1).

Haque, M. S. (2002). "Government responses to terrorism: Critical views of their impacts on people and public administration." Public Administration Review 62(5).

Harlow, C. (1999). "Accountability, New Public Management and the Problems of the Child Support Agency." Journal of Law and Society 26(2).

Harris, P. (1995). "Intimacy in New Zealand Politics: A Sceptical Analysis." Political Science 47(1).

Harriss, J. (2002). Depoliticizing Development: the World Bank and Social Capital. London, Anthem Press.

Harvey, D. (2005). A Brief History of Neoliberalism. Oxford, Oxford.

Hansard Society, (2001) The Challenge for Parliament: Making Government Accountable. London: Vacher Dod

Hawke, G. (1973). Between Governments and Banks. Wellington, Government Printer.

Hay, C. and D. Richards (2000). "The tangled webs of Westminster and the whitehall: the discourse, strategy and practice of networking within the British core executive." Public Administration 78(1).

Hay, C. (2004). "Theory, Stylized Heuristic or Self Fulfilling Prophecy? Status of Rational Choice Theory in Public Administration." Public Administration 82(1).

Henderson, A. (1990). The quest for efficiency : the origins of the State Services Commission. Wellington, State Service Commission.

Hicks, C. (2007). "A Case for Public Sector Ethics." Policy Quarterly 3(3): 11-15. 
Holland, M. and J. Boston, Eds. (1990). The Fourth Labour Government. Auckland, Oxford University Press.

Hood, C. (1990). Beyond the Public Bureaucracy State? Public Administration in the 1990s. London, London School of Economics.

Hood, J., O James \& C Scott (2000). "Regulation of Government: Has it Increased, is it Increasing, Should it be Diminished?" Public Administration 78(2): 283-304.

Hood, C. (2001). Public Service Bargain and Public Service Reform. Politicians, Bureaucrats and Administrative Reform. B. G. Peters and J. Pierre. London, Routledge.

Hood, C. and M. Lodge (2006). The Politics of Public Service Bargain. London, Oxford University Press.

Hornblow, A. and P. Barnett (2000). "A turbulent decade: lessons from the 'health reforms'." New Zealand Medical Journal 113(1108): 133-135.

Howden-Chapman, P. and T. Ashton (2000). "Public purchasing and private priorities for healthcare in New Zealand." Health Policy 54: 27-43.

Hummel, R. (1994). The Bureaucratic Experience: A Critique of Life in the Modern Organization. New York, St Martin Press.

Hunn, D. K. (2007). Investigation into the public service recruitment and employment of Ms Madeleine Setchell. Wellington, SSC.

Hunt, G. (2005). "Weight of Evidence". In New Zealand Listener. Apirl 30 - May 6 2005 198(3390).

Huxham, C. and S. Vangen (2005). Managing to Collaborate: The Theory and Practice of Collaborative Advantage. New York, Routeledge.

Jackson, K. (1978). A political scientist looks at parliament. The Reform of Parliament: Papers presented in memory of Dr Alan Robinson. S. J. Marshall. Wellington, New Zealand Institute of Public Administration.

Jackson, K. (1987). The Dilemma of Parliament. Wellington, Allen \& Unwin.

Jacobs, K., K. Jones, et al. (2007). Parliamentary Financial Oversight and Accountability in the Antipodes. Fifth Asia Pacific Interdisciplinary Research in Accounting, Auckland. 
James, C. (1997). Under New Sail: MMP and Public Servants. Wellington, Institute of Policy Studies.

James, C. (2001). "Left" and "Right": Speech to the Wellington Rotary Club.

James, C. (2002). The Ties that Binds. Wellington, Institute of Policy Studies \& the New Zealand Centre of Public Law.

Janiewski, D. and P. Morris (2005). New Rights New Zealand: Myths, Moralities and Markets. Auckland, Auckland University Press.

Johns, I. B. (1979). Efficiency in government : the changing role of the central administrative agencies 1962-78. Wellington, NZIPA.

Jones, K. and K. Jacobs (2005). Governing the Government: the Paradoxical Place of Public Accounts Committee. Australasian Study of Parliament Group Conference, Sydney.

Joseph, P. A. (2001). Constitutional and Administrative Law in New Zealand. Brookers, Wellington.

Keith, K. (2005). Development of the role of the Ombudsman with reference to the Pacific. 22nd Australiasian and Pacific Ombudsman Regional Conference, Parliament House, Wellington.

Kelly, P. (2005). Liberalism. London, Polity.

Kelsey, J. (1993). Rolling Back the State. Wellington, Bridget Williams Books.

Kelsey, J. (1995). The New Zealand Experiment: A World Model for Structural Adjustment? Auckland, Bridget Williams.

Kelsey, J. (2003). "The Denationalization of Money: Embedded Neo-Liberalism and the Risks of Implosion." Social \& Legal Studies 12(2).

Klijn, E. and C. Skelcher (2007). "Democracy and Governance Networks: Compatible or Not?" Public Administration 85(3): 587-608.

Kymlicka, W. (1989). Liberalism, Community and Culture. Oxford, Oxford University Press.

Kymlicka, W. (2001). Contemporary Political Philosophy: An Introduction. Oxford, Oxford University Press.

Labrum, B. (2004). Negotiating an Increasing Range of Functions: Families and the Welfare State. Past Judgment: Social Policy in New Zealand History. B. 
Dalley and M. Tennant. Dunedin, University of Otago Press.

Laing, R. (2006). Accounting and Accountability. ASPG Annual Conference "Parliamentary Control of the Executive: the People and the Money", Parliament, Wellington.

Laking, R. (2008). "Whose Duty." Public Sector 30(3).

Larner, W. (2000). "Neo-liberalism: Policy, Ideology, Governmentality." Studies in Political Economy 63: 5-26.

Larner, W. and T. Mayow (2003). "Strengthening Communities through Local Partnerships:. Building a collaborative research project." Journal of Social Policy 20(119-133).

Larner, W. and D. Craig (2005). "After Neoliberalism? Community Activism and Local Partnerships in Aotearoa New Zealand." Antipode 37(3): 404-424.

Leigh, E. (2003). Speech Writing: A Forgotten Art. Scoop.com. Wellington. 2008.

Levine, S. (1979). The New Zealand Political System: Politics in a Small Society. Auckland, Allen \& Unwin.

Lewis, K. (2007). "The Paradox of Managing for Outcomes." Policy Quarterly 3(3).

Leys, C. (2001). Market-driven Politics. Neoliberal Democracy and the Public Interest. London, Verso.

Lijphart, A. (1984). Democracies: Patterns of Majoritarian and Consensus Government in Twenty-one Centuries. New Haven, Yale University Press.

Lijphart, A. (1999). Patterns of Democracy. New Haven, Yale University Press.

Lipson, L. (1948). Politics of Equality: New Zealand's Adventure in Democracy. Chicago, University of Chicago Press.

Little, A. (2002). The Politics of Community. Edingburgh, Edingburgh University Press.

Lonti, Z. and R. Gregory (2007). "Accountability or Countability? Performance Measurement in the New Zealand Public Service." Australian Journal of Public Administration 66(4).

Lowndes, V. (2001). "Rescuing Aunt Sally: Taking Institutional Theory Seriously in Urban Politics." Urban Studies 38(11): 1953-71. 
Lucas, J. (1993). Responsibility. New York, Oxford University Press.

Lukes, S. (2004). Invasions of the Market. From Liberal Values to Democratic Transition. Essays in Honor of Janos Kis. Budapest, Central University Press.

Lynn, L. (2001). "The Myth of the Bureaucratic Paradigm: What Traditional Public Administration Really Stood for." Public Administration Review 61(2): 144160.

Lynn, L. (2006). Public Management: Old and New. London, Routledge.

Maharey, S. (2001). Values and politics: Some reflections on the new social democracy in a New Zealand context. Comments to a seminar hosted by the Foundation for Policy Initiatives, Rudd Watts \& Stone. Auckland.

Maharey, S. (2003). The Third Way and how I got onto it.

Majumdar, D. (2006). "Collaboration among government agencies with special reference to New Zealand: a literature review." Social Policy Journal of New Zealand.

Mallard, T. (2002). Opening of GOVIS conference. Wellington.

Mallard, T. (2002). Speech to the Public Service Senior Management Conference. Wellington.

Mallard, T. (2003). The New Zealand Story: Public Management Reform and Ethics, Values and Standards. Visit to Santiago, Republic of Chile.

Maor, M. (1999). "The paradox of managerialism." Public Administration Review $59(1)$.

Marshall, P. B. (1957). Professional Ethics and Discretion. Bureaucracy in New Zealand. R. S. Milne. Wellington, NZIPA.

Marshall, G. (1986). Constitutional Conventions: the rules and forms of political accountability. Oxford, Claredon Press.

Martin, J. (1988). A Profession of Statecraft? Three essays on some current issues in the New Zealand public service. Wellington, Institute of Policy Studies.

Mascarenhas, R. C. (2003). The New Zealand Public Service: national identity and international reform. Civil Service Systems in Anglo American 
Countries. J. Halligan. Cheltenham, Edward Elgar.

Matti, P. (2007). "Managerial and political accountability: the widening gap in the organisation of welfare." International Review of Administrative Sciences 73(3): 365-386.

May, L. (1996). The Socially Responsive Self: Social Theory and Professional Ethics. Chicago, University of Chicago Press.

McCarthy Commission (1962). The State Services in New Zealand: Report of the Royal Commission of Inquiry. Wellington, Government Printer.

McClure, M. (2004). A Badge of Poverty or a Symbol of Citizenship? Needs, Rights and Social Security, 1935 - 2000. Past Judgment: Social Policy in New Zealand History. B. Dalley and M. Tennant. Dunedin, University of Otago Press.

McGee, D. (2004). "Submission on Public Finance (State Sector Management) Bill."

McGee, D. (2005). Parliamentary Practices in New Zealand. Wellington, Government Printer.

McKinnon, M. (2003). Treasury: the New Zealand Treasury 1840 - 2000. Auckland, Auckland University Press.

McLean, J. (2005). New Public Management New Zealand Style. The Executive and Public Law: Power and Accountability in Comparative Perspective. A. Tomkins and P. Craig. Oxford, OUP: 124-160.

McLeay, E. (1995). The Cabinet and Political Power in New Zealand. Auckland, Oxford University Press.

McRae, T. (1994). A Parliament in Crisis: The Decline of Democracy in New Zealand. Wellington, Sheldaig Publications.

McRobie, A. (1978). Parliamentary "Control" on Public Expenditure. Politics in New Zealand. S. Levine. Auckland, George Allen and Unwin: 115-30.

Mercer, H. (1995). The Construction of the Competitive Order: The Hidden History of British Antitrust Policies. Cambridge, Cambridge University Press.

Merton, R. (1968). Social Theory and Social Structure. New York, Free Press.

Metin, A. (1977). Socialism without Doctrine. Sydney, Alternative Publishing Cooperative. 
Mill, J. S. (1962). Utilitarianism, Liberty and Representative Government. London, Dent \& Sons.

Millar, L. (2004). "Networking government: egovernment in New Zealand." Public Sector 27(4).

Milne, R. S. (1957). The Inevitability of Administrative Discretion. Bureaucracy in New Zealand. R. S. Milne. Wellington, NZIPA.

Moore, M. (1995). Creating Public Value. Cambridge, Harvard University Press.

Morrison, A. (1998). Traders in Information: The Public Interest and Policy Debate from a News Media Perspective. Public Service Senior Management Conference, Wellington, SSC.

Mosher, F. (1982). Democracy and the Public Service. New York, Oxford University Press.

Mowbray, M. (2005). "Community capacity building or state opportunism." Community Development Journal 40(3): 255-264.

MSD (2002). Mosaics: Whakaahua Papariki: Key Findings and Good Practice Guide for Regional Co-ordination and Integrated Service Delivery. Wellington, MSD.

Mulgan, R. (1992). The Elective Dictatorship in New Zealand. New Zealand Politics in Perspective. H. Gold. Auckland, Longman Paul.

Mulgan, R. (1992). "The Principles of Rogerpolitics." Public Sector 15(1): 16-17.

Mulgan, R. (1997a). Contracting Out and Accountability. Discussion Paper 51: Graduate Public Policy Programme. Canberra, ANU.

Mulgan, R. (1997b). Politics in New Zealand. Auckland, Auckland University Press.

Mulgan, R. (1998). Politicising the Australian Public Service. Research Paper No.3. Canberra, Parliamentary Library.

Mulgan, R. (1999). Have New Zealand's Political Experiments Increased Accountability? Discussion Paper 59: ANU Public Policy Programme. Canberra, ANU.

Mulgan, R. (2000). Accountability: An Ever-Expanding Concept? Discussion Paper: ANU Public Policy Programme. Canberra, Australian National 
University.

Mulgan, R. (2002). "On Ministerial Resignations (and the Lack Thereof)." Australian Journal of Public Administration 61(1): 121-127.

Mulgan, R. (2003). "One Cheer for Hierarchy - Accountability in Disjointed Governance." Political Science 55(2).

Mulgan, R. (2004). Public Sector Reform in New Zealand: Issues of Public Accountability. Discussion Paper 04-03. Canberra, Australian National University.

Mulgan, R. (2005). Government accountability for outsourced services. Working Papers. Canberra, Australian National University.

Mulgan, R. (2006). Truth in Government and the Politicisation of Public Service Advice. Discussion Papers. Canberra, Australian National University.

Nagel, J. H. (1998). "Social Choice in a Pluralitarian Democracy: the Politics of Market Liberalization in New Zealand." British Journal of Political Studies 28.

Narveson, J. (1987). The Libertarian Idea. Philadelphia, Temple University Press.

Navarro, V. (2002). "A Critique of Social Capital." International Journal of Health Services 32(3): 423-432.

Negrine, R., C. Holtz-Bacha, et al. (2007). Professionalisation of Political Communication, Intellect Ltd.

Neustadt, R. (1990). Presidential Power and the Modern Presidents: The Politics of Leadership from Roosevelt to Reagan. New York, Free Press.

Newberry, S. (2002). New Zealand's Public Sector Financial Management System: Financial Erosions in the Government Departments. Christchurch, University of Canterbury.

Newberry, S. and J. Pallot (2003). "Fiscal (ir)responsibility: privileging PPPs in New Zealand." Accounting, Auditing \& Accountability 16(3): 467-492.

Newberry, S. and J. Pallot (2004). "Freedom or Coercion: NPM incentives in New Zealand Central Government Departments." Management Accounting Research 15 (2004): 247-266.

Newberry, S. and J. Pallot (2005). "A Wolf in Sheep's Clothing? Wider Consequences of the Financial Management System of the New Zealand 
Central Government." Financial Accountability \& Management 21: 263-277.

Newberry, S. and J. Pallot (2006). "New Zealand's Financial Management

System: Implications for Democracy." Public Money and

Management(September 2006).

Norman, R. (2002). "Managing Through Measurement or Meaning: Lessons from Experience with New Zealand's Public Sector Performance Management systems." International Review of Administrative Sciences 68(4): 619-628.

Norman, R. (2003). Obedient Servants? Management Freedoms and Accountabilities in the New Zealand Public Sector. Wellington, VUP.

OAG (2002). Severance Payments in the Public Sector. Wellington, Office of the Auditor-General.

Olsen, M. (2006). "Maybe it is time to rediscover bureaucracy?" Journal of Public Administration Research and Theory 16(1).

Olssen, E. (1992). Towards a New Society. The Oxford History of New Zealand. G. Rice. Auckland, Oxford University Press.

Outhwaites, W. (2006). The Future of Society. Oxford, Blackwell.

Ovenden, K. (1980). Commentary on "Administration and the Changing Constitution". State Servants and the Public in the 1980s. R. M. Alley. Wellington, NZIPA.

Pallot, J. (2003). "A wider accountability: the Audit Office and New Zealand's Bureaucratic Revolution." Critical Perspectives on Accounting 14: 133-155.

Palmer, G. (1987). Unbridled Power. Auckland, OUP.

Palmer, G. and M. Palmer (2004). Bridled Power. Auckland, OUP.

Papadopoulos, Y. (2007). "Problems of Democratic Accountability in Network and Multilevel Governance." European Law Journal 13(4): 469-486.

Pathfinder (2003). Building Block 3: Intervention Logic. Guidance on Outcome Focused Management. Wellington, SSC.

Peck, J. and A. Tickell (2002). Neoliberalizing Space. Spaces of Neoliberalism: Urban Restructuring in North America and Western Europe. N. B. N. Theodore. London, Blackwell Publishing. 34: 388-404.

Petrie, M. (1998). Organisational Transformation: the Income Support 
Experience. Wellington, Department of Social Welfare.

Petrie, M. and D. Webber (2001). Review of Evidence on Broad Outcome of Public Sector Management Regime. Wellington, Treasury.

Polaschek, R. J. (1958). Government Administration in New Zealand. Wellington, New Zealand Institute of Public Administration.

Polidano, C. (1999). "The bureaucrat who fell under a bus." Governance 12(2): 201-209.

Polidano, C. (2000). "The Bureaucrats who Almost Fell Under a Bus: a Reassertion of Ministerial Responsibility?" Political Quarterly 71(2): 177183.

Polidano, C. (2001). "An Exocet in a Red Box: Parliamentary Accountability in the Sandline Affair." Public Administration 79(2): 249-275.

Pollit, C. (2003). The essential public manager. Maidenhead, Open University Press.

Pollitt, C. (1993). Managerialism and the Public Services: Cuts or Cultural Change in the 1990s. Oxford, Blackwell.

Pollitt, C. and G. Bouckaert (2004). Public Management Reform: A Comparative Analysis. Oxford, Oxford University Press.

Power, M. (1994). The Audit Explosion. London, Demos.

Power, M. (2003). "Evaluating the Audit Explosion." Law \& Policy 25(3).

Probine, M. (1963). "The Public Service and Ministers: State Services Commission Management Leaflet No.6." Public Sector (December 1963).

Provan, K. and H. Milward (2000). "Governing the Hollow State." Journal of Public Administration Research and Theory 10(2): 359-79.

Putnam, R. (2000). Bowling alone: the collapse and revival of American Community. New York, Simon Schuster.

Rawls, J. (2005). Political Liberalism. New York, Columbia University Press.

Rhodes, R. A. W. (1997). Understanding Governance. Buckingham, Open University Press. 
Rhodes, R. A. W. (2000). Governance and Public Administration. Debating Governance. J. Pier. Oxford, Oxford University Press.

Rhodes, R. A. W. (2005). Is Westminster dead in Westminster. Inaugural lecture in the ANZSOG-ANU Public Lecture series, The Shine Dome, Academy of Science, Canberra.

Rhodes, R. A. W. and P. Weller (2005). Westminster transplanted and Westminster implanted: exploring political change. Westminster Legacies: Democracy and Responsible Government in Asian and Pacific. H. Patapan, J. Wanna and P. Weller. Sydney, UNSW Press.

Rhodes, R. A. W. and J. Wanna (2007). "The Limits to Public Value, or Rescuing Responsible Government from the Platonic Guardians." Australian Journal of Public Administration 66(4): 406-421.

Rhodes, R. A. W. (2007). "Understanding Governance: Ten Years On." Organization Studies 28(8): 1243-1264.

Rice, G. (1992). A Revolution in Social Policy:1981-1991. Oxford History of New Zealand. G. Rice. Auckland, Oxford University Press.

Richardson, R. (1990). Statement by the Minister of Finance. Economic and Social Initiatives: Statements to the House of Representatives. J Bolger, R. Richardson and W. Birch. Wellington.

Roberts, A. (2000). "Less Government, More Secrecy: Reinvention and the Weakening of Freedom of Information Law'." Public Administration Review 60(4): 308-320.

Roberts, A. (2001). "Structural Pluralism and the Right to Information." University of Toronto Law Journal 51(3): 243-271.

Roberts, J. M. (2004). "What's Social About Social Capital?" British Journal of Politics and International Relations 6: 471-493.

Robinson, S. E. (2006). "A Decade of Treating Networks Seriously." Policy Studies Journal 34(4).

Robson, J. (1987). Sacred Cows and Rogue Elephants:. Policy Development in the New. Zealand Justice Department. Wellington, Government Printer.

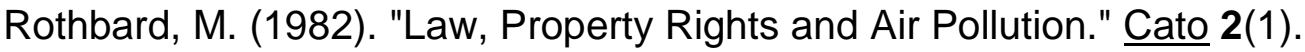

Rothstein, B. and E. Uslaner (2005). "All for one: Equality, Corruption and Social Trust." World Politics 58(1): 41-72. 
Rudd, C. (2001). The Welfare State. The Political Economy of New Zealand. C. Rudd and B. Roper. Auckland, Oxford University Press.

Russell, N. and R. Gregory (2005). "Making the Undoable Doable." American Review of Public Administration 35(4).

Ryan, A. (1974). J S Mill. London, Routledge.

Ryan, B. (2003a). "Hard Yards Ahead: the Second Stage of Public Sector Reform in New Zealand." International Review of Public Administration 8(1): 39-51.

Ryan, B. (2003b). From Technocracy to Learning: Analysing and Evaluating in the 21st Century. Social Policy Research and Evaluation Conference, Ministry of Social Development, Wellington.

Ryan, B. (2004). Learning MfO. Queensland, Institute of Public Administration.

Ryan, B. (2006a). "Managing for Outcomes: Understanding Clients." Policy Quarterly 2(4).

Ryan, B. (2006b). "Beyond Westminster: Thinking the Aotearoa/New Zealand Way of Governing." Policy Quarterly 2(3).

Ryan, B. (2008). Constitutional adaptation in practice: Emerging realities in 21st century governing in Aotearoa/New Zealand? After the Reforms: Where are we? Where are we going, Wellington, 28-29 February 2008.

Saunders, B. (2008). State Sector Neutrality. Dominion Post. Wellington.

Savoie, D. J. (2003). Breaking the Bargain: Public Servants, Ministers, and Parliament. Toronto, University of Toronto Press.

Schick, A. (1996). The Spirit of Reform: Managing the New Zealand State Sector in a Time of Change. Wellington, SSC/Treasury.

Schick, A. (2001). Reflections on Public Management Reform: Do New Zealand's Current Opportunities and Strategies Differ Markedly From Those of the Late 1980s? Wellington, Treasury.

Scott, K. J. (1962). The New Zealand Constitution. London, Oxford at the Claredon Press.

Scott, G. (1996). Government Reform in New Zealand. Washington, International Monetary Fund. 
Scott, G. (2001). Public Management in New Zealand: Lesson and Challenges. Wellington, NZBR.

Scott, G. (2008). After the Reforms: Some Questions about the State of the State in New Zealand. After the Reforms, Wellington.

Selznick, P. (1949). TVA and the Grass Roots: A Study of Politics and Organization. Berkeley, University of California Press.

Sementelli, A. and C. F. Abel (2003). Unmaking the Disciplinary Matrix: Deconstructing Public Administration Ideologies. 16th Annual Public Administration Theory Network Conference, Anchorage: Alaska.

Shaw, R. (1999). Rehabilitating the Public Service - Alternatives to the Wellington Model. The New Politics: a Third Way for New Zealand. S Chatterjee et al. Palmerston North, Dunmore Press.

Shepherd, R. (1986). "Is the Age of Civil Service Neutrality Over?" Public Administration 65(Spring): 69-78.

Simpson, T. (1984). A Vision Betrayed. Auckland, Hodder Stoughton.

Sinclair, K. (1963). The historian as prophet: Equality, inequality and civilization. 2007.

Sinclair, K. (2000). A History of New Zealand. Auckland, Penguin Book.

Singleton, J., A Grimes, et al. (2006). Innovation + Independence: The Reserve Bank of New Zealand, 1973-2002. Auckland, University of Auckland Press.

Skene, G. (1990). New Zealand Parliamentary Committees: An Analysis for the Institute of Policy Studies. Wellington, IPS.

Smith, T. (1974). The New Zealand Bureaucrat. Wellington, Cheshire Publishing.

Smith, M. K. (2001). "Peter Senge and the learning organization." The Encyclopedia of Information Education.

Smith, D. (2005). Clarifying the doctrine of ministerial responsibility as it applies to the government and parliament of Canada. Commission of Inquiry into Sponsorship Program \& Advertising Activities: Volume 1: Parliament, Ministers and Deputy Ministers. Ottawa.

Sossin, L. (2005). Defining boundaries: the Constitutional Argument for Bureaucratic Independence and its Implications for the Accountability of the 
Public Service. Commission of Inquiry into Sponsorship Program \& Advertising Activities: Volume 2: The Public Service and Transparency. Ottawa.

Sparks, C. (2003). "Liberalism, Terrorism and the Politics of Fear." Politics 23(3): 200-206.

Spicer, B., D. Emanuel, et al. (1997). Transforming Government Enterprises: Managing Radical Organisational Change in Deregulated Environments. CIS Policy Monographs. Wellington, Centre for Independent Studies.

Spicer, M. (2007). "Politics and the Limits of a Science of Governance: Some Reflections on the Thought of Bernard Crick." Public Administration Review(July/August): 768-778.

SSC (1999). Improving Accountability: Setting the Scene. Occasional Paper No.10. Wellington, SSC.

SSC (2003). Political Neutrality Fact Sheet No.3. Wellington.

SSC and Treasury (2003). Managing for Outcomes: Guidance for Departments. Wellington, SSC.

SSC (2005a). New Zealand Public Service Code of Conduct. Wellington.

SSC and Treasury (2005). Guidance and Requirements for Departments: Preparing the Statement of Intent. Wellington.

SSC (2005b). Getting Better at Managing for Outcomes - self assessment tool. Wellington.

SSC (2007a). Standards of Integrity \& Conduct. Wellington.

SSC (2007b). Understanding the code of conduct - Guidance for State Servants. Wellington.

SSC (2007c). State Services Commissioner's Report on the Public Service recruitment and employment of Ms Madeleine Setchell. Wellington, State Service Commission.

SSC (2008). Political Neutrality Fact Sheet No.1. Wellington.

Stoker, G. (2006). Why Politics Matters: Making Democracy Work. London, Palgrave MacMillan.

Stone, B. (1995). "Administrative Accountability in the 'Westminster' 
Democracies: Towards a New Conceptual Framework." Governance 8(4): 505-526.

Szreter, S. (2002). "The State of Social Capital: Bringing back in power, politics and history." Theory and Society 31: 573-621.

Taggart, M. (2004). "From Parliamentary Powers to Privatization: The Chequered History of Delegated Legislation in the Twentieth Century." University of Toronto Law Journal 55(3).

Tanner, R. (2007). "Issues and Principles." Public Sector 30(3).

Taylor, C. (1985). Philosophy and the Human Sciences: Philosophical Papers 2. Cambridge, Cambridge University Press.

Thomas, P. (2007). Why is Performance-base Accountability so Popular in Theory and so Difficult in Practice. International Conference on Government Performance Management, Taiwan, Department of Public Administration, National Chengchi University.

Thomson, D. (1998). A World without Welfare. Auckland, Auckland University Press with Bridget Williams Books.

Tomkins, A. (1996). "A right to mislead government?" Legal Studies(16): 63-83.

Tomkins, A. (1998). Constitution After Scott: Government Unwrapped. Oxford, Oxford University Press.

Tomkins, A. (2002). "In Defence of the Political Constitution." Oxford Journal of Legal Studies 22(1): 157 - 175.

Tomkins, A. (2003a). What is Parliament for. Public Law in a Multilayered Constitution. N. Bamforth and P. Leyland. Oxford, Hart Publishing.

Tomkins, A. (2003b). Public Law. Oxford, Oxford University Press.

Tomkins, A. (2005). Our Republican Constitution. Oxford, Hart Publishing.

Treasury (1984). Economic Management. Wellington.

Treasury (1987). Government Management. Wellington, Government Printer.

Treasury (1996). Putting it together: An Explanatory Guide to the New Zealand Public Sector Financial Management System. Wellington, Treasury.

Treasury and SSC (2007). Performance information measures and standards in 
the SOI and Annual Report. Wellington, Treasury/SSC.

Turner, C. (1994). Modernity and Politics in the Work of Max Weber. London, Routledge.

Uhr, J. (2005a). Ministerial Responsibility in Australia: 2005. 2005 Constitutional Law Conference, UNSW Sydney.

Uhr, J. (2005b). Terms of Trust: Arguments over Ethics in Australian Government. Sydney, UNSW Press.

van Thiel, S. and F. L. Leeuw (2002). "The Performance Paradox in the Public Sector." Public Performance and Management Review 25(3).

Vass, P. and I. Bartle (2007). "Self regulation within the regulatory state: Towards a new regulatory paradigm." Public Administration 85(3).

Verhoest, K., G. Bouckaert, et al. (2007). "Janus-faced reorganization: specialization and coordination in four OECD countries in the period 1980 2005." International Review of Administrative Sciences 73(325).

Waldron, J. (2003). "Security and Liberty: The Image of Balance." The Journal of Political Philosophy 11(2): 191-210.

Walker, A. (2004). Overcoming the Neoliberal Legacy: The importance of trust for improved interagency collaborative working in New Zealand. Strengthening Communities through Local Partnerships Research Paper 14. Auckland, Auckland University.

Wanna, J. (2005). New Zealand's Westminster trajectory: Archetypal transplant to maverick outlier. Westminster Legacies: Democracy and Responsible Government in Asian and the Pacific. H. Patapan, J. Wanna and P. Weller. Sydney, UNSW Press.

Warner, B. (2001). "J S Mill's Theory of Bureaucracy within Representative Government." Public Administration Review 61(4).

Watson, M. (2002). "The institutional paradox of monetary orthodox: reflection on the political economy of central bank independence." Review of International Political Economy 9(1): 183-196.

Watson, M. (2003). "The Politics of Inflation Management." Political Quarterly 74(3): 285-297.

Webb, L. (1940). Government in New Zealand. Wellington, Department of Internal Affairs. 
Webber, D. (2004). "Wrestling with Outcomes: the New Zealand Experience." Agenda 11(4): 2004.

Weber, M. (1947). From Max Weber. London, Kegan Paul, Trench, Trubner \& Co.

Weber, M. (1978). Economy and Society: An Outline of Interpretive Sociology. Berkeley, University of California Press.

Weeks, J. (1995). Invented Moralities: Sexual Values in an Age of Uncertainty. New York, Columbia University Press.

Weeks, J. (2000). Making Sexual History. Cambridge, Polity Press.

Weller, P. (2003). The Australian Public Service: Still Anonymous, Neutral and a Career Service? Papers on Parliament. Canberra, Department of the Senate. $\mathbf{4 0 .}$

White, N. (2007). Free and Frank: Making the Official Information Act 1982 Work Better. Wellington, Institute of Policy Studies.

Whitehead, J. (2008). Continuity and Change: the Ongoing Pursuit of State Sector Performance. After the Reforms, Wellington, 28-29 April.

Wilenski, P. (1980). Has the Career Service a Future? State Servants and the Public in the 1980s. R. M. Alley. Wellington, NZIPA.

Wilson, J. Q. (1989). Bureaucracy: What Government Agencies Do and Why They Do It. New York, Basic Books.

Wolff, J. (1998). John Rawls: Liberal Democracy Restated. Liberal Democracy and its Critics. A. Carter and G. Stokes. Cambridge, Polite Press.

Woodhouse, D. (1994). Ministers and Parliament: Accountability in Theory and Practice. Oxford, Claredon Press.

Woodhouse, D. (1997). In pursuit of good administration : ministers, civil servants, and judges. Oxford, Claredon Press.

Woodhouse, D. (2002). "The Reconstruction of Constitutional Accountability." Public Law Spring(73-90).

Woodhouse, D. (2004). "UK Ministerial Responsibility in 2002: the tale of two resignations." Public Administration 82(1). 
Woodhouse, D. (2005). Changing patterns of accountability in Westminster systems: a UK perspective. ANU Political Science Programme. Canberra, ANU.

World Bank (2000). Reforming Public Institutions and Strengthening Governance. Washington DC, World Bank.

Zakaras, A. (2007). John Stuart Mill, Individuality, and Participatory Democracy. $\underline{J}$ S Mill's Political Thought. N. Urbinati and A. Zakaras. Cambridge, Cambridge University Press.

Zifcak, S. (2001). "Contractualism, Democracy and Ethics." Australian Journal of Public Administration 60(2): 86-98. 